\title{
Ocena zgodności z Konstytucją przepisów ustawy o inwestycjach w zakresie elektrowni wiatrowych ${ }^{1}$
}

\begin{abstract}
Assessment of conformity to the Constitution of provisions of the Act on Investment in the Field of Wind Farms: The provisions reviewed by the Constitutional Tribunal concern the location of wind farms in Poland. The applications of a group of Deputies contained concerns regarding, inter alia, the distance between wind turbines and residential buildings, as well as the impact of these facilities on natural environment. According to opinion, the location of the power plant only on the basis of a spatial development plan does conform to the Constitution. Before the act came into force, the construction of a wind farm could also take place in an area uncovered by the spatial development plan. On the other hand, provisions regarding cancellation of initiated or unfinished proceedings regarding a decision on development conditions relating conform to the Constitution.
\end{abstract}

Keywords: Sejm, investments, wind farms, draft position

Słowa kluczowe: Sejm, inwestycje, farmy wiatrowe, projekt stanowiska

Doktor nauk prawnych, Uniwersytet Warszawski, ekspert ds. legislacji BAS • z.gromek@wpia.uw.edu.pl . https://orcid.org/0000-0003-1873-1998

Na podstawie art. 69 ust. 2 w związku z art. 42 pkt 3 ustawy z dnia 30 listopada 2016 r. o organizacji i trybie postępowania przed Trybunałem Konstytucyjnym (Dz. U. poz. 2072, ze zm.), w imieniu Sejmu Rzeczypospolitej Polskiej przedkładam wyjaśnienia w sprawie wniosku grupy posłów z 2 grudnia 2016 r. (sygn. akt K 51/16) oraz wniosku grupy posłów z 19 grudnia 2016 r. (sygn. akt K 54/16), połączonych do wspólnego rozpatrzenia pod sygn. akt $\mathrm{K}$ 51/16, jednocześnie wnosząc o stwierdzenie, że:

- art. 3 ustawy z dnia 20 maja 2016 r. o inwestycjach w zakresie elektrowni wiatrowych (Dz. U. poz. 961, ze zm.) nie jest niezgodny z art. 22, art. 31 ust. 3 i art. 32 ust. 1 Konstytucji,

$1 \quad$ Projekt stanowiska Sejmu w sprawie zgodności $z$ Konstytucja przepisów ustawy z dnia 20 maja 2016 r. o inwestycjach $w$ zakresie elektrowni wiatrowych (sygn. akt K 51/16) sporządzony 13 marca 2019 r.; BAS-WAKU 2702/16. 
- art. 4 ust. 1, art. 6 i art. 7 ustawy powołanej w pkt 1:

- są zgodne z zasadą proporcjonalności wywodzoną z art. 2 Konstytucji, zasadą zrównoważonego rozwoju wywodzoną z art. 5 Konstytucji oraz z art. 31 ust. 3, art. 32 ust. 1-2 i art. 64 ust. 1-3 Konstytucji,

- nie są niezgodne $z$ art. 20 i art. 22 Konstytucji,

- art. 4 ust. 1, art. 6 i art. 15 ust. 8-9 ustawy powołanej w pkt 1 są zgodne z zasadą proporcjonalności wywodzoną $\mathrm{z}$ art. 2 Konstytucji, a także $\mathrm{z}$ art. 16 ust. 2 i art. 165 ust. 1-2 Konstytucji,

- art. 14 ust. 5-6, art. 15 ust. 3, ust. 8 i ust. 9 ustawy powołanej w pkt 1:

- są zgodne z zasadą ochrony zaufania obywatela do państwa, zasadą ochrony praw nabytych i zasadą ochrony interesów w toku, wywodzonych $\mathrm{z}$ art. 2 Konstytucji, zasadą zrównoważonego rozwoju, wywodzoną $\mathrm{z}$ art. 5 Konstytucji, art. 32 ust. 1 i art. 64 Konstytucji,

- nie są niezgodne $z$ art. 20 i art. 22 Konstytucji,

- art. 14 ust. 5-6 ustawy powołanej w pkt 1 jest zgodny z art. 10 Konstytucji.

W pozostałym zakresie, na podstawie art. 59 ust. 1 pkt 2 ustawy o organizacji i trybie postępowania przed Trybunałem Konstytucyjnym, wnoszę o umorzenie postępowania ze względu na niedopuszczalność wydania wyroku.

\section{Uzasadnienie}

\section{Przedmiot kontroli}

1. Wnioskiem z 2 grudnia 2016 r. grupa posłów (dalej: Wnioskodawca I), reprezentowana przez posła Stanisława Gawłowskiego, wystąpiła do Trybunału Konstytucyjnego w sprawie zgodności z Konstytucją przepisów ustawy z dnia 20 maja 2016 r. o inwestycjach w zakresie elektrowni wiatrowych (Dz. U. poz. 961, ze zm.; dalej: ustawa o inwestycjach lub ustawa). Wniosek ten (dalej: wniosek I) został zarejestrowany pod sygn. akt K 51/16. Następnie we wniosku z 19 grudnia 2016 r. inna grupa posłów (dalej Wnioskodawca II), reprezentowana przez posłów Michała Stasińskiego, Mieczysława Kasprzaka oraz Kamilę Gasiuk-Pihowicz, wystąpiła o kontrolę zgodności z Konstytucją przepisów tej samej ustawy (dalej: wniosek II, pierwotnie oznaczony sygn. akt K 54/16).

Zarządzeniem Prezesa Trybunału Konstytucyjnego powyższe wnioski zostały połączone w celu łącznego rozpoznania pod sygn. akt K 51/16, z uwagi na tożsamość przedmiotu sprawy.

2. Zgodnie z petitum wniosku I, przedmiot kontroli stanowią: art. 4 ust. 1-2, art. 5, art. 6, art. 9 pkt 1, art. 12, art. 13 ust. 2 i ust. 6, art. 14 ust. 5-7, art. 15 ust. 3, ust. 7 pkt 2, ust. 8-9 oraz art. 17 ustawy o inwestycjach. Z kolei, w świetle petitum wniosku II, przedmiot kontroli stanowią: art. 3, art. 4, art. 5, art. 6, art. 7, art. 12, art. 13 ust. 2 i ust. 6 i art. 14 ustawy o inwestycjach oraz art. 3 pkt 3, art. 82 ust. 3 
pkt 5 ustawy z dnia 7 lipca 1994 r. - Prawo budowlane (t.j. Dz. U. 2018, poz. 1202, ze zm.; dalej: prawo budowlane) i wiersz XXIX tabeli stanowiącej załącznik do tej ustawy. Ponadto Wnioskodawca II wystąpił o stwierdzenie niezgodności z Konstytucją ustawy o inwestycjach w całości.

3. Kwestionowane przepisy ustawy o inwestycjach, zgodnie ze stanem prawnym właściwym w dacie wystąpienia $\mathrm{z}$ wnioskami, mają następujące brzmienie:

- art. 3 „Lokalizacja elektrowni wiatrowej następuje wyłącznie na podstawie miejscowego planu zagospodarowania przestrzennego, o którym mowa w art. 4 ust. 1 ustawy z dnia 27 marca 2003 r. o planowaniu i zagospodarowaniu przestrzennym, zwanego dalej "planem miejscowym»",

- art. 4 „1. Odległość, w której mogą być lokalizowane i budowane:

1) elektrownia wiatrowa - od budynku mieszkalnego albo budynku o funkcji mieszanej, w skład której wchodzi funkcja mieszkaniowa, oraz

2) budynek mieszkalny albo budynek o funkcji mieszanej, w skład której wchodzi funkcja mieszkaniowa - od elektrowni wiatrowej

- jest równa lub większa od dziesięciokrotności wysokości elektrowni wiatrowej mierzonej od poziomu gruntu do najwyższego punktu budowli, wliczając elementy techniczne, w szczególności wirnik wraz z łopatami (całkowita wysokość elektrowni wiatrowej).

2. Odległość, o której mowa w ust. 1, wymagana jest również przy lokalizacji i budowie elektrowni wiatrowej od form ochrony przyrody, o których mowa w art. 6 ust. 1 pkt 1-3 i 5 ustawy z dnia 16 kwietnia 2004 r. o ochronie przyrody, oraz od leśnych kompleksów promocyjnych, o których mowa w art. 13b ust. 1 ustawy z dnia 28 września 1991 r. o lasach, przy czym ustanawianie tych form ochrony przyrody oraz leśnych kompleksów promocyjnych nie wymaga zachowania odległości, o której mowa w ust. 1.

3. Odległość, o której mowa w ust. 1, nie jest wymagana przy przebudowie, nadbudowie, rozbudowie, remoncie, montażu lub odbudowie budynku mieszkalnego albo budynku o funkcji mieszanej, w skład której wchodzi funkcja mieszkaniowa”,

- art. 5 „1. Przez odległość, o której mowa w art. 4 ust. 1, rozumie się najkrótszy odcinek pomiędzy:

1) rzutem poziomym istniejącego budynku mieszkalnego albo istniejącego budynku o funkcji mieszanej, w skład której wchodzi funkcja mieszkaniowa, albo

2) granicą terenu objętego decyzją o warunkach zabudowy, o której mowa w art. 4 ust. 2 pkt 2 i w art. 59 ust. 1 ustawy z dnia 27 marca 2003 r. o planowaniu i zagospodarowaniu przestrzennym, zwaną dalej «decyzją WZ», dotyczącą inwestycji, o której mowa w pkt 1, na którym możliwa jest lokalizacja tej inwestycji, albo

3) linią rozgraniczającą teren, którego sposób zagospodarowania określony w planie miejscowym dopuszcza realizację inwestycji, o której mowa w pkt 1 , 
4) okręgiem, którego promień jest równy połowie średnicy wirnika wraz z łopatami, a środek jest środkiem okręgu opisanego na obrysie wieży istniejącej elektrowni wiatrowej, albo

5) linią rozgraniczającą teren, którego sposób zagospodarowania określony w planie miejscowym dopuszcza budowę elektrowni wiatrowej.

2. Przez obiekty budowlane, o których mowa w ust. 1 pkt 1 i 4, rozumie się również obiekty budowlane objęte decyzją o pozwoleniu na budowę albo zgłoszeniem, wobec którego organ administracji architektoniczno-budowlanej nie wniósł sprzeciwu.

3. Przez odległość, o której mowa w art. 4 ust. 2, rozumie się najkrótszy odcinek łączący punkt na granicy obszaru, dla którego ustanowiono formę ochrony przyrody, o której mowa w art. 6 ust. 1 pkt 1-3 i 5 ustawy z dnia 16 kwietnia 2004 r. o ochronie przyrody, lub leśnego kompleksu promocyjnego, o którym mowa w art. 13b ust. 1 ustawy z dnia 28 września 1991 r. o lasach, i odpowiednio: okrąg albo linię, o których mowa w ust. 1 pkt 4 i 5. Przepis ust. 2 stosuje się”,

- art. 6 „Odległość określoną zgodnie z art. 4 uwzględniają:

1) organy gminy - przy sporządzaniu oraz uchwalaniu studium uwarunkowań i kierunków zagospodarowania przestrzennego gminy albo jego zmiany;

2) organy gminy oraz wojewoda - przy sporządzaniu oraz uchwalaniu albo przyjmowaniu planu miejscowego albo jego zmiany;

3) organy gminy i wojewoda - przy wydawaniu decyzji o warunkach zabudowy;

4) organy administracji architektoniczno-budowlanej - przy wydawaniu pozwolenia na budowę oraz ocenie zasadności wniesienia sprzeciwu wobec zgłoszenia;

5) organy związku metropolitalnego - przy sporządzaniu oraz uchwalaniu studium ramowego uwarunkowań i kierunków zagospodarowania przestrzennego związku metropolitalnego albo jego zmiany;

6) organy województwa - przy sporządzaniu oraz uchwalaniu planu zagospodarowania przestrzennego województwa albo jego zmiany;

7) organy wydające decyzje o środowiskowych uwarunkowaniach - przy wydawaniu tych decyzji”,

- art. 7 „1. Plan miejscowy przewidujący lokalizację elektrowni wiatrowej:

1) określa maksymalną całkowitą wysokość elektrowni wiatrowej;

2) sporządza się co najmniej dla obszaru, na którym, zgodnie z art. 4 ust. 1, nie mogą być zlokalizowane nowe budynki mieszkalne albo budynki o funkcji mieszanej, w skład której wchodzi funkcja mieszkaniowa, a którego granice są wyznaczane z uwzględnieniem maksymalnej całkowitej wysokości elektrowni wiatrowej określonej w tym planie.

2. W uzasadnieniu dołączanym do projektu uchwały w sprawie przystąpienia do sporządzania planu miejscowego przewidującego lokalizację elektrowni wiatrowej zamieszcza się w szczególności maksymalną całkowitą wysokość elektrowni wiatrowej, która zostanie określona w tym planie”, 
- art. 9 „W ustawie z dnia 7 lipca 1994 r. - Prawo budowlane (Dz. U. z 2016 r. poz. 290) wprowadza się następujące zmiany:

1) w art. 3 pkt 3 otrzymuje brzmienie:

«3) budowli - należy przez to rozumieć każdy obiekt budowlany niebędący budynkiem lub obiektem małej architektury, jak: obiekty liniowe, lotniska, mosty, wiadukty, estakady, tunele, przepusty, sieci techniczne, wolno stojące maszty antenowe, wolno stojące trwale związane $\mathrm{z}$ gruntem tablice reklamowe i urządzenia reklamowe, budowle ziemne, obronne (fortyfikacje), ochronne, hydrotechniczne, zbiorniki, wolno stojące instalacje przemysłowe lub urządzenia techniczne, oczyszczalnie ścieków, składowiska odpadów, stacje uzdatniania wody, konstrukcje oporowe, nadziemne i podziemne przejścia dla pieszych, sieci uzbrojenia terenu, budowle sportowe, cmentarze, pomniki, a także części budowlane urządzeń technicznych (kotłów, pieców przemysłowych, elektrowni jądrowych i innych urządzeń) oraz fundamenty pod maszyny i urządzenia, jako odrębne pod względem technicznym części przedmiotów składających się na całość użytkową»",

- art. 12 „W przypadku elektrowni wiatrowych użytkowanych w dniu wejścia w życie ustawy, niespełniających wymogów określonych w art. 4, dopuszcza się jedynie przeprowadzenie remontu oraz wykonywanie innych czynności niezbędnych do prawidłowego użytkowania elektrowni, z wyłączeniem działań prowadzących do zwiększenia parametrów użytkowych elektrowni lub zwiększenia jej oddziaływań na środowisko",

- art. $13[\ldots]$

„2. Pozwolenia na budowę dotyczące elektrowni wiatrowych, wydane przed dniem wejścia w życie ustawy oraz wydane na podstawie postępowania, o którym mowa w ust. 3, zachowują moc, o ile w ciągu 3 lat od dnia wejścia w życie ustawy wydana zostanie decyzja o pozwoleniu na użytkowanie" [...];

„6. Wojewódzki inspektor nadzoru budowlanego nakazuje rozbiórkę wybudowanej części obiektu budowlanego, w przypadku nieuzyskania decyzji o pozwoleniu na użytkowanie, o której mowa w ust. 2, na koszt inwestora, chyba że inwestor uzyska - w terminie roku od dnia utraty mocy pozwolenia na budowę nowe pozwolenie na budowę dotyczące tej elektrowni”,

- art. 14 „1. Postępowania w przedmiocie wydania decyzji WZ, dotyczące budynku mieszkalnego albo budynku o funkcji mieszanej, w skład której wchodzi funkcja mieszkaniowa, wszczęte i niezakończone do dnia wejścia w życie ustawy prowadzi się przez 36 miesięcy od dnia wejścia w życie ustawy na podstawie przepisów dotychczasowych.

2. Postępowania w przedmiocie wydania decyzji WZ, dotyczące budynku mieszkalnego albo budynku o funkcji mieszanej, w skład której wchodzi funkcja mieszkaniowa, wszczęte po dniu wejścia w życie ustawy prowadzi się na podstawie przepisów dotychczasowych przez 36 miesięcy od dnia wejścia w życie ustawy. 
3. W przypadku decyzji WZ wydanej na podstawie postępowań, o których mowa w ust. 1 i 2, przesłanki odmowy przez organ administracji architektoniczno-budowlanej wydania pozwolenia na budowę lub, w przypadku zgłoszenia, wniesienia sprzeciwu, nie stanowi fakt, iż inwestycja ta nie spełnia wymogów, o których mowa w art. 4.

4. Decyzje WZ dotyczące budynku mieszkalnego albo budynku o funkcji mieszanej, w skład której wchodzi funkcja mieszkaniowa, wydane przed dniem wejścia w życie ustawy, zachowują moc.

5. Postępowania w przedmiocie wydania decyzji WZ, dotyczące elektrowni wiatrowych, wszczęte i niezakończone do dnia wejścia w życie ustawy umarza się.

6. Decyzje WZ dotyczące elektrowni wiatrowych wydane przed dniem wejścia w życie ustawy tracą moc, chyba że przed dniem wejścia w życie ustawy wobec inwestycji nimi objętych wszczęto postępowanie o wydanie pozwolenia na budowę.

7. Utrata mocy decyzji, o których mowa w ust. 6, nie wymaga stwierdzenia ich wygaśnięcia w trybie określonym w art. 162 Kodeksu postępowania administracyjnego",

- art. $15[\ldots]$

„3. Jeżeli w planie miejscowym, o którym mowa w ust. 2 lub w ust. 7 pkt 1, przewiduje się lokalizację elektrowni wiatrowej, organ administracji architektoniczno-budowlanej odmawia wydania pozwolenia na budowę, a organ prowadzący postępowanie w sprawie decyzji o środowiskowych uwarunkowaniach odmawia zgody na realizację przedsięwzięcia, jeżeli ta inwestycja nie spełnia wymogów, o których mowa w art. 4" [...];

„7. Do projektów planów miejscowych albo ich zmian oraz inwestycji realizowanych na podstawie ustaleń tych planów, w stosunku do których przed dniem wejścia w życie ustawy: [...]

2) nie dokonano wyłożenia, stosuje się przepisy ustawy",

„8. W ciągu 36 miesięcy od dnia wejścia w życie ustawy dopuszcza się uchwalanie planów miejscowych przewidujących lokalizację budynku mieszkalnego albo budynku o funkcji mieszanej, w skład której wchodzi funkcja mieszkaniowa, na podstawie przepisów dotychczasowych.

9. Przepisów ust. 8 nie stosuje się do planów miejscowych przewidujących lokalizację nowej elektrowni wiatrowej",

- art. 17 „Od dnia wejścia w życie ustawy do dnia 31 grudnia 2016 r. podatek od nieruchomości dotyczący elektrowni wiatrowej ustala się i pobiera zgodnie z przepisami obowiązującymi przed dniem wejścia w życie ustawy”.

4. Kwestionowane przepisy prawa budowlanego mają następujące brzmienie:

- art. 3 pkt 3 „Ilekroć w ustawie jest mowa o: [...] budowli - należy przez to rozumieć każdy obiekt budowlany niebędący budynkiem lub obiektem małej architektury, jak: obiekty liniowe, lotniska, mosty, wiadukty, estakady, tunele, przepusty, sieci techniczne, wolno stojące maszty antenowe, wolno stojące trwale 
związane z gruntem tablice reklamowe i urządzenia reklamowe, budowle ziemne, obronne (fortyfikacje), ochronne, hydrotechniczne, zbiorniki, wolno stojące instalacje przemysłowe lub urządzenia techniczne, oczyszczalnie ścieków, składowiska odpadów, stacje uzdatniania wody, konstrukcje oporowe, nadziemne i podziemne przejścia dla pieszych, sieci uzbrojenia terenu, budowle sportowe, cmentarze, pomniki, a także części budowlane urządzeń technicznych (kotłów, pieców przemysłowych, elektrowni jądrowych i innych urządzeń) oraz fundamenty pod maszyny i urządzenia, jako odrębne pod względem technicznym części przedmiotów składających się na całość użytkową”,

- art. 82 ust. 3 pkt 5b „Wojewoda jest organem administracji architektoniczno-budowlanej wyższego stopnia w stosunku do starosty oraz organem pierwszej instancji w sprawach obiektów i robót budowlanych [...] elektrowni wiatrowych, w rozumieniu art. 2 pkt 1 ustawy z dnia 20 maja 2016 r. o inwestycjach w zakresie elektrowni wiatrowych",

- wiersz „Kategoria XXIX” w tabeli stanowiącej załącznik do prawa budowlanego:

\begin{tabular}{|l|c|c|c|c|c|}
\hline \multicolumn{2}{|c|}{} & \multicolumn{3}{|c|}{$\begin{array}{c}\text { Współczynnik wielkości obiektu (w) } \\
\text { (wysokość w m) }\end{array}$} \\
\cline { 3 - 6 } & $\mathbf{3 0}$ & $\mathbf{2 0 - 5 0}$ & $\mathbf{7 5 0 - 1 0 0}$ & $>\mathbf{5 0 0}$ \\
\hline $\begin{array}{l}\text { Kategoria XXIX - wolno stojące } \\
\text { kominy i maszty oraz elektrownie } \\
\text { wiatrowe }\end{array}$ & 10,0 & 1,0 & 1,5 & 2,0 & 2,5 \\
\hline
\end{tabular}

5. Zaskarżone w niniejszym postępowaniu przepisy regulują zasady lokalizacji elektrowni wiatrowych oraz tryb postępowania w tym zakresie. Ponadto kwestionowane przepisy dotyczą trybu postępowania w sprawie budowy elektrowni wiatrowych, w odniesieniu do których przed dniem wejścia w życie ustawy o inwestycjach wydano decyzję o pozwoleniu na budowę bądź też wszczęto przed tą datą postępowanie w sprawie wydania takiej decyzji.

Ustawą o inwestycjach określono, po raz pierwszy w krajowym porządku prawnym, zasady lokalizacji nowych elektrowni wiatrowych. W uzasadnieniu projektu tej ustawy (druk sejmowy nr 315/VIII kad.) wskazano, że obowiązujące dotąd przepisy nie wyznaczały w dostatecznym stopniu ram prawnych dla lokalizowania, budowy i eksploatacji elektrowni wiatrowych. W konsekwencji instalacje tego rodzaju były lokalizowane zbyt blisko budynków mieszkalnych. Sytuacja ta była uciążliwa dla osób zamieszkałych w bezpośrednim sąsiedztwie elektrowni wiatrowych, jako że funkcjonowanie tych instalacji wiąże się z emisją hałasu, infradźwięków, wibracji, powstawaniem efektu migotania światła itp. Elektrownie te mogą także stanowić źródło bezpośredniego zagrożenia życia lub zdrowia okolicznych mieszkańców w przypadku awarii, jak również oblodzenia łopat elektrowni wiatrowej zimą. Taki stan miał charakter konfliktogenny, prowadząc do sporów między mieszkańcami a władzami gmin, które wydawały zgodę na budowę elektrowni w niewielkiej odległości od zabudowań mieszkalnych (uzasadnienie projektu, s. 1). Celem prawodawcy było zatem uregulowanie 
na szczeblu ustawowym warunków lokalizacji elektrowni wiatrowych. Ponadto unormowane w niej niektóre kwestie związane ze statusem prawnym tego typu obiektów, dotyczącym ich kwalifikacji na gruncie prawa budowlanego.

Dla uniknięcia wątpliwości interpretacyjnych w ustawie o inwestycjach zdefiniowano pojęcie elektrowni wiatrowej. W świetle art. 2 pkt 1 tej ustawy elektrownią wiatrową jest instalacja odnawialnego źródła energii, składająca się z części budowlanej stanowiącej budowlę w rozumieniu prawa budowlanego oraz urządzeń technicznych, w tym elementów technicznych, w której energia elektryczna jest wytwarzana $z$ energii wiatru, o mocy większej niż moc mikroinstalacji w rozumieniu art. 2 pkt 19 ustawy z dnia 20 lutego 2015 r. o odnawialnych źródłach energii (t.j. Dz. U. 2018, poz. 2389, ze zm.). Ustawodawca doprecyzował także, jakie elementy techniczne składają się na elektrownię wiatrową - zaliczają się do nich wirnik z zespołem łopat, zespół przeniesienia napędu, generator prądotwórczy, układy sterowania i zespół gondoli wraz z mocowaniem i mechanizmem obrotu (zob. art. 2 pkt 2 ustawy). Należy zauważyć, że brak tej definicji w dotychczasowym stanie prawnym powodował, że elektrownie wiatrowe - przy wydawaniu decyzji o warunkach zabudowy i pozwoleniu na budowę - były klasyfikowane w niejednolity sposób, w tym w szczególności jako maszty, wieże, urządzenia energetyczne itp. Uwzględniając zakres zaskarżenia przyjęty w obu wnioskach, podstawowe rozwiązania przyjęte w ustawie można ująć w postaci następujących zasad:

- warunkiem wydania pozwolenia na budowę elektrowni wiatrowej jest dopuszczenie lokalizacji tego typu obiektu (ich zespołu) w miejscowym planie zagospodarowania przestrzennego. Zasada ta została wyrażona w art. 3 ustawy. Warto zauważyć, że przed wejściem w życie ustawy miejscowe plany mogły przewidywać lokalizację elektrowni wiatrowych. Natomiast jeżeli dla danego obszaru nie obowiązywał miejscowy plan, wówczas zgoda na lokalizację elektrowni wiatrowej - jako obiektu budowlanego - następowała na podstawie decyzji o warunkach zabudowy, wydawanej w trybie określonym w art. 59 i n. ustawy z dnia 27 marca 2003 r. o planowaniu i zagospodarowaniu przestrzennym (t.j. Dz. U. 2018, poz. 1945, ze zm.; dalej: ustawa o planowaniu). Przed wejściem w życie ustawy budowa elektrowni wiatrowej mogła zatem nastąpić na obszarze, dla którego nie obowiązywał miejscowy plan zagospodarowania przestrzennego,

- warunkiem wydania pozwolenia na budowę elektrowni wiatrowej jest, niezależnie od warunku określonego wyżej w pkt 1, zachowanie minimalnej odległości takiej instalacji od zabudowań mieszkalnych lub form ochrony przyrody, o których mowa w art. 6 ust. 1 pkt $1-3$ i pkt 5 ustawy z dnia 16 kwietnia 2004 r. o ochronie przyrody (t.j. Dz. U. 2018, poz. 1614, ze zm.) oraz od leśnych kompleksów promocyjnych, o których mowa w art. $13 \mathrm{~b}$ ust. 1 ustawy z dnia 28 września 1991 r. o lasach (t.j. Dz. U. 2018, poz. 2129, ze zm.). Zgodnie z art. 4 ust. 1 ustawy o inwestycjach minimalna odległość elektrowni wiatrowej od zabudowy mieszkaniowej oraz wskazanych form ochrony/pro- 
mocji przyrody powinna wynosić nie mniej niż dziesięciokrotność wysokości całkowitej elektrowni wiatrowej, liczonej od poziomu gruntu do najwyższego punktu budowli, uwzględniając wirnik wraz z łopatami. Przyjęty limit wysokości jest określany w piśmiennictwie w skrócie jako „kryterium 10H” (skrót ten jest stosowany także w dalszej części stanowiska). Szczegółowy sposób obliczania odległości między elektrownią a wymienionymi obiektami określa art. 5 ustawy. Limity wprowadzone ustawą mają zastosowanie również do lokalizacji budynków mieszkalnych w sąsiedztwie elektrowni wiatrowych minimalna odległość nowo powstającej zabudowy musi spełniać kryterium 10H. Limit odległości wyznaczony w art. 4 ust. 1 ustawy jest wiążący dla gminy przy: a) sporządzaniu oraz uchwalaniu studium uwarunkowań i kierunków zagospodarowania przestrzennego gminy albo jego zmianie; b) sporządzaniu oraz uchwalaniu albo przyjmowaniu planu miejscowego albo jego zmianie; c) wydawaniu decyzji w sprawie ustalenia warunków zabudowy. Jest on wiążący także przy wydawaniu decyzji o środowiskowych uwarunkowaniach inwestycji (art. 6 ustawy),

- po wejściu w życie ustawy dopuszcza się dalsze funkcjonowanie elektrowni wiatrowych funkcjonujących przed tą datą, także gdy nie zostały one przewidziane $\mathrm{w}$ miejscowym planie zagospodarowania przestrzennego lub nie spełniają kryterium $10 \mathrm{H}$. W tym ostatnim przypadku został jednak wprowadzony zakaz ich rozbudowy. Zezwala się bowiem na przeprowadzenie ich remontu oraz wykonywanie innych czynności niezbędnych do prawidłowego użytkowania elektrowni, z wyłączeniem działań prowadzących do zwiększenia parametrów użytkowych elektrowni lub zwiększenia jej oddziaływania na środowisko (art. 12 ustawy),

- dopuszczono - po dniu wejścia w życie ustawy - możliwość budowy elektrowni wiatrowych, których lokalizacja nie spełnia kryterium $10 \mathrm{H}$, o ile przed dniem wejścia w życie ustawy zostało wydane pozwolenie na budowę elektrowni. W takim wypadku inwestycja musi zostać zrealizowana przed upływem 3 lat od wejścia w życie ustawy. Jeżeli przed upływem wskazanego okresu nie zostanie wydane pozwolenie na użytkowanie, wówczas wybudowana już elektrownia podlega rozbiórce na koszt inwestora,

- wraz z wejściem w życie ustawy o inwestycjach nastąpiła utrata mocy prawnej decyzji o warunkach zabudowy dotyczących planowanych inwestycji w zakresie elektrowni wiatrowych, chyba że przed tą datą zostało wszczęte postępowanie o wydanie pozwolenia na budowę (art. 14 ust. 6 ustawy). Analogicznie umorzeniu podlegają postępowania w przedmiocie wydania decyzji o warunkach zabudowy i zagospodarowania terenu (dalej: decyzja o warunkach zabudowy), dotyczące elektrowni wiatrowych, wszczęte i niezakończone do dnia wejścia w życie ustawy (art. 14 ust. 5 ustawy),

- elektrownie wiatrowe - jako całość - zostały zaliczone do kategorii budowli w rozumieniu art. 3 pkt 3 prawa budowlanego. Przed wejściem w życie usta- 
wy o inwestycjach do kategorii budowli zaliczano wyłącznie części budowlane elektrowni wiatrowych. Natomiast w stanie prawnym właściwym na dzień wystąpienia $\mathrm{z}$ wnioskami inicjującymi niniejsze postępowanie w pojęciu budowli zawierają się zarówno części budowlane elektrowni (wieża), jak i jej części techniczne (przekładnia, rotor, zespół sterujący itd.). Na gruncie prawa budowlanego oznacza to poddanie całości elektrowni wiatrowej, a więc zarówno jej elementów stricte budowlanych, jak i elementów o charakterze technicznym, nadzorowi budowlanemu. Wprowadzona zmiana ma także aspekt prawnopodatkowy, skutkując zmianą przedmiotu opodatkowania podatkiem od nieruchomości. Opodatkowaniu podlegają bowiem nie tylko części budowlane, ale także części techniczne elektrowni. Skutkuje to kilkukrotnym (wedle szacunków o ok. 400-500\%) zwiększeniem obciążenia podatkiem od nieruchomości za elektrownie wiatrowe,

- wprowadzono obowiązek uzyskania decyzji o pozwoleniu na użytkowanie elektrowni wiatrowej (art. 8 ustawy o inwestycjach).

\section{Analiza formalnoprawna}

1. Zgodnie z petitum wniosku II, przedmiot kontroli stanowią nie tylko enumeratywnie wymienione przepisy ustawy o inwestycjach, ale ponadto ustawa w całości. Uzasadniając zaskarżenie całej ustawy, Wnioskodawca II ograniczył się do stwierdzenia, że: „jak wynika z wyżej przedstawionych analiz, podstawowy zakres normatywny Ustawy objęty zarzutami postawionymi w pkt. 1-4 petitum niniejszego wniosku jest rażąco sprzeczny z Konstytucją, konieczne jest stwierdzenie niezgodności z Konstytucją całej Ustawy, ponieważ stwierdzenie niezgodności przepisów Ustawy wskazanych w pkt. 1-4 petitum wniosku powoduje utratę spójności normatywnej całej Ustawy. Wyeliminowanie Ustawy w całości z obrotu prawnego staje się w tych okolicznościach konieczne" (wniosek II, s. 35).

Odnosząc się do wniosku o poddanie kontroli konstytucyjności całej ustawy, należy zwrócić uwagę na następujące okoliczności. Przede wszystkim, zasadność poddania kontroli przez Trybunał Konstytucyjny całej ustawy występuje w pierwszej kolejności w przypadku, gdy sformułowane we wniosku zarzuty mają charakter proceduralny (a więc wnioskodawca kwestionuje prawidłowość przebiegu procedury, w której doszło do ustanowienia zaskarżonego aktu) bądź też kompetencyjny (kwestionowany akt został wydany przez organ/podmiot, któremu w tym wypadku nie przysługiwała kompetencja prawodawcza). W obu wskazanych sytuacjach wadliwością dotknięte są bowiem - zazwyczaj - w równym stopniu wszystkie przepisy kwestionowanego aktu, niezależnie od ich treści. Wystąpienie wadliwości przepisów o charakterze proceduralnym stanowi najczęściej występującą sytuację, w której Trybunał Konstytucyjny oceniał zgodność z Konstytucją całego aktu.

Incydentalnie kontrola całości aktu normatywnego przez Trybunał była przeprowadzana wówczas, gdy podniesione zarzuty odnosiły się do merytorycznej treści kwestionowanego aktu. Mogło to dotyczyć sytuacji, gdy wnioskodawca 
zakwestionował konstytucyjność wszystkich przepisów składających się na akt poddany kontroli bądź też takich, które miały podstawowe znaczenie dla materii regulowanej w zaskarżonym akcie. W tym ostatnim przypadku zakwestionowanie całego aktu miało przeciwdziałać sytuacji, w której w następstwie orzeczenia Trybunału o niekonstytucyjności poszczególnych przepisów w obrocie prawnym nadal pozostawałby akt, który de facto przestał obowiązywać.

W uzasadnieniu wniosku II nie wykazano, aby wystąpiła którakolwiek z wymienionych wyżej sytuacji. W szczególności brak jest podstaw do przyjęcia, że kwestionowane przepisy odznaczają się tego rodzaju powiązaniem z ustawą o inwestycjach, że niecelowe jest dalsze pozostawienie w obrocie prawnym tej ustawy. Wnioskodawca II wskazał wprawdzie, że w wyniku wyroku Trybunału stwierdzającego niekonstytucyjność przepisów poddanych kontroli dojdzie do „utraty spójności normatywnej całej ustawy”, ale wystąpienia tej okoliczności nie udowodnił. Daleko posunięta lakoniczność uzasadnienia w sprawie poddania kontroli całej ustawy również przemawia przeciwko uwzględnieniu powyższego wniosku. Wreszcie, Wnioskodawca II nie wskazał, że przepisy ustawy nieobjęte petitum wniosku II (a więc przepisy składające się na całość ustawy, co do których we wniosku II nie zostały sformułowane zarzuty) nie mają samodzielnej treści normatywnej, co stanowiłoby przesłankę na rzecz stwierdzenia niekonstytucyjności całej ustawy. W związku z powyższym należy wyrazić stanowisko, że wniosek dotyczący poddania ocenie konstytucyjności całej ustawy nie znajduje podstaw, a postępowanie w tym zakresie podlega - na podstawie art. 59 ust. 1 pkt 2 ustawy z dnia 30 listopada 2016 r. o organizacji i trybie postępowania przed Trybunałem Konstytucyjnym (Dz. U. poz. 2072, ze zm.; dalej: ustawa o TK) umorzeniu ze względu na niedopuszczalność wydania wyroku.

2. W dalszej kolejności należy doprecyzować przedmiot kontroli w niniejszym postępowaniu. Zgodnie z petitum wniosku I, jak i petitum wniosku II przedmiot kontroli został wyznaczony bardzo szeroko, obejmując liczne przepisy ustawy o inwestycjach. Tymczasem, w stosunku do znacznej części zakwestionowanych przepisów, w uzasadnieniach obydwu wniosków nie zostały powołane żadne zarzuty. Dotyczy to w szczególności:

- art. 4 ust. 2 i ust. 3 ustawy o inwestycjach. Przepisy te przewidują zachowanie kryterium $10 \mathrm{H}$ w odniesieniu do form ochrony przyrody, o których mowa w art. 6 ust. 1 pkt $1-3$ i pkt 5 ustawy z dnia 16 kwietnia 2004 r. o ochronie przyrody oraz w odniesieniu do leśnych kompleksów promocyjnych, o których mowa w art. 13b ust. 1 ustawy z dnia 28 września 1991 r. o lasach. Zarzuty sformułowane $\mathrm{w}$ obu wnioskach odnoszą się natomiast wyłącznie do wynikającego $\mathrm{z}$ art. 4 ust. 1 ustawy o inwestycjach obowiązku zachowania minimalnej odległości pomiędzy elektrownią wiatrową a zabudową mieszkaniową. Wnioskodawcy nie odnieśli się zaś w żaden sposób do kwestii odległości między tymi elektrowniami a formami ochrony przyrody oraz leśnymi kompleksami promocyjnymi, 
- art. 5 ust. 1 ustawy o inwestycjach, który precyzuje sposób ustalenia minimalnej odległości wynikającej z zastosowania kryterium $10 \mathrm{H}$ między elektrownią wiatrową a zabudową o funkcji mieszkaniowej. Żaden z wnioskodawców nie podniósł zarzutów w stosunku do przyjętych w tym przepisie zasad ustalenia minimalnej odległości, koniecznej dla spełnienia kryterium $10 \mathrm{H}$,

- art. 5 ust. 2 ustawy, który pod pojęciem obiektu budowlanego nakazuje rozumieć również obiekty budowlane objęte decyzją o pozwoleniu na budowę albo zgłoszeniem, wobec którego organ administracji architektoniczno-budowlanej nie wniósł sprzeciwu. Wnioskodawcy nie zakwestionowali regulacji zawartej w tym przepisie,

- art. 5 ust. 3 ustawy, który precyzuje sposób ustalania odległości między elektrownią wiatrową a formami ochrony przyrody bądź leśnym kompleksem promocyjnym. Także w tym wypadku w obu wnioskach brak jest jakiegokolwiek uzasadnienia odnoszącego się do kwestii niezgodności z Konstytucją powyższego przepisu,

- art. 14 ust. 1-4 i ust. 7 ustawy. Artykuł 14 ma charakter przepisu międzyczasowego regulującego skutki prawne wejścia w życie ustawy o inwestycjach do wydanych przed tą datą decyzji o warunkach zabudowy, dotyczących budynku mieszkalnego albo elektrowni wiatrowych, jak również wszczętych i niezakończonych postępowań dotyczących wydania takich decyzji. Zarzuty podniesione przez obydwu wnioskodawców dotyczą wyłącznie spraw uregulowanych w art. 14 ust. 5 (umorzenie niezakończonych przed dniem wejścia w życie ustawy postępowań w sprawie wydania warunków zabudowy dotyczących elektrowni wiatrowych) oraz w art. 14 ust. 6 ustawy (utrata mocy decyzji w sprawie warunków zabudowy dotyczących elektrowni wiatrowych). Uzasadnienie przytoczone we wniosku I oraz wniosku II nie odnosi się natomiast do zagadnień uregulowanych w art. 14 ust. 1-4 i ust. 7 ustawy,

- art. 15 ust. 7 pkt 2 ustawy o inwestycjach, nakazujący stosować przepisy tej ustawy do projektów planów miejscowych albo ich zmian oraz inwestycji realizowanych na podstawie ustaleń tych planów, w stosunku do których przed dniem wejścia w życie ustawy nie dokonano wyłożenia. W argumentacji zawartej w uzasadnieniu Wnioskodawca I nie odniósł się w żaden sposób do spraw normowanych w tym przepisie,

- wiersz „Kategoria XXIX” w tabeli stanowiącej załącznik do prawa budowlanego, określający współczynnik wielkości obiektu w odniesieniu do wolno stojących kominów i masztów oraz elektrowni wiatrowych. Wnioskodawca II nie przedstawił argumentacji dotyczącej niekonstytucyjności wiersza „Kategoria XXIX”.

Należy zwrócić uwagę, że przedmiot kontroli przed Trybunałem Konstytucyjnym stanowić mogą jedynie te jednostki redakcyjne aktu prawnego, które - w jakikolwiek sposób - zostały powiązane z zarzutami sformułowanymi 
w uzasadnieniu pisma inicjującego postępowanie przed sądem konstytucyjnym. W wymiarze normatywnym powyższą zasadę wyrażają art. 47 ust. 1 pkt 6 i ust. 2 pkt 3-4 ustawy o TK, z których wynika obowiązek uzasadnienia wniosku inicjującego postępowanie przed Trybunałem Konstytucyjnym. Na uzasadnienie składa się w szczególności określenie problemu konstytucyjnego i zarzutu niekonstytucyjności, jak również wskazanie argumentów lub dowodów na poparcie zarzutu niekonstytucyjności. W przypadku niespełnienia przez wniosek powyższych wymogów zainicjowane nim postępowanie podlega - w odpowiednim zakresie - umorzeniu jako niedopuszczalne na podstawie art. 59 ust. 1 pkt 2 ustawy o TK.

Obowiązek właściwego uzasadnienia zarzutu we wskazanym zakresie ma utrwalone znacznie w dotychczasowym orzecznictwie Trybunału Konstytucyjnego. Zgodnie ze stanowiskiem sądu konstytucyjnego „nie wystarcza sformułowanie samej tezy o niekonstytucyjności przepisu wraz z przytoczeniem literalnego brzmienia wzorca kontroli. Wnioskodawca powinien wskazać precyzyjnie co najmniej jeden argument za naruszeniem określonych wzorców kontroli, który ma znaczenie konstytucyjne, to znaczy może być uwzględniony w toku kontroli konstytucyjności prawa" (wyroki TK z: 31 lipca 2015 r., sygn. akt K 41/12 i 3 grudnia 2015 r., sygn. akt K 34/15), jak również „Wskazanie w petitum wzorca kontroli, przy respektowaniu generalnej zasady, jaką jest domniemanie konstytucyjności aktu normatywnego, bez szczegółowego odniesienia się do niego w uzasadnieniu lub lakoniczne sformułowanie zarzutu niekonstytucyjności nie może bowiem zostać uznane za «uzasadnienie postawionego zarzutu z powołaniem dowodów na jego poparcie» w rozumieniu przepisów regulujących postępowanie przed Trybunałem Konstytucyjnym" (m.in. wyrok TK z 14 grudnia 2017 r., sygn. akt K 17/14, oraz postanowienia TK z: 1 marca 2017 r., sygn. akt K 13/14; 7 lutego 2018 r., sygn. akt SK 20/15; 30 października 2018 r., sygn. akt P 15/16). Wskazuje się ponadto, że: „[w] świetle utrwalonej praktyki orzeczniczej wymóg ten należy rozumieć jako nakaz odpowiedniego udowodnienia zarzutów stawianych w kontekście każdego wskazanego wzorca kontroli" (wyrok TK z 28 listopada 2013 r., sygn. akt K 17/12 oraz postanowienie TK z 30 października 2018 r., sygn. akt P 15/16). Trybunał wyjaśnił także, że: „[n]ie realizują omawianych wymagań uwagi nazbyt ogólne, niejasne czy też czynione jedynie na marginesie innych rozważań" (wyroki TK z 5 czerwca 2014 r., sygn. akt K 35/11 i 17 lipca 2018 r., sygn. akt K 9/17) oraz „[u]zasadnienie zarzutów nie może być traktowane powierzchownie i instrumentalnie, nie może mieć charakteru pozornego. Argumentacja konstytucyjna bywa mniej lub bardziej przekonująca, może też ostatecznie okazać się nietrafna lub niekompletna, ale zawsze musi być weryfikowalna i możliwa do rozpoznania przez Trybunał" (wyrok TK z 3 grudnia 2015 r., sygn. akt K 34/15). Dopuszczenie kontroli pomimo nieprzedstawienia przez wnioskodawcę właściwego uzasadnienia oznaczałoby, że to Trybunał Konstytucyjny zobowiązany jest samodzielnie powołać argumenty dotyczące zgodności 
(niezgodności) kwestionowanych przepisów z przywołanymi przez wnioskodawcę wzorcami, co jest sprzeczne z zasadami wyznaczającymi ciężar dowodu w postępowaniu przez sądem konstytucyjnym (m.in. wyrok TK z 15 kwietnia 2014 r., sygn. akt SK 48/13).

Mając na względzie powyższe, Sejm wnosi o umorzenie postępowania w zakresie kontroli konstytucyjności art. 4 ust. 2-3, art. 5, art. 14 ust. 1-4 i ust. 7 oraz art. 15 ust. 7 pkt 2 ustawy o inwestycjach, a także wiersza „Kategoria XXIX” w tabeli stanowiącej załącznik do ustawy - Prawo budowlane, ze względu na brak przedstawienia przez wnioskodawców uzasadnienia spełniającego wymogi określone w ustawie o TK.

3. Niedopełnienie przez podmioty inicjujące niniejsze postępowanie obowiązków związanych z właściwym uzasadnieniem wniosku polega ponadto, poza okolicznościami wskazanymi w pkt 2, na braku powiązania sformułowanych zarzutów z niektórymi wzorcami kontroli wymienionymi w petitach wniosków.

W przypadku Wnioskodawcy I brak uzasadnienia w powyższym zakresie dotyczy art. 20, art. 21 ust. 1, zasady pomocniczości wywodzonej z preambuły, zasady proporcjonalności wywodzonej z art. 2 Konstytucji, art. 15 ust. 1 i art. 166 ust. 1 Konstytucji. I tak, przedstawiając wyjaśnienia dotyczące niezgodności art. 4-6 ustawy z art. 20 Konstytucji (pkt 1 petitum wniosku I) ograniczono się do stwierdzenia, że: „ustawodawca przekroczył w tym zakresie ramy dopuszczalnej ingerencji ustawodawcy w społeczną gospodarkę rynkową" (wniosek I, s. 21). Uzasadnienie tej treści nie może być uznane za spełniające obowiązek wynikający z ustawy o TK.

Natomiast w odniesieniu do art. 21 ust. 1 Konstytucji (zasada ochrony prawa własności) Wnioskodawca I każdorazowo powołuje ten przepis jako dopełnienie wzorca zawartego w art. 64 Konstytucji. Ten ostatni statuuje prawo własności jako jedno z praw konstytucyjnych przysługujących jednostce. Przy tym argumentacja powołana w uzasadnieniu wniosku I koncentruje się wyłącznie na naruszeniu prawa własności i innych praw majątkowych przysługujących podmiotom podejmującym inwestycje w zakresie energetyki wiatrowej, a więc bezsprzecznie dotyczy art. 64 Konstytucji. Wnioskodawca I nie wykazał w żaden sposób, w czym przejawia się niezgodność kwestionowanych przezeń przepisów ustawy o inwestycjach z art. 21 ust. 1 Konstytucji, jako zasadą ustrojową przewidującą poddanie ochronie Rzeczypospolitej własności i prawa dziedziczenia. W tym stanie przywołanie art. 21 ust. 1 Konstytucji ma wyłącznie charakter ornamentacyjny, nie towarzyszy mu natomiast jakiekolwiek uzasadnienie.

W dalszej kolejności należy wskazać, że w pkt 2 petitum wniosku I sformułowany został wniosek o stwierdzenie niezgodności wymienionych tam przepisów ustawy o inwestycjach z zasadą pomocniczości wywodzoną z preambuły, z zasadą proporcjonalności wywodzoną $\mathrm{z}$ art. 2, a ponadto $\mathrm{z}$ art. 15 ust. 1, art. 16 ust. 2, art. 165 i art. 166 ust. 1 Konstytucji. Przedstawione przez Wnioskodawcę I uzasadnienie obejmuje jednak wyłącznie zarzut naruszenia zasady samodzielności 
samorządu terytorialnego. Spośród powołanych wzorców zasada samodzielności może być wywodzona $\mathrm{z}$ art. 16 ust. 2 oraz art. 165 ust. 1 i 2. Brak jest zatem podstaw, aby jako wzorce kontroli dotyczące naruszenia zasady samodzielności samorządu przywoływać także zasadę pomocniczości wywodzoną z preambuły, zasadę proporcjonalności wywodzoną $\mathrm{z}$ art. 2 Konstytucji, art. 15 ust. 1 (zasada decentralizacji) oraz art. 166 ust. 1 Konstytucji (zadania własne samorządu), w szczególności że Wnioskodawca I nie wykazał występowania takiego powiązania. $\mathrm{W}$ stosunku do wymienionych wzorców nie została również przedstawiona samodzielna argumentacja dotycząca ich naruszenia.

Z kolei brak powiązania zarzutów z powołanymi wzorcami występuje - na płaszczyźnie wniosku II - w odniesieniu do art. 164 i art. 166, a także art. 2 i art. 20 (w zakresie wymienionym w pkt 1 petitum wniosku II), art. 32 ust. 2 oraz art. 74 ust. 4 Konstytucji. W przypadku zarzutu dotyczącego naruszenia art. 164 i art. 166 Konstytucji trzeba wskazać, że przepisy te zostały wskazane jako wzorce kontroli w zakresie, w jakim stanowią źródło konstytucyjnej zasady pomocniczości (zob. wniosek II, s. 22). Takie potraktowanie wymienionych wzorców musi budzić wątpliwości. Przede wszystkim nie może być uznane za trafne stanowisko, $\mathrm{w}$ świetle którego wymienione przepisy stanowią podstawę do wywiedzenia konstytucyjnej zasady pomocniczości. Wprawdzie niektóre z tych postanowień mogą być uznane - w pewnym stopniu - za emanację powyższej zasady (art. 164 ust. 1 Konstytucji: „Podstawową jednostką samorządu terytorialnego jest gmina”; art. 164 ust. 3 Konstytucji: „Gmina wykonuje wszystkie zadania samorządu terytorialnego nie zastrzeżone dla innych jednostek samorządu terytorialnego”; art. 166 ust. 1 Konstytucji: „Zadania publiczne służące zaspokajaniu potrzeb wspólnoty samorządowej są wykonywane przez jednostkę samorządu terytorialnego jako zadania własne”). Nie oznacza to jednak, że przepisy te stanowią samodzielnie podstawę do wywodzenia z nich zasady pomocniczości, zaś Wnioskodawca II nie przytoczył w tym względzie stosownej argumentacji. Zasada pomocniczości została wyrażona wyłącznie w preambule Konstytucji („ustanawiamy Konstytucję Rzeczypospolitej Polskiej jako prawa podstawowe dla państwa oparte na zasadzie pomocniczości umacniającej uprawnienia obywateli i ich wspólnot"), stąd też zarzut sformułowany przez Wnioskodawcę II powinien podlegać ocenie wyłącznie z punktu widzenia tak ujętego wzorca. Także w orzecznictwie sądu konstytucyjnego nie znajduje potwierdzenia stanowisko, aby art. 164 oraz art. 166 Konstytucji miały stanowić podstawę do wyprowadzenia $\mathrm{z}$ nich zasady pomocniczości.

Podkreślić przy tym trzeba, że Wnioskodawca II nie sformułował w odniesieniu do art. $164 \mathrm{i}$ art. 166 Konstytucji żadnych innych zarzutów ponad te związane z zasadą pomocniczości. Pominięto również, że powołane wzorce konstytucyjne zawierają regulacje dotyczące wielu aspektów związanych ze strukturą samorządu (art. 164 Konstytucji) i zadaniami realizowanymi przez samorząd (art. 166 Konstytucji). Znalazło to wyraz w złożonej strukturze wymienionych wzorców; 
każdy z nich składa się z trzech odrębnych ustępów. Wnioskodawca II nie wskazał w żaden sposób, który z tych ustępów, a także w jaki sposób został naruszony przez kwestionowane przepisy ustawy o inwestycjach.

W dalszej kolejności odnieść się trzeba do kwestii braku uzasadnienia przez Wnioskodawcę II zarzutów obejmujących art. 2 i art. 20 (w zakresie niezgodności z przepisami ustawy o inwestycjach wymienionymi w pkt 1 petitum wniosku), art. 32 ust. 2 oraz art. 74 ust. 4 Konstytucji. Argumentacja powołana przez Wnioskodawcę II w najmniejszym stopniu nie wyjaśnia, w czym przejawia się naruszenie tych przepisów. Ilustrację powyższego stanowi choćby fragment uzasadnienia dotyczący naruszenia art. 32 ust. 2 Konstytucji, w którym Wnioskodawca II ograniczył się do następującego stwierdzenia: „Pozbawienie inwestorów możliwości lokowania inwestycji na podstawie decyzji o warunkach zabudowy stanowi naruszenie wolności działalności gospodarczej w sposób niezgodny $\mathrm{z}$ art. 22 Konstytucji, czyli w sytuacji braku ważnego interesu publicznego uzasadniającego takie ograniczenie. W świetle art. 32 ust. 2 Konstytucji stanowi to dyskryminacyjne potraktowanie energetyki wiatrowej" (wniosek II, s. 6). Z kolei w odniesieniu do zarzutu obejmującego naruszenie art. 74 ust. 4 Konstytucji stwierdzono jedynie, że: „Rozwój energetyki wiatrowej realizuje normę art. 74 ust. 1-4 Konstytucji, ponieważ energetyka wiatrowa jako odnawialne źródło energii służy ochronie środowiska naturalnego" (wniosek II, s. 31). Powyższe wyjaśnienia nie mogą w żaden sposób zostać uznane za realizację wynikającego z ustawy o TK obowiązku uzasadnienia podniesionego zarzutu, wraz z powołaniem dowodów na jego poparcie. Analogicznie, brak uzasadnienia odnosi się do zarzutu dotyczącego naruszenia art. 2 i art. 20 (w zakresie niezgodności z przepisami ustawy o inwestycjach wymienionymi w pkt 1 petitum wniosku).

Mając na uwadze powyższe, należy przyjąć, że postępowanie w zakresie obejmującym wymienione wzorce, tj. zasadę pomocniczości i zasadę proporcjonalności wywodzone z art. 2 Konstytucji (dotyczy przepisów ustawy o inwestycjach wymienionych w pkt 2 petitum wniosku I), art. 15 ust. 1, art. 20 Konstytucji (dotyczy przepisów ustawy o inwestycjach wymienionych w pkt 1 petitum wniosku I), art. 21 ust. 1, art. 32 ust. 2, art. 74, art. 164 i art. 166 Konstytucji podlega umorzeniu ze względu na niedopuszczalność wydania wyroku.

4. Zgodnie $\mathrm{z}$ art. 47 ust. 2 pkt 2 ustawy o TK uzasadnienie wniosku zawiera m.in. przywołanie treści wzorców kontroli wraz z ich wykładnią. W odniesieniu do części wzorców kontroli wskazanych w petitum wniosku II powyższy wymóg nie został zrealizowany.

Należy zauważyć, że wniosek II został złożony 19 grudnia 2016 r., a więc jeszcze przed wejściem w życie obecnej ustawy o TK. W takim wypadku, zgodnie z ustawą z dnia 13 grudnia 2016 r. - Przepisy wprowadzające ustawę o organizacji i trybie postępowania przed Trybunałem Konstytucyjnym oraz ustawę o statusie sędziów Trybunału Konstytucyjnego (Dz. U. poz. 2074, ze zm.), zastosowanie znajduje zasada bezpośredniego działania nowego prawa (art. 9 ust. 1 tej ustawy: 
„Do postępowań przed Trybunałem Konstytucyjnym, zwanym dalej «Trybunałem», wszczętych i niezakończonych przed dniem wejścia w życie ustawy, o której mowa w art. 1, stosuje się przepisy tej ustawy"). Oznacza to, że do wniosku wniesionego 19 grudnia 2016 r. znajduje w pełnym zakresie zastosowanie art. 47 ust. 2 pkt 2 ustawy o TK. W razie braku wykonywania obowiązku określonego w art. 47 ust. 2 pkt 2 ustawy o TK postępowanie w zakresie rozpatrzenia danego zarzutu powinno podlegać umorzeniu ze względu na niedopuszczalność wydania orzeczenia. Ewentualnie braki w tym zakresie mogą jednak zostać uzupełnione przez wnioskodawcę do czasu otwarcia rozprawy, czego wnioskodawca dotychczas nie dopełnił.

\section{Dopuszczenie lokalizacji elektrowni wiatrowej wyłącznie na podstawie miejscowego planu zagospodarowania przestrzennego}

\section{- 1. Zarzuty wnioskodawcy}

Zarzut obejmujący art. 3 ustawy, zgodnie z którym lokalizacja i budowa elektrowni wiatrowej może nastąpić wyłącznie na podstawie miejscowego planu zagospodarowania przestrzennego, został sformułowany przez Wnioskodawcę II.

Kwestionowana regulacja wyłącza możliwość zastosowania dotychczasowego trybu lokowania elektrowni wiatrowych, tj. ustalenia lokalizacji elektrowni na podstawie decyzji o warunkach zabudowy. W konsekwencji, w ocenie Wnioskodawcy II, budowa elektrowni wiatrowych wymaga - w obecnym stanie prawnym - bardziej skomplikowanej procedury, co szczególnie uderza w małe inwestycje składające się z 2-3 wiatraków. Ponadto planami miejscowymi objęty jest jedynie niewielki obszar powierzchni Polski. Odnosi się to w szczególności do gmin wiejskich, na obszarze których w większości przypadków sytuowane są elektrownie wiatrowe. $\mathrm{Na}$ tym tle wprowadzenie wymogu uwzględnienia lokalizacji elektrowni wiatrowej w miejscowym planie stanowi, zdaniem Wnioskodawcy II, regulację wyjątkową. Obowiązek taki nie dotyczy bowiem innych sfer działalności usługowej lub przemysłowej, dla których wystarczające jest legitymowanie się decyzją o warunkach zabudowy.

Uzasadniając zarzut niezgodności art. 3 ustawy o inwestycjach z art. 22 Konstytucji, Wnioskodawca II wskazał na brak występowania ważnego interesu publicznego, który uzasadniałby wprowadzenie ograniczeń w sferze działalności gospodarczej obejmującej budowę i eksploatację elektrowni wiatrowych. Wyjaśniając pojęcie interesu publicznego, wskazał, że chodzi o sytuację polegającą na kreowaniu „wartości oraz stanów, które będą się przyczyniały do dobra możliwie dużej liczby ludzi (zainteresowanych danym rozstrzygnięciem lub daną sytuacją) i które zaspokoją interesy i potrzeby jak najszerszego kręgu obywateli, powodując równocześnie zło czy też negację interesu indywidualnego u jak najmniejszego grona osób” (wniosek II, s. 8). Tymczasem ograniczenia wynikające z kwestionowanych przepisów ustawy nie zapewniają ochrony „słusznego intere- 
su zdecydowanej grupy społecznej”. Nie jest nim w szczególności „partykularny interes nielicznych grup społecznych, które są zainteresowane jedynie zniweczeniem konkurencyjności elektrowni wiatrowych" (wniosek II, s. 9).

Wprowadzenie przez ustawodawcę ograniczeń wyłącznie w odniesieniu do działalności gospodarczej w sferze elektrowni wiatrowych ma zarazem charakter dyskryminujący i przesądza o niezgodności art. 3 ustawy o inwestycjach z art. 32 ust. 1 Konstytucji. Wejście w życie ustawy skutkuje utrudnieniem bądź nawet uniemożliwieniem przyłączania elektrowni wiatrowych do sieci energetycznej. Wynika to stąd, że na podstawie art. 8a ustawy z dnia 10 kwietnia 1997 r. - Prawo energetyczne, występując w wnioskiem o przyłączenie do sieci energetycznej źródeł innych niż mikroinstalacje, należy dołączyć wypis i wyrys z miejscowego planu zagospodarowania przestrzennego, a w przypadku braku takiego planu, decyzję o warunkach zabudowy i zagospodarowania terenu. Ten ostatni warunek nie może być spełniony przez podmiot występujący o lokalizację elektrowni wiatrowej, co przesądza o nierównym traktowaniu w stosunku do innych podmiotów.

Zdaniem Wnioskodawcy II ograniczenia w sferze wolności działalności gospodarczej pozostają także w sprzeczności z zasadą proporcjonalności (art. 31 ust. 3 Konstytucji). Wprawdzie kwestionowana regulacja służy celowi przypisywanemu ustawie przez Wnioskodawcę II, a więc wyłącza możliwość budowy nowych elektrowni wiatrowych. Realizuje pośrednio także cel założony przez ustawodawcę, a więc ogranicza niekorzystne oddziaływanie elektrowni wiatrowych na zdrowie ludzi. Jednak realizacja tego ostatniego celu odbywa się z naruszeniem zasady proporcjonalności środków do zamierzonych celów.

\section{- 2. Wzorce kontroli}

2.1. Artykuł 22 Konstytucji („Ograniczenie wolności działalności gospodarczej jest dopuszczalne tylko w drodze ustawy i tylko ze względu na ważny interes publiczny”) wyznacza granice ingerencji w sferę wolności działalności gospodarczej. Wolność działalności gospodarczej - jako zasada konstytucyjna - jest z kolei statuowana w art. 20 ustawy zasadniczej, stąd oba przepisy powinny być odczytywane łącznie. Przy czym szersze odniesienie się w tym miejscu do art. 20 Konstytucji znajduje uzasadnienie również z tego względu, że ten ostatni został przywołany przez obu wnioskodawców jako wzorzec kontroli w odniesieniu do znacznej części przepisów zaskarżonych w niniejszym postępowaniu.

Artykuł 20 Konstytucji wyznacza podstawy ustroju gospodarczego Rzeczypospolitej („Społeczna gospodarka rynkowa oparta na wolności działalności gospodarczej, własności prywatnej oraz solidarności, dialogu i współpracy partnerów społecznych stanowi podstawę ustroju gospodarczego Rzeczypospolitej Polskiej”). W świetle cytowanego przepisu konstytucyjnymi cechami pożądanego przez ustrojodawcę modelu gospodarki są: wolność gospodarcza, własność prywatna oraz solidarność, dialog i współpraca partnerów społecznych. W piś- 
miennictwie wskazuje się, że: „[p]rzepis ten wyraża normę-zasadę adresowaną do wszelkich władz publicznych i wyznaczającą im powinność takiego ukształtowania ustroju gospodarczego, w drodze przyjmowania odpowiednich regulacji prawnych, tworzenia warunków gospodarowania czy instytucji społecznych, by odpowiadał wizji społecznej gospodarki rynkowej przyjętej przez ustrojodawcę" (L. Garlicki, M. Zubik, Komentarz do art. 20 [w:] Konstytucja Rzeczypospolitej Polskiej. Komentarz, t. I, red. L. Garlicki, M. Zubik, Warszawa 2016, s. 517).

Kierunek interpretacji zasady wyrażonej w art. 20 Konstytucji oddaje następujące stanowisko Trybunału Konstytucyjnego: „Rozważany art. 20 Konstytucji nakłada [...] obowiązek kształtowania i realizowania społecznej gospodarki rynkowej (podejmowania decyzji dotyczących ładu społeczno-gospodarczego) w oparciu o solidarność, dialog i współpracę partnerów społecznych. Adresatem tego obowiązku są władze publiczne oraz takie podmioty jak związki zawodowe, inne organizacje reprezentujące producentów i drobnych wytwórców, organizacje pracodawców, samorząd gospodarczy. Podejmując decyzje dotyczące ładu społecznego i gospodarczego, należy zatem dążyć do wspólnego ustalenia ich treści, równoważącego niezgodne interesy poszczególnych partnerów społecznych. sformułowanie rozstrzygnięcia, równomiernie rozkładającego ustępstwa i korzyści. [...] W wymiarze proceduralnym «solidarność, dialog i współpraca» nakazują stworzenie negocjacyjnego sposobu rozstrzygania spraw spornych, form wymiany informacji, prezentacji stanowisk, instytucjonalnych gwarancji dyskursu społecznego" (wyrok TK z 7 maja 2014 r., sygn. akt K 43/12).

Pojęcie „działalności gospodarczej” nie zostało zdefiniowane w Konstytucji. W orzecznictwie TK przyjmuje się, że obejmuje ono działalność, której zasadniczym celem jest osiągnięcie zysku. Chodzi tu więc o działalność, która ma z założenia zarobkowy charakter, a przy tym jest wykonywana w sposób ciągły i profesjonalny (zob. np. wyrok TK z 19 stycznia 2010 r., sygn. akt SK 35/08). Uznaje się ponadto, że: „[Z] użycia w art. 20 i art. 22 Konstytucji zwrotu «wolność działalności gospodarczej» wynika, że chodzi o działalność jednostek (osób fizycznych) oraz instytucji «niepaństwowych» (czy też - szerzej rzecz ujmując niepublicznych), które mają prawo do samodzielnego decydowania o udziale w życiu gospodarczym, zakresie i formach tego udziału, w tym możliwie swobodnego podejmowania różnych działań faktycznych i prawnych, mieszczących się w ramach prowadzenia działalności gospodarczej. W rezultacie wolność gospodarcza stanowi przedmiotowo wiązkę swobód obejmujących podejmowanie, organizację i wykonywanie działalności w tej sferze" (wyrok TK z 7 maja 2001 r., sygn. akt K 19/00).

Z kolei art. 22 Konstytucji określa przesłanki ograniczenia wolności działalności gospodarczej. Przepis ten przewiduje dwie takie przesłanki - formalną („tylko w drodze ustawy”) i materialną („tylko ze względu na ważny interes publiczny”). W orzecznictwie sądu konstytucyjnego przyjmuje się, że wymienione przesłanki nie prowadzą do wyłączenia obowiązywania w odniesieniu do wolności działal- 
ności gospodarczej zasady proporcjonalności, wyrażonej w art. 31 ust. 3 Konstytucji. Wskazuje się w tym kontekście, że: „Art. 22 Konstytucji jako lex specialis nie wyłącza jednak zupełnie stosowania art. 31 ust. 3 Konstytucji, przynajmniej w tym zakresie, w jakim «ważny interes publiczny» może być odniesiony odpowiednio do zasady proporcjonalności, wynikającej z art. 31 ust. 3 Konstytucji” (wyrok TK z 11 marca 2015 r., sygn. akt P 4/14). W odniesieniu do zawartej w art. 22 Konstytucji klauzuli „ważnego interesu publicznego” sąd konstytucyjny zauważa, że obejmuje ona wszystkie przesłanki materialne wymienione w art. 31 ust. 3 Konstytucji, a ponadto, w zakresie owego interesu mieszczą się też inne wartości, niewskazane w generalnej klauzuli ograniczającej. W rezultacie, zakres dopuszczalnych ograniczeń wolności działalności gospodarczej jest - przynajmniej z punktu widzenia materialnoprawnych przesłanek ograniczeń - szerszy od zakresu ograniczeń tych wolności i praw, do których odnosi się art. 31 ust. 3 Konstytucji (zob. np. wyrok TK z 13 października 2010 r., sygn. akt Kp 1/09).

2.2. Wyrażona w art. 31 ust. 3 Konstytucji zasada proporcjonalności („Ograniczenia w zakresie korzystania z konstytucyjnych wolności i praw mogą być ustanawiane tylko w ustawie i tylko wtedy, gdy są konieczne w demokratycznym państwie dla jego bezpieczeństwa lub porządku publicznego, bądź dla ochrony środowiska, zdrowia i moralności publicznej, albo wolności i praw innych osób. Ograniczenia te nie mogą naruszać istoty wolności i praw”) określa przesłanki, od których spełnienia uzależniona została możliwość wprowadzenia ograniczeń w sferze wolności i praw człowieka. Zasada ta stanowiła wielokrotnie przedmiot szczegółowej analizy w orzecznictwie Trybunału Konstytucyjnego (zob. np. wyroki TK z: 24 kwietnia 2018 r., sygn. akt SK 27/16; 5 grudnia 2018 r., sygn. akt K 6/17), przy czym jest ona interpretowana w jednolity sposób.

Sformułowane w art. 31 ust. 3 Konstytucji przesłanki ograniczenia konstytucyjnych wolności i praw mają charakter formalny (odnoszą się do rodzaju aktu, wprowadzającego ograniczenia), jak i materialny (dotyczą treści wprowadzonych ograniczeń). Do wymogów formalnych zalicza się dopuszczalność ustanowienia ograniczeń „tylko w ustawie”. Natomiast wymogiem materialnym jest konieczność wprowadzenia ograniczeń w demokratycznym państwie prawnym ze względu na zapewnienie jego bezpieczeństwa i porządku publicznego, ochrony środowiska, zdrowia i moralności publicznej, albo wolności i praw innych osób. Ponadto, ograniczenia te nie mogą naruszać istoty wolności i praw.

Zasada proporcjonalności wyznacza granice, w których ograniczeniom mogą podlegać konstytucyjne prawa i wolności jednostki. Ocena spełnienia wskazanych wymogów następuje przy wykorzystaniu tzw. testu proporcjonalności, obejmującego odpowiedź na następujące pytania: 1) czy wprowadzona regulacja jest w stanie doprowadzić do zamierzonych przez nią skutków; 2) czy regulacja ta jest niezbędna dla ochrony interesu publicznego, z którym jest powiązana; 3) czy efekty wprowadzonej regulacji pozostają w proporcji do ciężarów nakładanych przez nią na obywatela (np. wyrok TK z 12 stycznia 2000 r., sygn. akt P 11/98). 
Przesłanka proporcjonalności w znaczeniu ścisłym, wyrażona w pkt 3 testu proporcjonalności, oznacza obowiązek wyboru przez prawodawcę najmniej dolegliwego środka realizacji określonego interesu (wartości) podlegającego konstytucyjnej ochronie. Ocena jej spełnienia (a także pozostałych przesłanek objętych testem proporcjonalności) wymaga w każdym konkretnym przypadku skonfrontowania wartości i dóbr chronionych daną regulacją z tymi, które w jej efekcie podlegają ograniczeniu. Przepis wprowadzający ograniczenie jest niezgodny z Konstytucją, jeżeli te same efekty można osiągnąć za pomocą środków, które w mniejszym zakresie ograniczają korzystanie z wolności lub prawa podmiotowego. Trybunał Konstytucyjny podkreśla, że istotą tak rozumianego nakazu nadmiernej ingerencji jest uznanie, że ustawodawca nie może ustanawiać ograniczeń przekraczających pewien stopień uciążliwości, a zwłaszcza naruszających proporcję między stopniem naruszenia uprawnień jednostki a rangą interesu publicznego, który ma w ten sposób podlegać ochronie (np. wyrok TK z 22 lutego 2005 r., sygn. akt K 10/04). Przy ocenie, czy zakaz nadmiernej ingerencji został naruszony, należy uwzględnić specyfikę poszczególnych praw i wolności - w porównaniu z prawami ekonomicznymi i socjalnymi zaostrzone standardy dotyczą praw osobistych i politycznych, (zob. orzeczenie TK z 26 kwietnia 1995 r., sygn. akt K 11/94).

Ograniczenia wynikające $z$ art. 31 ust. 3 Konstytucji mają charakter uniwersalny, dotyczą bowiem wszystkich konstytucyjnych wolności i praw (zob. wyrok TK z 21 lipca 2010 r., sygn. akt SK 21/08).

2.3. Artykuł 32 ust. 1 Konstytucji wyraża na poziomie ustawy zasadniczej zasadę równości. Przepis ten ma następujące brzmienie: „Wszyscy są wobec prawa równi. Wszyscy mają prawo do równego traktowania przez władze publiczne”.

Zgodnie z utrwalonym orzecznictwem Trybunału Konstytucyjnego zasada równości nakazuje identyczne traktowanie podmiotów znajdujących się w takiej samej lub zbliżonej sytuacji prawnie relewantnej. Równe traktowanie oznacza przy tym traktowanie według jednakowej miary, bez zróżnicowań tak dyskryminujących, jak i faworyzujących. Obowiązek równego traktowania odnosi się do podmiotów prawa charakteryzujących się wspólną cechą, istotną z punktu widzenia danej regulacji prawnej (zob. wyroki TK z: 4 kwietnia 2017 r., sygn. akt P 56/14; 28 czerwca 2017 r., sygn. akt P 63/14; 12 grudnia 2017 r., sygn. akt SK 13/15 i 13 grudnia 2017 r., sygn. akt SK 48/15). Cechą wspólną decydującą o podobieństwie danej grupy podmiotów może być zarówno cecha faktyczna, jak i prawna, a ustalenia jej istnienia dokonuje się z uwzględnieniem treści i celu przepisów, w których zawarta jest kontrolowana norma (np. orzeczenie TK z 3 września 1996 r., sygn. akt K 10/96). Równość oznacza jednocześnie akceptację różnego traktowania przez prawo różnych podmiotów (adresatów norm prawnych) i nie oznacza tożsamości (identyczności) praw wszystkich jednostek. Zasada równości nie ma charakteru absolutnego - dopuszczalne są pewne odstępstwa od jej realizacji pod warunkiem, że istnieją szczególne względy, znaj- 
dujące uzasadnienie w innych wartościach konstytucyjnych. Ponadto z zasady równości nie wynika wymóg zagwarantowania podmiotom prawa konkretnych uprawnień czy też zakaz nakładania na podmioty konkretnych obowiązków.

Ocena zgodności przepisu poddanego kontroli z zasadą równości wymaga, po pierwsze, ustalenia, czy można wskazać wspólną cechę istotną określonych podmiotów, co następuje na podstawie treści i celu aktu normatywnego, w którym została zawarta kontrolowana norma prawna. Po drugie, należy ocenić, czy prawodawca zróżnicował prawa lub obowiązki podmiotów znajdujących się w takiej samej lub podobnej sytuacji prawnie relewantnej. Po trzecie, trzeba rozważyć, czy wprowadzone przez prawodawcę odstępstwa można uznać za konstytucyjnie dozwolone. Ocena, czy odstępstwa te są dozwolone, wymaga z kolei udzielenia odpowiedzi na następujące pytania: 1) czy odstępstwa mają charakter relewantny; 2) czy odstępstwa odpowiadają wymogom wynikającym z zasady proporcjonalności; 3) czy odstępstwa pozostają w związku z innymi zasadami konstytucyjnymi i chronionymi przez nie wartościami, uzasadniającymi odmienne traktowanie podmiotów podobnych (tzw. test równości; np. wyrok TK z 18 marca 2014 r., sygn. akt SK 53/12).

\section{- 3. Ocena konstytucyjności}

3.1. Odnosząc się do zarzutów Wnioskodawcy II, należy na wstępie zauważyć, że stan prawny obowiązujący przed wejściem w życie ustawy o inwestycjach, w świetle którego ustalenie lokalizacji elektrowni wiatrowej następuje w drodze decyzji o warunkach zabudowy, a nie na podstawie miejscowego planu zagospodarowania przestrzennego, nie może być uznany za niepożądany. Wynika to z trzech podstawowych przyczyn. Po pierwsze, decyzja w sprawie warunków zabudowy ma charakter wycinkowy, w toku jej wydawania następuje bowiem wyłącznie ocena oddziaływania planowanej inwestycji na sąsiadujące $\mathrm{z}$ nią nieruchomości zgodnie z zasadą dobrego sąsiedztwa. Ze względu na znaczną swobodę $\mathrm{w}$ interpretacji warunku dobrego sąsiedztwa ocena zgodności zamierzenia budowlanego z zabudową znajdującą się w bezpośrednim sąsiedztwie odznacza się $\mathrm{w}$ istotnym stopniu uznaniowością. Natomiast w przypadku miejscowego planu zagospodarowania przyjęte w nim ustalenia dotyczące cech zabudowy mają charakter kompleksowy i dotyczą całego obszaru objętego planem. Stąd też nie ma wątpliwości, że co do zasady przedsięwzięcia budowlane powinny być prowadzone na podstawie ustaleń zawartych w planach miejscowych. Dopuszczenie realizacji takich przedsięwzięć na podstawie decyzji o warunkach zabudowy jest ułomne i zostało przewidziane wyłącznie dla umożliwienia zabudowy terenów, które nie są objęte planami miejscowymi.

Po drugie, oddziaływanie elektrowni wiatrowej na otoczenie rozciąga się znacznie poza obszar, dla którego przeprowadzana jest ocena zgodności planowanej inwestycji z zabudową sąsiednią przeprowadzaną przy wydawaniu decyzji o warunkach zabudowy. Wskazuje to jednoznacznie, że procedura ustalania 
lokalizacji przedsięwzięcia polegającego na budowie elektrowni wiatrowej na podstawie warunków zabudowy jest nieadekwatna. W szczególności zastosowanie zasady dobrego sąsiedztwa $\mathrm{w}$ przypadku ustalania lokalizacji elektrowni wiatrowych jest dalece niewystarczające, skoro zasada ta oparta jest na analizie cech zabudowy działek sąsiednich (zob. art. 61 ust. 1 pkt 1 ustawy o planowaniu). $\mathrm{Z}$ kolei w praktyce na działkach tych niezmiernie rzadko występuje zabudowa odznaczająca się gabarytami czy innymi cechami typowymi dla elektrowni wiatrowych. Z tych względów obiektywnie niemożliwe jest spełnienie warunku, aby planowana elektrownia wiatrowa miała stanowić kontynuację zabudowy występującej już na działkach sąsiednich. Ponadto ograniczenie obszaru poddanego analizie do działek sąsiednich, co jest cechą charakteryzującą postępowanie w sprawie ustalenia warunków zabudowy, musi być uznane za nietrafne, skoro oddziaływanie elektrowni wiatrowej na otoczenie, krajobraz i środowisko rozciąga się zwykle daleko poza sąsiednie działki.

Wreszcie, po trzecie, miejscowy plan jest uchwalany w szczególnej procedurze. Prace nad planem toczą się w sposób transparentny, mogą w nich wziąć udział mieszkańcy, jak również inne podmioty (w tym podmioty planujące podjąć na działkach objętych planem działalność w zakresie elektrowni wiatrowych). Wszystkie te podmioty, w tym mieszkańcy, mogą zgłaszać propozycje i uwagi do rozwiązań przyjętych $\mathrm{w}$ planie. $\mathrm{W}$ ten sposób procedura planistyczna zapewnia uwzględnienie różnych interesów. Nade wszystko jednak plan miejscowy jest aktem podejmowanym przez wspólnotę samorządową, stanowiąc wyraz jej woli co do kierunków zagospodarowania terenów na obszarze objętym planem. Powyższe uwarunkowania nie są natomiast realizowane w sytuacji, gdy dopuszczalne jest podejmowanie decyzji o lokalizacji elektrowni wiatrowych na podstawie jednostkowych decyzji o warunkach zabudowy. $\mathrm{W}$ tej bowiem procedurze uwzględnieniu podlega, co do zasady, jedynie prawnie chroniony interes osób zamieszkałych na działkach bezpośrednio przylegających do działki, na których ma zostać wybudowana elektrownia.

Wskazane argumenty przesądzają o tym, że wprowadzenie przez ustawodawcę zasady dopuszczającej lokalizację elektrowni wiatrowej wyłącznie na podstawie miejscowego planu zagospodarowania jest rozwiązaniem zasadnym. Tylko w ten sposób zabezpieczone będą interesy lokalnej społeczności, która bez wątpienia ma interes we współdecydowaniu, czy obiekty o tak znacznym stopniu oddziaływania na otoczenie jak elektrownie wiatrowe będą funkcjonować na obszarze gminy. Warto zauważyć, że dotychczas lokalizacja elektrowni wiatrowych wywoływała protesty, nierzadko uzasadnione, okolicznych mieszkańców. Ich uniknięciu służy wprowadzenie wymogu ustalenia w miejscowym planie przeznaczenia określonych terenów na lokalizację elektrowni wiatrowych.

Warto też zauważyć, że obowiązujący przed wejściem ustawy o inwestycjach reżim prawny, w świetle którego lokalizacja elektrowni wiatrowej następowała na podstawie decyzji o warunkach zabudowy, wywoływała wiele wątpliwo- 
ści. W wystąpieniu Rzecznika Praw Obywatelskich z 3 lutego 2016 r. (sygn. akt IV.7006.271.2014.MCH) wskazano na liczne nieprawidłowości w zakresie lokalizacji elektrowni wiatrowych, w tym w szczególności poruszono problematykę lokalizowania elektrowni wiatrowych na podstawie decyzji o warunkach zabudowy. Wskazano, że lokalizacja elektrowni w tym trybie odbywa się bez zaangażowania społeczności lokalnej i zapewnienia jej wpływu na proces lokalizacji. Zbyt wąsko jest także zakreślony krąg podmiotów uznawanych za strony tak w postępowaniu lokalizacyjnym, jak i w postępowaniu w sprawie wydania pozwolenia na budowę.

Sejm zgadza się z argumentem, że wymóg określenia w planie miejscowym przeznaczenia danego terenu na lokalizację elektrowni wiatrowej skutkować będzie ograniczeniem dostępności terenów, na których instalacje te będą mogły być budowane. Wynika to z fragmentarycznego pokrycia obszaru państwa planami miejscowymi, przy czym tereny słabo zurbanizowane, a na takich lokalizowane są elektrownie wiatrowe, zazwyczaj pozbawione są planów. Zauważyć jednak trzeba, że nie jest to stan niezmienny. Jeśli dana gmina jest zainteresowana lokalizacją na swoim obszarze elektrowni wiatrowej (elektrowni wiatrowych), wówczas realizacji tego celu służy właśnie wdrożenie procedury planistycznej i dopuszczenie lokalizacji elektrowni wiatrowych.

3.2. Przystępując do szczegółowej oceny zasadności zarzutów Wnioskodawcy II, należy w pierwszej kolejności rozważyć, czy przepisy dopuszczające lokalizację elektrowni wiatrowej wyłącznie na obszarach, dla których został ustanowiony miejscowy plan zagospodarowania przestrzennego stanowią ingerencję w sferę wolności wykonywania działalności gospodarczej.

Wprowadzenie wymogu obowiązywania dla danego obszaru planu miejscowego, jako warunku lokalizacji elektrowni wiatrowej, należy postrzegać przede wszystkim jako regulację z zakresu prawa budowlanego oraz planowania przestrzennego. Elektrownia wiatrowa stanowi bowiem obiekt budowlany, którego lokalizacja jest dopuszczalna pod warunkiem spełnienia wymogów określonych w prawie budowlanym. Zasady i ograniczenia w tym względzie dotyczą każdego podmiotu, który planuje inwestycję w zakresie elektrowni wiatrowych, także na własne potrzeby, o ile tylko planowana instalacja przekracza moc mikroinstalacji $(40 \mathrm{~kW})$. Stąd też kwestionowane przepisy nie tyle reglamentują prowadzenie działalności gospodarczej w sferze elektrowni wiatrowych, ile precyzują zasady lokalizacji elektrowni wiatrowych jako obiektów budowlanych. Jeżeli podmiot gospodarczy zamierza prowadzić działalność w sferze elektrowni wiatrowych, to $\mathrm{w}$ kwestii ustalenia lokalizacji tych elektrowni pozostaje związany regulacjami prawa budowlanego oraz przepisami z zakresu planowania przestrzennego, określającymi zasady ich sytuowania. Nie są to jednak ograniczenia dotykające bezpośrednio swobody działalności gospodarczej.

Należy zwrócić uwagę, że podejmowanie działalności - w różnych sferach może być uzależnione od spełnienia określonych wymogów, np. w zakresie 
ochrony środowiska. Nie ma przy tym znaczenia, czy czynności te są realizowane w ramach działalności gospodarczej, obowiązek podporządkowania się tym wymogom w równym stopniu obejmuje bowiem również osoby fizyczne. Zarazem, jeżeli podjęcie tychże czynności następuje w ramach prowadzonej działalności gospodarczej, to nałożenie powyższego obowiązku nie powinno być postrzegane - z punktu widzenia prawnego - jako skutkujące ograniczeniem swobody działalności gospodarczej. Ilustracją powyższego jest sytuacja, w której podjęcie określonych przedsięwzięć skutkujących oddziaływaniem na środowisko jest uzależnione od uprzedniego wydania decyzji środowiskowej. W tym kontekście wprowadzenie wymogu uzyskania takiej decyzji nie stanowi prawnego przejawu ograniczenia swobody działalności gospodarczej, nawet jeśli z subiektywnego punktu widzenia mogłoby być tak odbierane. Przechodząc na płaszczyznę problematyki lokalizacji elektrowni wiatrowych, trzeba zauważyć, że formą ograniczenia działalności gospodarczej w tej sferze byłoby natomiast - bez wątpienia ustanowienie wymogu uzyskania zgody (zezwolenia, koncesji) na prowadzenie działalności tego rodzaju. Żadnego takiego ograniczenia kwestionowane przepisy jednak nie przewidują.

Na tym tle należy uznać, że kwestionowane przepisy nie mogą być uznane za skutkujące ograniczeniem swobody działalności gospodarczej w znaczeniu, jakie nadaje jej art. 20 i art. 22 Konstytucji. Wolność ta oznacza swobodę działalności jednostek oraz tworzonych przez nie struktur, mających prawo samodzielnego decydowania o udziale $\mathrm{w}$ życiu gospodarczym, o zakresie i formach tego udziału, w tym swobodnego podejmowania działań faktycznych i prawnych. Reglamentacja zasad sytuowania elektrowni wiatrowych jako obiektów budowlanych nie stanowi ograniczenia tak rozumianej wolności działalności gospodarczej. Trzeba mieć także na względzie, że ewentualny brak możliwości lokalizacji elektrowni wiatrowych wynika $\mathrm{w}$ tym wypadku z przyczyn faktycznych, a więc $\mathrm{z}$ braku uchwalenia dla danego obszaru miejscowego planu zagospodarowania przestrzennego. Jest to przy tym przeszkoda o charakterze względnym, skoro dla obszaru, na którym inwestor planuje lokalizację elektrowni, może zostać uchwalony miejscowy plan zagospodarowania, może to także nastąpić na wniosek inwestora. Dlatego należy uznać nieadekwatność art. 22 Konstytucji jako wzorca kontroli dotyczącego art. 3 ustawy.

Niezależnie od powyższego warto zwrócić uwagę na dwie inne kwestie. Po pierwsze, wbrew twierdzeniom Wnioskodawcy II, elektrownie wiatrowe nie stanowią jedynego obiektu, którego lokalizacja (budowa) jest możliwa wyłącznie w przypadku obowiązywania dla danego obszaru miejscowego planu zagospodarowania przestrzennego. Przykład tego typu ograniczeń stanowią regulacje dotyczące lokalizacji obiektów handlowych o powierzchni sprzedaży powyżej $2000 \mathrm{~m}^{2}$. Zgodnie $\mathrm{z}$ art. 10 ust. 3b ustawy o planowaniu budowa tego rodzaju obiektów handlowych może nastąpić wyłącznie na podstawie miejscowego planu zagospodarowania przestrzennego. Ponadto ich lokalizacja na terenie gminy 
musi być także przewidziana w studium uwarunkowań i kierunków zagospodarowania przestrzennego (zob. art. 10 ust. 3a ustawy o planowaniu).

Po drugie, przedsiębiorca prowadzący działalność gospodarczą w zakresie elektrowni wiatrowej nie doznaje ograniczeń co do możliwości podjęcia tej działalności, a jedynie lokalizacja, w której ma być podjęta ta działalność, ma się odznaczać określonymi cechami, a więc musi obowiązywać dla niej miejscowy plan zagospodarowania przestrzennego, dopuszczający elektrownie wiatrowe. W większości przypadków podmioty prowadzące działalność w zakresie budowy i eksploatacji elektrowni wiatrowych nie są właścicielami nieruchomości, na których ma być prowadzona ta działalność. Tym samym o ograniczeniu w podjęciu działalności gospodarczej można mówić wyłącznie w wymiarze faktycznym i wynika ono z wyboru prowadzenia takiej działalności w lokalizacji, dla której nie został uchwalony miejscowy plan zagospodarowania.

3.3. W ocenie Wnioskodawcy II art. 3 ustawy jest także niezgodny z zasadą równości. Odnosząc się do powyższego zarzutu, warto zauważyć, że naruszenie zasady równości wymaga wykazania, że określona grupa podmiotów została poddana określonym ograniczeniom i jednocześnie ograniczenia te nie odnoszą się do innej grupy podmiotów, mimo że obie grupy odznaczają się wspólną cechą relewantną. Przesądza to, że ta ostatnia grupa jest traktowana przez ustawodawcę w inny (bardziej korzystny) sposób od podmiotów, które zostały poddane ograniczeniom. Wnioskodawca II nie wskazał jednak ani grupy podmiotów, które traktowane są w inny (uprzywilejowany sposób) w stosunku do podmiotów prowadzących działalność gospodarczą w zakresie budowy elektrowni wiatrowych, ani też nie wskazał cechy relewantnej. Na tym tle można co najwyżej przyjąć, że zróżnicowanie obejmuje z jednej strony podmioty prowadzące działalność w zakresie elektrowni wiatrowych, z drugiej zaś podmioty prowadzące działalność we wszystkich pozostałych obszarach, z wyłączeniem elektrowni wiatrowych. Natomiast cechą relewantną jest prowadzenie działalności gospodarczej.

Powołana przez Wnioskodawcę II argumentacja nie jest adekwatna dla oceny kwestionowanych przepisów z punktu widzenia konstytucyjnej zasady równości. Przede wszystkim w uzasadnieniu powyższego zarzutu nazbyt szeroko została zakreślona grupa podmiotów odznaczających się wspólną cechą relewantną. W tym względzie trzeba zauważyć, że w stosunku do wielu sfer działalności gospodarczej ustawodawca wprowadził różne ograniczenia. Trudno zatem porównywać ograniczenia dotyczące prowadzenia działalności w sferze budowy i eksploatacji elektrowni wiatrowej z działalnością polegającą np. na przetwarzaniu odpadów komunalnych. W każdej z tych sfer istnieją odrębne ograniczenia, właściwe dla danego profilu działalności gospodarczej.

Uwzględniając powyższe ustalenia, należy wskazać, że brak jest podstaw do uznania adekwatności podniesionego przez Wnioskodawcę II zarzutu dotyczącego naruszenia art. 32 ust. 1 Konstytucji. 
3.4. Wprowadzenie ograniczeń $\mathrm{w}$ sferze wolności działalności gospodarczej Wnioskodawca II powiązał także z naruszeniem zasady proporcjonalności (art. 31 ust. 3 Konstytucji). Uzasadnienie w tym względzie jest lakoniczne i sprowadza się do stwierdzenia, że wprawdzie środki zastosowane przez prawodawcę są w stanie doprowadzić do zamierzonych celów, jednak ich efekty pozostają w jaskrawej dysproporcji w stosunku do ciężarów nakładanych na obywatela.

W pkt 3.2 stanowiska przyjęto, że zasada wolności działalności gospodarczej nie jest adekwatnym wzorcem kontroli dla oceny dopuszczalności wprowadzenia zasady uzależniającej budowę elektrowni wiatrowej od uchwalenia dla danego obszaru miejscowego planu zagospodarowania przestrzennego. Powyższe ustalenie przekłada się na ocenę konstytucyjności art. 3 ustawy o inwestycjach z punktu widzenia zasady proporcjonalności. W tym kontekście warto zauważyć, że Wnioskodawca II potraktował art. 31 ust. 3 Konstytucji jako uzupełniający wzorzec $\mathrm{w}$ stosunku do art. 22 Konstytucji. W tym ujęciu art. 31 ust. 3 Konstytucji ma bowiem wyznaczać dodatkowe kryteria oceny, z punktu widzenia których należy dokonać oceny dopuszczalności ograniczeń w sferze wolności działalności gospodarczej. Uznając, że dla oceny kwestionowanego przepisu zasada wolności działalności gospodarczej nie jest adekwatnym wzorcem kontroli, tożsame ustalenie trzeba przyjąć względem art. 31 ust. 3 Konstytucji.

3.5. Mając na uwadze powyższe, Sejm wnosi o uznanie, że art. 3 ustawy nie jest niezgodny $z$ art. 22 , art. 31 ust. 3 i art. 32 ust. 1 Konstytucji.

\section{Minimalna odległość elektrowni wiatrowej od zabudowy mieszkaniowej (kryterium 10H)}

\section{- 1. Zarzuty wnioskodawców}

1.1. Kolejna grupa zarzutów dotyczy przyjętego w ustawie o inwestycjach wymogu zachowania minimalnej odległości od zabudowy mieszkaniowej, w jakiej może być lokalizowana elektrownia wiatrowa (kryterium 10H). Zarzuty w tym zakresie zostały sformułowane przez obu wnioskodawców.

1.2. Zdaniem Wnioskodawcy I kryterium odległościowe zostało przyjęte przez ustawodawcę arbitralnie i nie znajduje oparcia w badaniach naukowych. Jednocześnie, poza wysokością elektrowni, ustawodawca nie uwzględnił żadnych innych parametrów inwestycji (np. moc elektrowni, ukształtowanie terenu, przeciętna prędkość i kierunek wiatru), od których zależy natężenie immisji wywoływanych przez elektrownie wiatrowe. Jak podkreślono, limity odległościowe dotyczą w sposób generalny wszystkich zamierzeń inwestycyjnych z zakresu elektrowni wiatrowych, także gdy w przypadku konkretnej inwestycji jej oddziaływanie na życie i zdrowie ludzi oraz na środowisko nie wymagałoby przyjęcia kryterium $10 \mathrm{H}$. Stąd kryterium to jest nieadekwatne, zwłaszcza jeśli uwzględnić stopień wynikającej z niego ingerencji w sferę praw inwestorów. 
Wnioskodawca I zakwestionował wyniki analiz, na podstawie których ustawodawca przyjął kryterium $10 \mathrm{H}$. Jak wskazał, w zdecydowanej większości zagranicznych opracowań naukowych przyjmuje się, że hipotetyczna odległość, na jaką mogą upaść uszkodzone fragmenty łopat czy też kawałki lodu oderwane z łopat wynosi nie więcej niż trzykrotna wysokość elektrowni wiatrowej. W kwestionowanych przepisach przyjęto natomiast ponadtrzykrotnie większą odległość.

Średnia wysokość elektrowni wiatrowych budowanych w Polsce, liczona w najwyższym położeniu wirnika, wynosi 150-200 m. Zastosowanie kryterium $10 \mathrm{H}$ oznacza, że strefa ochronna wokół takiej elektrowni wynosi od 1500 do 2000 m. Ze względu na rozproszony charakter zabudowy występującej w Polsce możliwość sytuowania elektrowni wiatrowych została ograniczona do bardzo niewielkich obszarów, tj. - wedle różnych szacunków - od 0,5 do 2,5\% powierzchni kraju. Jeszcze mniejsza jest liczba potencjalnych lokalizacji w przypadku elektrowni wiatrowych odznaczających się znaczną wysokością, tj. ponad $150 \mathrm{~m}$. Na tym tle, zdaniem Wnioskodawcy I, kwestionowane przepisy są niezgodne z zasadą proporcjonalności (art. 2 Konstytucji), z zasadą zrównoważonego rozwoju (art. 5 Konstytucji), z zasadą społecznej gospodarki rynkowej i wolnością działalności gospodarczej (art. 20 i art. 22 Konstytucji), prawem własności (art. 64 ust. 1-3 Konstytucji) oraz z zasadą równości (art. 32 ust. 1 Konstytucji).

Naruszenie zasady proporcjonalności Wnioskodawca I powiązał z tym, że przyjęcie kryterium $10 \mathrm{H}$ nie jest konieczne dla realizacji celu, któremu służyć mają regulacje wprowadzone ustawą o inwestycjach, a więc ochronie życia i zdrowia ludzi oraz ochronie środowiska. Omawiane rozwiązanie nie jest zatem niezbędne do osiągnięcia celów założonych przez ustawodawcę, co więcej, nie zapewnia ich realizacji. W warunkach istniejącej w Polsce rozproszonej zabudowy kryterium $10 \mathrm{H}$, nieuwzględniające rzeczywistego oddziaływania danej inwestycji na otoczenie, jest niemal jednoznaczne z zakazem budowy elektrowni wiatrowych.

Uzasadniając naruszenie zasady zrównoważonego rozwoju, Wnioskodawca I stwierdził, że kwestionowane przepisy nie wyważają należycie wartości, jakimi są: zapewnienie wolności i praw człowieka oraz bezpieczeństwa obywateli, ochrona środowiska oraz rozwój państwa w zakresie pozyskiwania odnawialnych źródeł energii. Ograniczenia w zakresie budowy elektrowni wiatrowych są restrykcyjne i oderwane od rzeczywistych potrzeb, hamują rozwój energetyki wiatrowej i w konsekwencji rozwój odnawialnych źródeł energii w Polsce. Jednocześnie analogiczne kryteria nie zostały wprowadzone w przypadku elektrowni konwencjonalnych. Ponadto kryterium $10 \mathrm{H}$ powoduje, że w miejsce nowoczesnych wysokich elektrowni wiatrowych o dużej mocy budowane będą niskie, nieefektywne elektrownie starszego typu.

W związku z zarzutem niezgodności kwestionowanych przepisów z art. 20 i art. 22 Konstytucji wnioskodawca wskazał, że wprowadzone ustawą ogranicze- 
nie swobody działalności gospodarczej nie znajduje oparcia w ważnym interesie publicznym. Kryterium $10 \mathrm{H}$ służy ochronie interesów wąskiej grupy osób, tj. zamieszkałych $\mathrm{w}$ bezpośrednim sąsiedztwie elektrowni wiatrowych i z tego względu ograniczenie to nie może być traktowane jako wprowadzone w ważnym interesie publicznym. Ustawa o inwestycjach nie służy ochronie środowiska, hamując rozwój odnawialnych źródeł energii. Nadto Wnioskodawca I stwierdził, że ograniczenie wolności działalności gospodarczej w omawianej sferze ma charakter nieproporcjonalny. Istnieją bowiem inne skuteczne metody zapewnienia ochrony zdrowia i życia ludzi oraz ochrony środowiska. Przy czym ocena rzeczywistego oddziaływania zamierzonej inwestycji na okolicznych mieszkańców oraz na środowisko zawsze powinna mieć charakter zindywidualizowany, uwzględnić zarówno konkretne parametry planowanej elektrowni, jak i czynniki środowiskowe.

W odniesieniu do zarzutu naruszenia prawa własności Wnioskodawca I stwierdził, że kwestionowane przepisy ingerują w prawo własności i inne prawa majątkowe inwestorów zamierzających lokalizować i budować elektrownie wiatrowe. Kryterium $10 \mathrm{H}$ ogranicza prawa inwestorów do przysługujących im nieruchomości w przypadku, jeżeli odległość od istniejących zabudowań mieszkalnych nie spełnia powyższego kryterium. Ograniczenie to przejawia się w zakazie budowy elektrowni wiatrowej na danej nieruchomości. Z kolei ewentualne wybudowanie elektrowni, której wysokość spełniałaby kryterium $10 \mathrm{H}$, byłoby nieuzasadnione ekonomicznie lub technicznie. Wprowadzone kryterium ogranicza również prawa właścicieli nieruchomości niebędących inwestorami, którzy dotąd uprawnieni byli do jej wydzierżawienia/zbycia na rzecz inwestorów.

Zarzut naruszenia zasady równości został powiązany z nieadekwatnym zróżnicowaniem inwestorów $\mathrm{w}$ przysługujących im prawach do korzystania $\mathrm{z}$ nieruchomości. Zróżnicowanie to jest oparte na nieadekwatnym kryterium $(10 \mathrm{H})$, nieuwzględniającym okoliczności konkretnego zamierzenia inwestycyjnego. Wnioskodawca wskazał, że na gruncie zaskarżonych przepisów cechą relewantną jest przymiot bycia inwestorem uprawnionym do dysponowania gruntem na cele budowlane z zamierzeniem lokalizacji i budowy elektrowni wiatrowej. Obowiązywanie kryterium $10 \mathrm{H}$ prowadzi do sytuacji, w której część inwestorów została pozbawiona możliwości lokalizacji i budowy elektrowni wiatrowej na swoim terenie, $\mathrm{z}$ uwagi na położone $\mathrm{w}$ pewnej odległości obiekty chronione. Tym samym ustawodawca zróżnicował pozycję inwestorów dysponujących nieruchomościami przeznaczonymi pod budowę farm wiatrowych, ze względu na istniejące zagospodarowanie otoczenia, bez stosownego uzasadnienia. Przy czym podniesione zróżnicowanie inwestorów, choć w założeniu ma chronić wartości konstytucyjne (ochrona zdrowia i życia ludzi, ochrona środowiska), to jednak w rzeczywistości nie służy osiągnięciu tych celów. Wartości te mogą być chronione również poprzez wprowadzenie innych rozwiązań. Wyznaczenie minimalnej odległości planowanej elektrowni wiatrowej od zabudowy powinno na- 
stępować z uwzględnieniem oddziaływania konkretnej elektrowni i powinno być badane na etapie procesu inwestycyjnego. Ustawodawca powinien doprecyzować lub rozszerzyć regulacje uzależniające dopuszczalność lokalizacji i budowy farmy wiatrowej od okoliczności konkretnego zamierzenia inwestycyjnego, zamiast ograniczać działania inwestorów arbitralnymi przesłankami określonymi na poziomie ustawowym, bez względu na indywidualne uwarunkowania inwestycyjne. Przy czym dotychczasowe instrumenty (wymóg określenia lokalizacji elektrowni o mocy powyżej $40 \mathrm{~kW}$ w studium, decyzja o środowiskowych uwarunkowaniach inwestycji) w należytym stopniu zapewniały ochronę tych wartości. Rozwiązania te miały charakter proporcjonalny i pozwalały na dostosowanie inwestycji do konkretnej lokalizacji.

1.3. Wnioskodawca II wskazał, że - ze względu na rozproszony charakter zabudowy w Polsce - przyjęte w ustawie minimalne odległości między elektrownią wiatrową a zabudową mieszkalną prowadzą do sytuacji, w której w zasadzie wyłączona została możliwość budowy nowych lądowych elektrowni wiatrowych.

Zdaniem Wnioskodawcy II wprowadzenie ograniczeń swobody działalności gospodarczej w sektorze energetyki wiatrowej, jak również ingerencja w uprawnienia właścicielskie (zarówno przedsiębiorców z branży energetyki wiatrowej, jak i właścicieli nieruchomości, którzy planują na nich zabudowę mieszkaniową bądź prowadzą tam działalność gospodarczą) podlega ocenie z punktu widzenia zasady proporcjonalności. Tymczasem żadna z przesłanek określonych w art. 31 ust. 3 Konstytucji nie została spełniona. Ograniczenia wynikające z ustawy o inwestycjach są nadmierne i skutkują brakiem możliwości budowy takich elektrowni. Nie zostały przy tym uwzględnione prawa inwestorów, jak i prawa właścicieli nieruchomości sąsiadujących z nieruchomością, na której powstaje inwestycja. Ustawa niweczy bowiem praktycznie całkowicie możliwość korzystania ze swojego prawa własności przez osoby, które chciałyby na swojej nieruchomości prowadzić określoną działalność gospodarczą oraz właścicieli nieruchomości planujących zabudowę mieszkalną.

Kryteria odległościowe przyjęte w ustawie są, zdaniem Wnioskodawcy II, nietrafne. Jako kryterium, które powinno warunkować lokalizację na określonym obszarze elektrowni wiatrowych, Wnioskodawca II uznał dopuszczalny poziomu hałasu infradźwiękowego. Taka regulacja obowiązuje w większości prawodawstw państw członkowskich UE, które nie wyznaczają w sposób sztywny odległości między elektrownią wiatrową a zabudową mieszkaniową. Nadto, zdaniem Wnioskodawcy II, rzeczywistym celem kwestionowanej ustawy była nie tyle ochrona ludzi przed oddziaływaniem elektrowni wiatrowych, ile ustanowienie faktycznego zakazu ich wznoszenia i prowadzenia w tym zakresie działalności gospodarczej.

Odnosząc się natomiast bezpośrednio do kryterium $10 \mathrm{H}$, Wnioskodawca stwierdził, że jest ono sprzeczne z zasadą proporcjonalności. Wymóg przydatności nie został spełniony, gdyż cel w postaci zwiększenia bezpieczeństwa miesz- 
kańców i tak nie będzie zrealizowany w przypadku już istniejących elektrowni, które nie podlegają dostosowaniu do nowych zasad. W aspekcie niezbędności wprowadzonych ograniczeń za modelowe rozwiązanie Wnioskodawca II uznał regulacje obowiązujące w Danii, przewidujące kryterium 4H (czterokrotność wysokości elektrowni jako minimalna odległość między elektrownią a zabudową mieszkaniową). Oznacza to, że ustawodawca mógł osiągnąć zamierzony cel przy zastosowaniu środków w mniejszym stopniu ingerującym w prawa i wolności jednostki. Ustawa skutkuje wyłączeniem znacznych obszarów kraju z możliwości lokalizacji elektrowni wiatrowych, co prowadzi do naruszenia zasady proporcjonalności sensu stricto.

Kwestionowane przepisy pozostają także niezgodne $\mathrm{z}$ art. 32 ust. 1 i ust. 2 Konstytucji. Ustawodawca w sposób nierówny potraktował przedsiębiorców prowadzących działalność w zakresie elektrowni wiatrowych z przedsiębiorcami prowadzącymi działalność w podobnych branżach (inne rodzaje elektrowni, zakłady przemysłowe, usługowe, środki transportu). Wprowadzony ustawą wymóg minimalnej odległości między elektrownią wiatrową a zabudową mieszkaniową nie występuje w żadnym innym aspekcie działalności wytwórczej, przemysłowej, rolniczej lub usługowej. Z kolei przejawem dyskryminacji jest „różne potraktowanie osób, które chciałyby rozbudowywać zabudowania mieszkalne i elektrownie wiatrowe" (wniosek II, s. 24).

Zdaniem Wnioskodawcy II art. 4 ust. 1 i art. 6-7 ustawy są niezgodne z art. 64 ust. 1 Konstytucji przez nieproporcjonalne ograniczenie prawa własności, a także pozostają w sprzeczności z art. 64 ust. 2 Konstytucji przez zróżnicowanie ochrony praw majątkowych ze względu na charakter podmiotu, któremu te prawa przysługują. Uzasadniając powyższe zarzuty, Wnioskodawca II stwierdził, że: „[s]karżone przepisy Ustawy prowadzą do wyłączenia z możliwości lokowania elektrowni wiatrowych ogromnych obszarów naszego kraju, a z uwagi na już istnienie kilku tysięcy elektrowni w Polsce prowadzą do stworzenia dużych obszarów wyłączonych także z zabudowy mieszkaniowej [...]. Dlatego uchwalone przepisy głęboko ingerują w wykonywanie prawa własności; zarówno w prawo własności elektrowni wiatrowych, jak i w prawo własności gruntów i budynków położonych wokół elektrowni wiatrowych. Przytoczone ograniczenia są nieracjonalne, nieproporcjonalne i dalece niesprawiedliwe. [...] Ustawa nie wprowadziła żadnych możliwości rekompensaty ani dla właścicieli elektrowni wiatrowych dotkniętych zakazem ich rozbudowy, ani dla właścicieli gruntów planujących wznoszenie budynków mieszkalnych lub elektrowni” (wniosek II, s. 22).

Ponadto kwestionowane przepisy naruszają zasadę pomocniczości, którą Wnioskodawca wywodzi z preambuły Konstytucji. Poprzez wprowadzenie na szczeblu ustawowym zasad dotyczących minimalnych odległości, które muszą być zachowane między elektrownią wiatrową a zabudową mieszkaniową gminy utraciły prawo do wpływania na sytuowanie elektrowni wiatrowych na swoim terenie, a także utraciły możliwość kształtowania zabudowy mieszkaniowej wokół 
elektrowni. Do ograniczenia władztwa dochodzi również w sytuacji, gdy elektrownia wiatrowa została usytuowana na terytorium sąsiedniej gminy. Jednocześnie, zdaniem Wnioskodawcy II, kwestionowane przepisy naruszają zasadę równości przez nieuzasadnione konstytucyjnie zróżnicowanie wspólnot lokalnych w zakresie władztwa planistycznego.

\section{Wzorce kontroli}

1. Analiza wzorców kontroli obejmujących art. 20, art. 22, art. 31 ust. 3 i art. 32 ust. 1 Konstytucji została przedstawiona w pkt III.2 stanowiska.

2. Zasada pomocniczości jest wywodzona z preambuły Konstytucji w części, w jakiej zawiera ona następujące sformułowanie: „[...] ustanawiamy Konstytucję Rzeczypospolitej Polskiej jako prawa podstawowe dla państwa oparte [...] na zasadzie pomocniczości umacniającej uprawnienia obywateli i ich wspólnot”.

Treścią zasady pomocniczości (subsydiarności) jest ustalenie podmiotów (struktur, organów, osób), którym powinna być powierzona realizacja określonych spraw (zadań) o charakterze publicznym. Część zadań może i powinna być realizowana bezpośrednio przez podmioty, których zadania te dotyczą, natomiast w przypadku innych zadań ich realizacja wymaga zaangażowania struktur wyższego rzędu, działających na rzecz tych podmiotów (np. państwa, całego społeczeństwa, wspólnoty samorządowej). Idea pomocniczości opiera się na założeniu, że - w miarę możliwości - należy przekazywać realizację zadań publicznych na rzecz tych podmiotów, których one bezpośrednio dotyczą, natomiast struktury wyższego rzędu nie powinny wyręczać ich w realizacji tych zadań, choć celowe może być wsparcie udzielane przez te struktury. Tym samym kryterium dyferencjacji podmiotów wykonujących zadania jest ich „bliskość do obywateli”, w interesie których (na rzecz których) zadania te są wykonywane. Z kolei jeżeli podmioty niższego rzędu nie są zdolne do wykonywania określonych zadań bądź też inne względy (np. efektywność) przemawiają za przekazaniem tych zadań na rzecz struktur wyższych - zadania te powinny być wykonywane przez te struktury.

Omawiana zasada znajduje zastosowanie w różnych układach odniesienia, pomiędzy różnymi strukturami i podmiotami (społeczeństwo-jednostka, państwo-jednostka, państwo-przedsiębiorca, państwo-samorząd, samorząd wyższego szczebla - samorząd niższego szczebla). W sferze prawa publicznego zasada pomocniczości wyznacza, w pierwszym rzędzie, postulowany podział zadań publicznych pomiędzy państwo a samorząd terytorialny, oraz - w ramach samego samorządu - pomiędzy poszczególne szczeble tego samorządu. W tym obszarze zasada pomocniczości nie odnosi się bezpośrednio do jednostek (ludzi), a do wspólnot tworzonych przez jednostki, z tego względu wyróżnia się wspólnotę większą (państwo albo jednostka samorządu terytorialnego wyższego szczebla) i wspólnotę mniejszą (jednostka samorządu terytorialnego albo odpowiednio jednostka samorządu terytorialnego niższego szczebla). 
Istotne znaczenie dla rekonstrukcji treści normatywnej zasady pomocniczości odgrywa orzecznictwo Trybunału Konstytucyjnego. Zdaniem sądu konstytucyjnego omawiana zasada, w najbardziej ogólnym rozumieniu, nakazuje powierzanie realizacji zadań publicznych „na poziom takich struktur, które pozostają najbliżej obywatela” (wyrok TK z 7 grudnia 2005 r., sygn. akt Kp 3/05), „państwo, rozdzielając $\mathrm{w}$ drodze ustaw konkretne zadania publiczne, musi wybierać optymalne podmioty, które je zrealizują. Zasada pomocniczości zakłada samodzielne wykonywanie zadań publicznych przez poszczególne wspólnoty w społeczeństwie” (wyrok TK z 7 marca 2012 r., sygn. akt K 3/10), „państwo nie powinno wykonywać zadań, które mogą być wykonywane w sposób bardziej efektywny przez mniejsze wspólnoty obywateli” (wyrok TK z 12 marca 2007 r., sygn. akt K 54/05), „[z]akłada ona [zasada pomocniczości - uwaga Z.G.] podejmowanie przez państwo aktywnych działań w sytuacji, w której jednostki bądź inne działające $\mathrm{w}$ ich imieniu podmioty, nie są $\mathrm{w}$ stanie samodzielnie zaspokoić swoich uzasadnionych potrzeb" (wyrok TK z 4 listopada 2015 r., sygn. akt K 1/14).

3. Artykuł 5 Konstytucji („Rzeczpospolita Polska strzeże niepodległości i nienaruszalności swojego terytorium, zapewnia wolności i prawa człowieka i obywatela oraz bezpieczeństwo obywateli, strzeże dziedzictwa narodowego oraz zapewnia ochronę środowiska, kierując się zasadą zrównoważonego rozwoju") wymienia najważniejsze wartości i cele, które powinny być realizowane w działalności organów władz publicznych. Ze względu na przedmiotowe zróżnicowanie obowiązków wymienionych $\mathrm{w}$ art. 5 Konstytucji, przepis ten może być traktowany jako wyrażający odrębne zasady konstytucyjne (obowiązek zapewnienia wolności i praw człowieka, obowiązek ochrony dziedzictwa narodowego, obowiązek zapewnienia ochrony środowiska w sposób urzeczywistniający zasadę zrównoważonego rozwoju). Do takiego ujęcia odwołał się również Wnioskodawca I, który wzorzec kontroli zawarty w art. 5 Konstytucji przywołał w zakresie, w jakim przepis ten wyraża zasadę zrównoważonego rozwoju w sferze ochrony środowiska (trzeba zaznaczyć, że Wnioskodawca I określa wprawdzie tę zasadę jako „zasadę zrównoważonego rozwoju”, ale zarazem wiąże ją z zawartym $\mathrm{w}$ art. 5 obowiązkiem państwa wyrażającym się w zapewnieniu ochrony środowiska). Powyższa okoliczność wyznacza niezbędny zakres analizy wzorca zawartego w art. 5 Konstytucji.

Przyjmuje się, że na gruncie art. 5 Konstytucji pojęcie „ochrona środowiska” obejmuje „każde działanie lub zaniechanie działań, które ma na celu zachowanie lub przywrócenie równowagi przyrodniczej" (J. Stelmasiak, Geneza prawnego pojęcia „środowisko" jako przedmiotu ochrony prawnej [w:] Państwo, prawo, myśl prawnicza. Prace dedykowane profesorowi Grzegorzowi Leopoldowi Seidlerowi $w$ dziewięćdziesiąta rocznice urodzin, red. A. Korobowicz, L. Leszczyński, A. Pieniążek, M. Stefaniuk, Lublin 2003, s. 273). Wskazanie, że zapewnienie ochrony środowiska spoczywa na Rzeczypospolitej oznacza, iż obowiązek ten wiąże wszystkie organy władzy publicznej. Istotnym komponentem obowiązku 
wynikającego z art. 5 Konstytucji jest nakaz kierowania się zasadą zrównoważonego rozwoju. Przyjmuje się, że wymaganie przestrzegania zasady zrównoważonego rozwoju oznacza, że wszędzie tam, gdzie miałoby dochodzić do ingerencji w „środowisko”, należy dbać nie tylko o to, aby ingerencja ta była jak najmniejsza (najmniej szkodliwa), lecz także o to, by osiągane korzyści społeczne były co najmniej proporcjonalne, społecznie adekwatne do strat, jakie się wówczas ponosi (zob. L. Garlicki, Komentarz do art. 5 [w:] Konstytucja Rzeczypospolitej Polskiej. Komentarz, t. I, red. L. Garlicki, M. Zubik, Warszawa 2016, s. 235).

Wyjaśniając treść zasady zrównoważonego rozwoju, sąd konstytucyjny wskazywał, że: „Ochrona środowiska jest jednym z elementów «bezpieczeństwa ekologicznego», ale zadania władz publicznych są szersze - obejmują też działania poprawiające aktualny stan środowiska i programujące jego dalszy rozwój. Podstawową metodą uzyskania tego celu jest - nakazane przez art. 5 Konstytucji kierowanie się zasadą zrównoważonego rozwoju [...]. W ramach zasady zrównoważonego rozwoju mieści się nie tylko ochrona przyrody czy kształtowanie ładu przestrzennego, ale także należyta troska o rozwój społeczny i cywilizacyjny, związany z koniecznością budowania stosownej infrastruktury, niezbędnej dla - uwzględniającego cywilizacyjne potrzeby - życia człowieka i poszczególnych wspólnot. Idea zrównoważonego rozwoju zawiera więc w sobie potrzebę uwzględnienia różnych wartości konstytucyjnych i stosownego ich wyważenia" (wyrok TK z 6 czerwca 2006 r., sygn. akt K 23/05; zob. także wyrok TK z 28 września 2015 r., sygn. akt K 20/14).

4. Zasada proporcjonalności stanowi jedną z zasad pochodnych wywodzonych z klauzuli demokratycznego państwa prawnego, statuowanej w art. 2 Konstytucji (por. np. wyrok TK z 25 listopada 2003 r., sygn. akt K 37/02). Zasada ta jest rozumiana - w najbardziej ogólny sposób - jako „zakaz arbitralnego traktowania jednostek oraz nadmiernej ingerencji państwa w stosunki społeczne” (W. Sokolewicz, M. Zubik, Komentarz do art. 2 [w:] Konstytucja Rzeczypospolitej Polskiej. Komentarz, t. I, red. L. Garlicki, M. Zubik, Warszawa 2016, s. 153-154).

Dla ustalenia treści zasady proporcjonalności wynikającej z art. 2 Konstytucji kluczowe znaczenie ma okoliczność, że na gruncie konstytucyjnym zasadę proporcjonalności wyraża w pierwszej kolejności art. 31 ust. 3 ustawy zasadniczej. Przepis ten został jednak zamieszczony w rozdziale II Konstytucji, regulującym konstytucyjne wolności i prawa przysługujące jednostkom. W konsekwencji art. 31 ust. 3 Konstytucji obejmuje wyłącznie sytuacje polegające na wprowadzeniu ograniczeń w sferze konstytucyjnych wolności i praw (tym samym omawiana zasada nie ma zastosowania w przypadku praw mających wyłącznie podstawę ustawową), przy czym chodzi tylko o prawa i wolności przysługujące jednostkom i podmiotom podobnym (stąd na naruszenie art. 31 ust. 3 Konstytucji nie mogą się powoływać np. organy samorządu terytorialnego). Wymienione ograniczenia (podmiotowe i przedmiotowe) nie dotyczą natomiast zasady proporcjonalności wywodzonej z art. 2 Konstytucji. 
Zróżnicowanie zakresu podmiotowego i przedmiotowego obowiązywania zasady proporcjonalności w ujęciu art. 2 i art. 31 ust. 3 Konstytucji jest podkreślane w orzecznictwie Trybunału Konstytucyjnego. Sąd konstytucyjny wskazywał, że zasada proporcjonalności wywodzona z art. 2 Konstytucji może „stanowić wzorzec kontroli w tych wypadkach, w których niemożliwe jest odwołanie się do art. 31 ust. 3 Konstytucji”. Z kolei „zasada proporcjonalności wynikająca z art. 2 Konstytucji pozwala na ocenę korzystania przez ustawodawcę ze swobody regulacyjnej w oderwaniu od naruszenia konkretnego prawa lub wolności konstytucyjnej. Dotyczy bowiem najczęściej ograniczenia praw lub wolności gwarantowanych jedynie na poziomie ustawowym albo też konstytucyjnych praw różnie rozumianych podmiotów publicznych czy też wreszcie oceny ograniczenia praw majątkowych wynikającego z nałożenia lub zwiększenia obowiązku podatkowego, do których to - wedle utrwalonej linii orzeczniczej TK - nie ma zastosowania art. 31 ust. 3 Konstytucji" (wyrok TK z 11 lutego 2014 r., sygn. akt P 24/12 oraz z 4 grudnia 2018 r., sygn. akt $P$ 12/17).

Precyzując treść zasady proporcjonalności na gruncie art. 2 Konstytucji przywołać należy następujące wypowiedzi sądu konstytucyjnego: „zarzut nieproporcjonalności uregulowania może być oparty wyłącznie na naruszeniu art. 2 Konstytucji jako «zarzut nierzetelnego, niezrozumiale intensywnego działania ustawodawcy, korzystającego ze swej swobody regulacyjnej»" (wyrok TK z 13 marca 2007 r., sygn. akt K 8/07); , "[w]ywiedziona z art. 2 Konstytucji zasada proporcjonalności szczególny nacisk kładzie na adekwatność celu legislacyjnego i środka użytego do jego osiągnięcia. To znaczy, że spośród możliwych (i zarazem legalnych) środków oddziaływania należałoby wybrać środki skuteczne dla osiągnięcia celów założonych, a zarazem najmniej uciążliwe dla podmiotów, wobec których mają być zastosowane, lub dolegliwe w stopniu nie większym niż jest to niezbędne dla osiągnięcia założonego celu" (wyrok TK z 16 lipca 2009 r., sygn. akt Kp 4/08).

Zdaniem Trybunału Konstytucyjnego przy ocenie dochowania przez prawodawcę zasady proporcjonalności wywodzonej z art. 2 Konstytucji zasadne jest odwołanie się do testu proporcjonalności wypracowanego na podstawie art. 31 ust. 3 Konstytucji - „Rozpatrując zgodność zakwestionowanej regulacji z zasadą proporcjonalności (z art. 2 Konstytucji) należy zbadać trzy istotne zagadnienia: 1) czy ta regulacja jest niezbędna dla ochrony i realizacji interesu publicznego, z którym jest związana, 2) czy jest efektywna, umożliwiając osiągnięcie zamierzonych celów, 3) czy jej efekty pozostają w odpowiedniej proporcji do ciężarów nakładanych na obywatela lub inny podmiot prawny" (wyrok TK z 9 lipca 2012 r., sygn. akt P 8/10).

5. Artykuł 64 Konstytucji statuuje prawo własności jako konstytucyjne prawo przysługujące jednostce. W kolejnych ustępach tego artykułu ustrojodawca proklamował prawo do własności, prawo do innych praw majątkowych oraz prawo do dziedziczenia (ust. 1), wprowadził równą ochronę prawną uprawnień właści- 
cielskich (ust. 2), jak również określił przesłanki, których spełnienie warunkuje dopuszczalność ograniczenia prawa własności (ust. 3).

Artykuł 64 ust. 1 Konstytucji przewiduje objęcie ochroną prawną wszystkich praw majątkowych przysługujących jednostce, do których zalicza się prawo własności, prawo dziedziczenia oraz inne prawa majątkowe. Ustrojodawca posłużył się otwartą formułą („inne prawa majątkowe”), która jednoznacznie świadczy o intencji objęcia konstytucyjną gwarancją możliwie szerokiego katalogu praw majątkowych (zob. wyrok TK z 3 października 2000 r., sygn. akt K 33/99). Naruszenie istoty prawa majątkowego chronionego przez art. 64 Konstytucji występuje wtedy, gdy wprowadzone ograniczenia dotyczą podstawowych uprawnień składających się na treść danego prawa i uniemożliwią realizację przez nie funkcji, którą ma ono pełnić w porządku prawnym (np. wyrok TK z 11 maja 2010 r., sygn. akt SK 50/08), lub w ogóle uniemożliwią korzystanie z tego prawa (np. wyrok TK z 25 maja 1999 r., sygn. akt SK 9/98).

Z nakazu ochrony własności oraz innych praw majątkowych statuowanego w art. 64 ust. 1 Konstytucji wynikają określone powinności dla ustawodawcy zwykłego. Zalicza się do nich obowiązek pozytywny stanowienia przepisów i procedur udzielających ochrony prawnej prawom majątkowym oraz obowiązek negatywny polegający na powstrzymywaniu się od wprowadzenia regulacji, które owe prawa mogłyby pozbawiać ochrony prawnej lub też ochronę tę ograniczać. Ochrona zapewniana majątkowym prawom podmiotowym musi być ponadto realna. Punktem odniesienia (kryterium weryfikacji tej cechy) musi być skuteczność realizacji określonego prawa podmiotowego w konkretnym otoczeniu systemowym, w którym ono funkcjonuje (np. wyrok TK z 3 kwietnia 2008 r., sygn. akt K 6/05). Sąd konstytucyjny wyraził również pogląd, że konstytucyjna ochrona praw majątkowych powinna polegać nie tylko na eliminowaniu działań faktycznych, prowadzących do uniemożliwienia uprawnionemu korzystania z przysługującego prawa, ale także na takim ukształtowaniu unormowań pozytywnych dotyczących treści danego prawa, które w znacznym stopniu ogranicza niebezpieczeństwo jednostronnego zniweczenia ekonomicznej istoty danego prawa, związanego z zachowaniem jego realnej wartości (np. wyrok TK z 3 października 2000 r., sygn. akt K 33/99).

Zasada równej ochrony prawa własności, wyrażona w art. 64 ust. 2 Konstytucji, stanowi pochodną konstytucyjnej zasady równości, wyrażonej w art. 32 Konstytucji (np. wyrok TK z 3 października 2000 r., sygn. akt K 33/99). Jednocześnie art. 64 ust. 2 Konstytucji dopełnia regulacje zawarte odpowiednio w art. 21 ust. 1 oraz w art. 64 ust. 1 Konstytucji (zob. wyrok TK z 28 października 2003 r., sygn. akt P 3/03). Omawiana zasada nabiera istotnego znaczenia w perspektywie regulacji prawnych przyjmowanych przed 1989 r., które przewidywały szczególne instrumenty ochrony własności społecznej (państwowej), niedostępne dla podmiotów prywatnych. Ten aspekt wyraźnie akcentował Trybunał Konstytucyjny, wskazując na zakaz wprowadzania preferencji w zakresie ochrony praw majątko- 
wych dla podmiotów państwowych (np. wyrok TK z 24 lutego 2009 r., sygn. akt SK 34/07).

Z kolei w ust. 3 art. 64 Konstytucji sprecyzowano przesłanki ograniczenia prawa własności („Własność może być ograniczona tylko w drodze ustawy i tylko w zakresie, w jakim nie narusza ona istoty prawa własności”). Z cytowanego przepisu wyprowadzany jest bezwzględny zakaz naruszania istoty prawa własności, co oznacza, że ustawodawca nie może przyjmować regulacji prawnych, które uniemożliwiałyby korzystanie z prawa własności (zob. wyrok TK z 21 marca 2000 r., sygn. akt K 14/99).

Obowiązek zapewnienia równej ochrony praw majątkowych nie ma charakteru bezwzględnego. Prawodawca może wprowadzić w tym względzie zróżnicowanie co do zakresu bądź środków ochrony, o ile ma to racjonalne uzasadnienie, jest proporcjonalne oraz znajduje oparcie w innych konstytucyjnie chronionych wartościach (zob. wyrok TK z 21 grudnia 2005 r., sygn. akt SK 10/05).

\section{- 3. Ocena konstytucyjności}

3.1. Lokalizacja elektrowni wiatrowej w określonym miejscu, jak i praca tej elektrowni wywierają różnego rodzaju wpływ na otoczenie. Po pierwsze, praca elektrowni wiatrowej związana jest z emisją hałasu. Chodzi przy tym nie tylko o dźwięk o częstotliwościach odbieranych przez ludzkie ucho, ale także infradźwięki, które - choć niesłyszalne dla ludzkiego ucha - to mogą być jednak odbierane przez człowieka i wywoływać poczucie dyskomfortu. Dla ludzi zamieszkujących w bezpośrednim sąsiedztwie elektrowni wiatrowej istotne jest przy tym, że hałas - w różnym nasileniu - jest generowany przez cały czas, kiedy wirnik elektrowni wiatrowej znajduje się w ruchu. Z kolei oddziaływanie wizualne elektrowni wiatrowej związane jest przede wszystkim z gabarytami tych obiektów. Ich wysokość przekraczać może nawet $200 \mathrm{~m}$. Z tego względu elektrownie wiatrowe stają się elementem w szczególny sposób oddziałującym na lokalny krajobraz i walory estetyczne przestrzeni. Przy tym obiekty te sytuowane są głównie na terenach niezabudowanych, stając się jedyną dominantą przestrzenną. Obiekty tego rodzaju mają przy tym zdecydowanie industrialny charakter, stąd też mogą być postrzegane jako zaburzające harmonię i estetykę krajobrazu w przypadku, jeżeli sąsiadują one z obiektami zabytkowymi czy też kompleksami przyrodniczymi zasługującymi na szczególną ochronę. W sferze oddziaływania wizualnego mieści się także efekt migotania wywoływany przez ruch obracającego się wokół własnej osi wirnika.

Innego rodzaju oddziaływanie elektrowni wiatrowej na otocznie związane jest z ruchem, który wykonuje jej wirnik. W przypadku uszkodzenia wirnika, polegającego przykładowo na oberwaniu się śmigła bądź jego fragmentów, upadek tych elementów stanowi niebezpieczeństwo dla bezpośredniego otoczenia. Przy czym różnie określa się odległość, w jakiej od elektrowni wiatrowej mogą upaść takie uszkodzone elementy, stanowiąc zagrożenia dla znajdujących się tam 
ludzi oraz zabudowań. Według danych przedstawionych przez Wnioskodawcę I, który oparł się na wynikach badań przeprowadzonych w innych państwach (w szczególności w Niemczech), elementy uszkodzonego wirnika czy też gondoli elektrowni, nawet przy bardzo silnym wierze, nie mogą upaść dalej niż na odległość stanowiącą dwukrotność bądź trzykrotność wysokości elektrowni wiatrowej. Z kolei z opracowań naukowych, na których oparli się autorzy projektu ustawy o inwestycjach, wynika, że odległość ta jest znacznie większa. Uznano mianowicie, że strefa zagrożenia odłamkami stanowiącymi uszkodzone części wirnika bądź innych mechanizmów obejmuje, przy sprzyjających warunkach atmosferycznych, odległość stanowiącą nawet dziesięciokrotność wysokości elektrowni (druk sejmowy nr 315/VIII kad., uzasadnienie, s. 6). Innego rodzaju oddziaływaniem związanym $\mathrm{z}$ ruchem wirnika może być ponadto - w warunkach zimowych - odrywanie się od powierzchni śmigieł bryłek lodu. Także w tym aspekcie rozbieżne są opinie co do odległości, w jakiej takie bryłki mogą upaść.

Przytoczone okoliczności jednoznacznie wskazują, że fakt lokalizacji elektrowni wiatrowej $\mathrm{w}$ danym miejscu oddziałuje na otoczenie, jak również na osoby zamieszkałe w bezpośredniej odległości od elektrowni. Przy czym wpływ ten ma charakter wieloaspektowy i - co do niektórych elementów - zmienny. I tak, nasilenie hałasu generowanego przez wirnik zależy od prędkości, z jaką wirnik się obraca, ta zaś zależy od siły wiatru. Zarazem nasilenie dźwięku jest wprost zależne od wielkości wirnika. Innym elementem decydującym o immisjach elektrowni $\mathrm{w}$ aspekcie generowanego hałasu jest ukształtowanie terenu oraz siła i kierunek wiatrów dominujących w danej lokalizacji. Ponadto oddziaływanie elektrowni obejmuje elementy, które mogą być w zindywidualizowany sposób odbierane przez poszczególne osoby. I tak u jednej osoby fakt przebywania w środowisku, w którym występują infradźwięki, może być odbierany w sposób całkowicie obojętny, podczas gdy u innej osoby mogą wynikać z tego określone dolegliwości (np. chroniczne bóle głowy). Stąd też w znacznej części przypadków fakt lokalizacji elektrowni wiatrowej może być odbierany przez okolicznych mieszkańców jako stan niekorzystny. Na tym tle istotne pozostaje - retoryczne, jak się wydaje - pytanie, czy planując inwestycję na określonym obszarze polegającą na budowie elektrowni wiatrowej, to inwestor tej elektrowni powinien dostosować się do istniejących warunków lokalnych, czy też to mieszkańcy mają znosić immisje związane z funkcjonowaniem wybudowanej później elektrowni wiatrowej.

3.2. Oddziaływanie elektrowni wiatrowej na otoczenie, jak również na osoby zamieszkałe w bezpośrednim sąsiedztwie, musi zostać uwzględnione przez organy państwa. Dlatego też wydając zgodę na lokalizację elektrowni wiatrowej, organy te powinny brać pod uwagę wpływ tego typu obiektu na środowisko oraz na osoby zamieszkałe w sąsiedztwie. Przy czym wydanie konkretnej decyzji lokalizacyjnej powinno być oparte na założeniu, że funkcjonowanie elektrowni nie może w nadmiernym stopniu wpływać negatywnie na otoczenie, jak i zamieszkałe tam osoby. 
Zasadniczo wyróżnić można dwa modele określenia oddziaływania elektrowni wiatrowej na otoczenie. Pierwszy oparty jest na ocenie przeprowadzanej w odniesieniu do konkretnej lokalizacji i parametrów elektrowni. Podstawowy instrument $\mathrm{w}$ tym względzie stanowi decyzja o środowiskowych uwarunkowaniach zgody na realizację przedsięwzięcia, określająca wpływ elektrowni wiatrowej na środowisko. $\mathrm{Z}$ kolei $\mathrm{w}$ sferze planowania i zagospodarowania przestrzennego lokalizacja elektrowni wiatrowej musi być zgodna z postanowieniami miejscowego planu obowiązującego dla danego terytorium. W razie braku takiego planu wpływ planowanej elektrowni na otoczenie (krajobraz) podlega ocenie w toku wydawania decyzji o warunkach zabudowy. Drugi model polega na przyjęciu sztywnych parametrów wyznaczających sferę oddziaływania elektrowni wiatrowej na otoczenie (środowisko). Realizując ten model, ustawodawca określa limity odległościowe, ustalające minimalną odległość elektrowni wiatrowej od obiektów, na które elektrownia oddziałuje, w tym w szczególności od zabudowy mieszkaniowej. Limity te mogą być zwiększone po przeprowadzeniu indywidualnej oceny oddziaływania konkretnego obiektu na środowisko i na otoczenie. Wybór jednego z tych modeli pozostaje w sferze uznania prawodawcy. Zarazem jednak ustawodawca, decydując się na wprowadzenie danego modelu, powinien dokonać oceny zalet i wad każdego $\mathrm{z}$ nich.

Przed wejściem w życie ustawy o inwestycjach w Polsce obowiązywał pierwszy z wyróżnionych modeli. Nie było żadnych przepisów o charakterze powszechnie obowiązującym, które określałyby zasady lokalizacji elektrowni wiatrowych. Ocena oddziaływania elektrowni wiatrowej dokonywana była indywidualnie w odniesieniu do konkretnej inwestycji, zaś podstawowy instrument w tym względzie stanowiła decyzja o środowiskowych uwarunkowaniach przedsięwzięcia. Natomiast w wymiarze prawa budowlanego, wobec niewielkiego pokrycia obszaru kraju miejscowymi planami zagospodarowania, wyrażenie zgody na lokalizację w danym miejscu elektrowni wiatrowej odznaczającej się określonymi gabarytami następowało na podstawie decyzji o warunkach zabudowy. Zmiana opisanego modelu ustalania zasad lokalizacji elektrowni wiatrowych nastąpiła wraz z wejściem w życie ustawy o inwestycjach. Ustawa ta wprowadziła bezwzględne limity odległościowe dotyczące lokowania elektrowni wiatrowych względem istniejącej wcześniej na danym terenie zabudowy mieszkaniowej.

W ocenie ustawodawcy interes okolicznych mieszkańców nie był - na gruncie dotychczasowych regulacji, a więc przed wejściem w życie ustawy o inwestycjach - chroniony w należyty sposób. Elektrownie wiatrowe były lokowane od istniejącej zabudowy mieszkaniowej w odległości, które nie zapewniały należytego zabezpieczenia przed immisjami wynikającymi z pracy elektrowni. Stąd też ustawodawca uznał, że dotychczasowy system ochrony przed negatywnym oddziaływaniem na otoczenie i zamieszkałe tam osoby był nie tylko nieefektywny, ale wręcz miał charakter dysfunkcjonalny (zob. druk sejmowy nr 315/VIII kad., uzasadnienie, s. 1 i n.). 
3.3. Nie budzi wątpliwości, że ustalenie limitów odległości może być postrzegane jako ingerencja w sferę prawa własności. Każda bowiem regulacja, która określa zasady sytuowania obiektów budowlanych (a więc także np. przepisy rozporządzenia Ministra Infrastruktury z dnia 12 kwietnia 2002 r. w sprawie warunków technicznych, jakim powinny odpowiadać budynki i ich usytuowanie, t.j. Dz. U. 2015, poz. 1422, ze zm.) stanowią wkroczenie w sferę uprawnień właścicielskich. Stąd też ocena kwestionowanych przez obu wnioskodawców przepisów powinna się koncentrować na odpowiedzi na pytanie, czy w świetle zasad i wartości konstytucyjnych wynikające $\mathrm{z}$ nich ograniczenia są dopuszczalne. W konsekwencji zgodzić się należy z wnioskodawcami, że adekwatny wzorzec kontroli w tym wypadku stanowi zasada proporcjonalności, zarówno w ujęciu wynikającym $z$ art. 31 ust. 3 Konstytucji (i w takim kształcie wyznacza ona konstytucyjne ramy ograniczeń w sferze prawa własności), jak i zasada proporcjonalności wywodzona $\mathrm{z}$ art. 2 Konstytucji.

Wprowadzając ograniczenia dotyczące lokalizacji elektrowni wiatrowych prawodawca zobowiązany jest uwzględnić interesy każdej ze stron, na które regulacje te oddziałują. Ustawodawca przyjął założenie, zgodnie z którym w stanie prawnym przed wejściem w życie ustawy o inwestycjach interes osób zamieszkałych w bezpośrednim sąsiedztwie elektrowni wiatrowych, jak również osób zamieszkałych na obszarach, dla których tego typu inwestycja jest planowana, nie był chroniony w należytym stopniu. Stąd też zdecydowano się na ustalenie na poziomie ustawowym ścisłych kryteriów odległościowych, których spełnienie warunkuje lokalizację elektrowni wiatrowej. Wyznaczenie konkretnych limitów odległościowych jest objęte - w istotnym stopniu - uznaniem przysługującym ustawodawcy. Analogiczny charakter mają inne limity odległościowe wyznaczone w prawie budowlanym (np. obowiązek zachowania odpowiedniej odległości od granicy działki przy sytuowaniu budynku na działce mieszkaniowej, tj. odległości nie mniejszej niż $4 \mathrm{~m}$ w przypadku budynku zwróconego ścianą z otworami okiennymi lub drzwiowymi w stronę tej granicy oraz odległości nie mniejszej niż $3 \mathrm{~m}$ w przypadku budynku zwróconego ścianą bez otworów okiennych lub drzwiowych w stronę tej granicy).

Na gruncie art. 31 ust. 3, jak również art. 2 Konstytucji ocena zgodności kwestionowanych przepisów oparta jest na tzw. teście proporcjonalności. Na tym tle Sejm stwierdza, że kryterium $10 \mathrm{H}$ realizuje cel przypisany powyższej regulacji przez ustawodawcę, a więc zapewnia ochronę przed potencjalnie niebezpiecznym oddziaływaniem elektrowni w razie katastrof czy awarii technicznych, ale także zapewnia ochronę okolicznych mieszkańców przed immisjami wynikającymi z pracy elektrowni wiatrowej (pierwsze pytanie testu proporcjonalności). Wprowadzenie limitu odległościowego niewątpliwie służy także realizacji wartości konstytucyjnych. Są nimi ochrona interesów mieszkańców (ochrona przysługującego im prawa własności, a także takich wartości jak zdrowie, prawo do odpoczynku itp.), jak również ochrona walorów krajobrazowych przestrzeni. Ta 
ostatnia wartość znajduje zakotwiczenie konstytucyjne, choćby na gruncie art. 5 ustawy zasadniczej (drugie pytanie testu proporcjonalności). Wreszcie wprowadzona regulacja ingerująca $\mathrm{w}$ sferę prawa własności jest dopuszczalna tylko wówczas, gdy wynikające stąd ograniczenia nie mają nadmiernego charakteru. Wprowadzone ograniczenia wynikające $\mathrm{z}$ limitu $10 \mathrm{H}$ mogą być wprawdzie postrzegane jako rygorystyczne z punktu widzenia podmiotów wykonujących działalność gospodarczą w sferze energetyki wiatrowej, ale mieszczą się one w zakresie przysługującej ustawodawcy swobody regulacyjnej i nie stanowią nadmiernej ingerencji. Pozostają one jednocześnie w odpowiedniej proporcji do znaczenia dóbr, które chronić ma zakaz wyrażający się w kryterium $10 \mathrm{H}$, a więc ochrony konstytucyjnych interesów mieszkańców. Innymi słowy, kwestionowane przez wnioskodawców regulacje w sposób adekwatny dokonują wyważenia interesów inwestorów prowadzących działalność w zakresie elektrowni wiatrowych oraz osób narażonych na immisje wynikające z działalności tych obiektów (trzecie pytanie testu proporcjonalności).

Należy też zauważyć, że nie można zgodzić się ze stanowiskiem wyrażonym przez Wnioskodawcę I, że grono osób narażanych na negatywne oddziaływanie elektrowni wiatrowych pozostaje - w skali kraju - nieliczne. Zdaniem Wnioskodawcy I ma to przesądzać o tym, że interes tej grupy nie zasługuje na ochronę, a tym bardziej nie może być uznany za mieszczący się w kategorii interesu publicznego. Jeżeli przyjąć powyższą logikę opartą na kryteriach ilościowych, to należałoby w konsekwencji zauważyć, że znacząco mniej liczne pozostaje grono podmiotów prowadzących inwestycje w zakresie elektrowni wiatrowych, ale także właścicieli dzierżawiących swoje nieruchomości pod tego typu działalność. Oznaczałoby to zatem, że interes ten, jako przysługujący znikomej grupie podmiotów, nie zasługuje na ochronę, a co najmniej stopień tej ochrony nie powinien być taki sam, jak interesu okolicznych mieszkańców. Powyższe rozumowanie nie zasługuje na uwzględnienie.

Przyjęte w ustawie o inwestycjach limity odległościowe są bardziej rygorystyczne niż przyjmowane w tym względzie w niektórych innych państwach, na co powoływali się obaj wnioskodawcy. We wniosku II uznano, że najbardziej pożądanym rozwiązaniem jest regulacja obowiązująca w Danii, gdzie przyjęto jako limit odległościowy kryterium $4 \mathrm{H}$. Nie oznacza to jednak automatycznie, że polskie regulacje w tym względzie są niewłaściwe, w szczególności zaś argument ten w żaden sposób nie przesądza ewentualnie kwestii ich konstytucyjności.

W dalszej kolejności trzeba zauważyć, że zdaniem wnioskodawców ograniczenie możliwości lokowania nowych elektrowni wiatrowych wynika $\mathrm{z}$ kumulacji dwóch czynników. Po pierwsze, z samej wielkości przyjętego kryterium 10H, po drugie $-\mathrm{z}$ rozproszonego charakteru zabudowy występującej w Polsce. Ten ostatni aspekt powoduje, że na terytorium Polski nieliczne są obszary (wedle różnych szacunków, na które powołują się wnioskodawcy, jest to od $0,5 \%$ do $2,5 \%$ powierzchni kraju), dla których spełnione jest kryterium $10 \mathrm{H}$. Odnosząc 
się do powyższego zarzutu, warto zauważyć, że istniejące obiektywnie uwarunkowania (rozproszona zabudowa na terytorium kraju) nie stanowi argumentu, który usprawiedliwiałby zmniejszenie ochrony mieszkańców terenów sąsiadujących bezpośrednio z elektrownią wiatrową. Wnioskodawcy przyjmują bowiem koncepcję, że limity odległościowe powinny być dostosowane do struktury zabudowy w Polsce. Innymi słowy, jeżeli zabudowa mieszkaniowa jest rozproszona, to odpowiednio powinno to skutkować zmniejszeniem limitów odległościowych, nawet jeśli skutkowałoby to brakiem zapewnienia należytej ochrony okolicznym mieszkańcom. Nie można zgodzić się z takim stanowiskiem.

Trzeba również odnieść się do argumentu wskazanego przez wnioskodawców, zgodnie z którym przyjęte limity odległościowe de facto skutkują wprowadzeniem bezwzględnego zakazu lokalizacji elektrowni wiatrowych na zdecydowanej większości terytorium państwa. Warto jednak zauważyć, że istniejąca na danym obszarze zabudowa nie jest elementem stałym, a, co więcej, inwestor nie jest pozbawiony możliwości wpływania na obecność zabudowy mieszkaniowej na obszarze, na którym planuje lokalizację elektrowni wiatrowej. Jeżeli zatem z planowaną lokalizacją elektrowni wiatrowej kolidują jeden bądź dwa budynki mieszkalne (a przyjmując fakt rozproszonej zabudowy w Polsce, nie jest to sytuacja rzadka), inwestor może wykupić tę nieruchomość, a następnie rozebrać istniejący tam budynek mieszkalny czy choćby zmienić jego funkcję użytkową. Biorąc pod uwagę ogólny koszt budowy elektrowni wiatrowej, koszty ewentualnego wykupu kolidujących nieruchomości mogą stanowić niewielki procent ogólnych kosztów budowy elektrowni.

Uwzględniając powyższą argumentację, trzeba wyrazić stanowisko, że zarzuty niezgodności przepisów wprowadzających kryterium $10 \mathrm{H}$ z zasadą proporcjonalności wywodzoną z art. 2 Konstytucji, a także z art. 31 ust. 3 i art. 64 Konstytucji nie zasługują na uwzględnienie.

3.4. Zdaniem Wnioskodawcy I kryterium $10 \mathrm{H}$ prowadzi także do naruszenia zasady zrównoważonego rozwoju w sferze ochrony środowiska. Argument ten związany jest - jak się wydaje - z wpływem, jaki wywiera produkcja energii elektrycznej z poszczególnych źródeł (ze spalania paliw kopalnych, z energetyki odnawialnej itd.) na stan środowiska. Chodzi zatem o sytuację, w której zahamowanie rozwoju energetyki wiatrowej w Polsce w następstwie wprowadzenia kryterium $10 \mathrm{H}$ powodować będzie utrzymanie obecnego udziału konwencjonalnych źródeł w bilansie energetycznym. To zaś będzie miało negatywny wpływ na stan środowiska, w szczególności uwzględniając udział węgla jako źródła produkcji energii elektrycznej i wynikające stąd skutki dla środowiska.

Wnioskodawca I nie przedstawił jednak danych, które obrazowałyby potencjalne negatywne skutki, w tym w szczególności wyrażające się w emisji $\mathrm{CO}_{2}$ do atmosfery $\mathrm{w}$ następstwie spalania paliw kopalnych przeznaczonych do produkcji energii elektrycznej. Ponadto pominięto okoliczność, że energia z elektrowni wiatrowych jest w rozrachunku ekonomicznym energią droższą od pozyskiwa- 
nej ze źródeł konwencjonalnych i dlatego wymaga odpowiednich zachęt (certyfikaty) ze strony państwa, co stanowi wyraz wsparcia dla produkcji energii z tego źródła przez państwo.

Dlatego też należy przyjąć, że zarzut naruszenia zasady zrównoważonego rozwoju nie może być uznany za należycie uzasadniony przez Wnioskodawcę I, a tym samym nie zasługuje na uwzględnienie.

Trzeba też podnieść generalną wątpliwość dotyczącą powołania jako wzorca kontroli art. 5 Konstytucji z uwagi na nadawany temu przepisowi charakter normy programowej. Jako norma programowa art. 5 Konstytucji wyznacza jedynie określony kierunek działania władz publicznych, natomiast zawarte w nim wymogi „nie rodzą więc po stronie jednostek bądź też bardziej czy mniej sformalizowanych grup społecznych egzekwowalnych prawnie roszczeń o działania władz na tyle skuteczne, aby przynosily zapowiadane przez ten przepis rezultaty" (P. Sarnecki, Komentarz do art. 5 [w:] Konstytucja Rzeczypospolitej Polskiej. Komentarz, t. I, red. L. Garlicki i M. Zubik, Warszawa 2016, s. 231).

3.5. Jako wzorzec kontroli obaj wnioskodawcy powołali również zasadę wolności działalności gospodarczej (art. 20 i art. 22 Konstytucji). Wprowadzenie limitów odległościowych przekłada się bowiem na zmniejszenie liczby potencjalnych lokalizacji elektrowni wiatrowych, to zaś skutkować ma ograniczeniem działalności gospodarczej w tej sferze.

Odnosząc się do powyższego zarzutu, łatwo zauważyć, że limit odległościowy wynikający z ustawy o inwestycjach dotyczy lokalizacji elektrowni wiatrowych jako obiektów budowlanych. Ograniczenia te obowiązują niezależnie od tego, czy budowa elektrowni wiatrowej jest realizowana $\mathrm{w}$ ramach prowadzonej działalności gospodarczej, czy poza nią. Oczywiście sytuacja, w której osoby fizyczne planowałyby budowę elektrowni wiatrowej o znacznych gabarytach na własne potrzeby, bez związku z prowadzoną działalnością gospodarczą, stanowi raczej sytuację hipotetyczną. Nie budzi jednak wątpliwości, że taka inwestycja - prowadzona przez osobę fizyczną - podlega limitom odległościowym wynikającym z kryterium $10 \mathrm{H}$. Limity te bowiem, co należy jeszcze raz podkreślić, dotyczą działania polegającego na lokalizacji w przestrzeni obiektu budowalnego, jakim jest elektrownia wiatrowa, nie są natomiast związane $\mathrm{z}$ faktem prowadzenia działalności gospodarczej w określonej sferze. Przy czym ograniczenia te mają charakter faktyczny i wynikają z określonego rozmieszczenia zabudowy mieszkaniowej na planowanym obszarze oddziaływania elektrowni wiatrowej. Tym samym na obszarze, na którym nie znajduje się zabudowa mieszkaniowa kolidująca $\mathrm{z}$ planowaną elektrownią wiatrową, realizacja tej inwestycji nie podlega żadnym ograniczeniom. Aktualna pozostaje w tej mierze argumentacja powołana w pkt III.3.2 stanowiska. Tym samym zasada wolności działalności gospodarczej (art. 20 Konstytucji), a także przepis określający dopuszczalne ograniczenia w obrębie tej zasady (art. 22 Konstytucji) nie mogą być uznane za adekwatne wzorce kontroli w kontekście zarzutu dotyczącego wprowadzenia kryterium $10 \mathrm{H}$. 
Powołana wyżej argumentacja przesądza także o braku zasadności zarzutu dotyczącego naruszenia zasady równości. Zarówno właściciele nieruchomości, na których planowana jest lokalizacja elektrowni wiatrowych, jak i przedsiębiorcy prowadzący działalność $\mathrm{w}$ tym obszarze traktowani są $\mathrm{w}$ ten sam sposób (tak samo). Do każdego z tych podmiotów stanowiących $\mathrm{w}$ analizowanym kontekście grupę podmiotów podobnych (grupę podmiotów odznaczających się wspólną cechą relewantną) w tym samym stopniu odnosi się kryterium $10 \mathrm{H}$. O zróżnicowaniu sytuacji tych podmiotów można mówić wyłącznie w wymiarze faktycznym. Poszczególne nieruchomości (a więc także i planowane na nich elektrownie wiatrowe) znajdują się bowiem w różnym oddaleniu od istniejącej zabudowy mieszkaniowej. Powyższa okoliczność nie ma jednak charakteru zróżnicowania prawnego. $Z$ tego względu stanowisko wnioskodawców o naruszeniu zasady równości (art. 32 ust. 1 Konstytucji) nie znajduje uzasadnienia.

3.6. Wreszcie wzorcem kontroli wskazanym przez Wnioskodawcę II jest zasada pomocniczości. Zasada ta wyznacza relacje między jednostką a państwem (władzą publiczną), a także między strukturami niższego rzędu i strukturami wyższego rzędu. Nie można dostrzec płaszczyzny, w której limity odległościowe wyrażające się w kryterium $10 \mathrm{H}$ mogłyby być uznane za naruszające zasadę pomocniczości w tym aspekcie, w jakim odnosi się ona do obywateli (a więc właścicieli nieruchomości, na których ma zostać zbudowana elektrownia wiatrowa bądź nieruchomości, na których elektrownia taka już działa) bądź przedsiębiorców. Łatwo stwierdzić natomiast, że wprowadzenie limitu odległościowego może być postrzegane jako skutkujące ograniczeniem zasady samodzielności gminy. Analiza konstytucyjności w tym zakresie została przedstawiona w pkt V stanowiska.

3.7. Mając na względzie powyższe, należy przyjąć, że art. 4 ust. 1, art. 6 i art. 7 ustawy:

- są zgodne z zasadą proporcjonalności wywodzoną z art. 2, zasadą zrównoważonego rozwoju wywodzoną $\mathrm{z}$ art. 5 oraz $\mathrm{z}$ art. 31 ust. 3, art. 32 ust. 1-2 i art. 64 ust. 1-3 Konstytucji,

- nie są niezgodne $z$ art. 20 i art. 22 Konstytucji.

\section{Ingerencja w sferę samodzielności samorządu terytorialnego}

\section{- 1. Zarzuty Wnioskodawcy I}

Wątpliwości pod adresem art. 4 ust. 1, art. 6 pkt 1-3 oraz art. 15 ust. 8-9 ustawy o inwestycjach dotyczą także obowiązku uwzględnienia kryterium odległościowego przez organy gminy przy sporządzaniu (zmianie) studium uwarunkowań i kierunków zagospodarowania przestrzennego gminy oraz przy sporządzaniu (zmianie) planu miejscowego, a przez organy gminy obowiązane są stosować te kryterium przy wydawaniu decyzji o warunkach zabudowy. Zdaniem Wnioskodawcy I ustawodawca narzucił w ten sposób organom gminy wiążące zasady ustalania przeznaczenia terenu oraz sposób jego zagospodarowania, czym na- 
ruszył zasadę samodzielności samorządu terytorialnego. Wprowadzenie ustawą ograniczenia $\mathrm{w}$ zakresie lokalizacji i budowy elektrowni wiatrowej na terenie gminy stanowi nadmierną ingerencję w sferę samodzielności gmin.

Rozwijając powyższe zarzuty, Wnioskodawca I wskazał, że kwestionowana regulacja ograniczyła władztwo planistyczne gmin. Zostały one pozbawione swobody kształtowania polityki przestrzennej wskutek ustalenia arbitralnego kryterium $10 \mathrm{H}$, wiążącego organy architektoniczne przy sporządzaniu (zmianie) studium oraz sporządzaniu (zmianie) planu miejscowego, a także przy wydawaniu decyzji o warunkach zabudowy. Ograniczenie odległościowe stanowi nieadekwatny środek zabezpieczenia społeczeństwa i środowiska przed ewentualnymi negatywnymi skutkami funkcjonowania elektrowni wiatrowych. Konieczność uwzględnienia przez gminy kryterium $10 \mathrm{H}$ dotyczy również tych sytuacji, gdy biorąc pod uwagę konkretną lokalizację - jego zastosowanie jest całkowicie nieuzasadnione. Dotyczy to w szczególności sytuacji, gdy istnieją odpowiednie warunki środowiskowo-techniczne sprzyjające funkcjonowaniu elektrowni wiatrowej, a jednocześnie lokalizacja elektrowni bez uwzględnienia kryterium $10 \mathrm{H}$ nie będzie zagrażać wartościom chronionym przez ustawodawcę. Powyższe kryterium jest nieelastyczne i nadmiernie ogranicza swobodę lokalizacji elektrowni wiatrowych, która i tak jest ograniczona pozostałymi przepisami (np. dotyczącymi poziomów hałasu) oraz uwarunkowaniami środowiskowo-technicznymi. Stanowi ono nieproporcjonalną ingerencję ustawodawcy w ukształtowany stan prawny i jest nieadekwatnym środkiem do osiągnięcia założonych celów, w czym Wnioskodawca I upatruje naruszenia art. 2 Konstytucji.

$\mathrm{Na}$ tle powyższych zarzutów Wnioskodawca I wniósł o stwierdzenie niezgodności art. 4 ust. 1, art. 6 pkt 1-3 oraz art. 15 ust. 8-9 ustawy o inwestycjach z art. 16 ust. 2 i art. 165 ust. 1 i 2 Konstytucji.

\section{Wzorce kontroli}

Wskazane wzorce kontroli Konstytucji mają następujące brzmienie:

- „Samorząd terytorialny uczestniczy w sprawowaniu władzy publicznej. Przysługującą mu w ramach ustaw istotną część zadań publicznych samorząd wykonuje w imieniu własnym i na własną odpowiedzialność” (art. 16 ust. 2).

- „Jednostki samorządu terytorialnego mają osobowość prawną. Przysługują im prawo własności i inne prawa majątkowe" (art. 165 ust. 1).

- „Samodzielność jednostek samorządu terytorialnego podlega ochronie sądowej" (art. 165 ust. 2).

$\mathrm{Z}$ uzasadnienia powołanego przez Wnioskodawcę I wynika, że art. 16 ust. 2 i art. 165 ust. 1-2 Konstytucji przywołano w charakterze wzorca kontroli w zakresie, w jakim przepisy te stanowią źródło konstytucyjnej zasady samodzielności samorządu terytorialnego. Okoliczność ta wyznacza zakres niezbędnej analizy wzorca kontroli. 
Ustrojodawca nie zdefiniował pojęcia samodzielności samorządu terytorialnego, choć posłużono się nim wprost w przepisach ustawy zasadniczej (art. 165 ust. 2 Konstytucji). W najbardziej zwięzłym ujęciu samodzielność samorządu terytorialnego należy traktować jako stan, w którym samorząd ten pozostaje podmiotem odrębnym w stosunku do innych organów władzy publicznej w sferze realizacji zadań publicznych, wykonującym przypisane zadania we własnym imieniu i interesie. Ramy odrębności przysługującej samorządowi, w granicach wyznaczonych przez Konstytucję, określa ustawodawca.

Warunkiem koniecznym dla realizacji zasady samodzielności jest wprowadzenie rozwiązań instytucjonalnych, zapewniających odrębność samorządu w wymiarze organizacyjnym, personalnym, majątkowym i kompetencyjnym. Atrybutami zapewniającymi samodzielność samorządowi terytorialnemu w tych sferach są m.in.: 1) wyposażenie jednostek samorządu w osobowość prawną (art. 165 ust. 1 Konstytucji); 2) wyposażenie jednostek samorządu w majątek (art. 165 ust. 1 Konstytucji); 3) wybór organów jednostek samorządu przez członków danej wspólnoty samorządowej (art. 169 Konstytucji); 4) przyznanie jednostkom samorządu odrębności finansowej oraz zapewnienie samorządowi odpowiednich źródeł dochodów (art. 167 Konstytucji). Ponadto samodzielność samorządu terytorialnego podlega ochronie sądowej, co wyraża się m.in. w przyznaniu jednostkom samorządu uprawnienia do inicjowania postępowania sądowego w przypadku ingerencji w sferę objętą samodzielnością (art. 165 ust. 2 Konstytucji).

W świetle orzecznictwa sądu konstytucyjnego zasada samodzielności stanowi podstawowy element konstrukcji ustroju samorządu terytorialnego (zob. wyrok TK z 16 marca 1999 r., sygn. akt K 35/98). Trybunał ujmuje tę samodzielność jako wymóg zapewnienia jednostkom samorządu szerokiego zakresu swobodnego decydowania o sprawach lokalnych w celu zaspokojenia potrzeb mieszkańców swojego terytorium (np. wyrok TK z 24 marca 1998 r., sygn. akt K 40/97), a także jako „niezależność od innych struktur i podmiotów władzy publicznej, a w szczególności od organów administracji rządowej" (orzeczenie TK z 23 października 1996 r., sygn. akt K 1/96). Trybunał często odwoływał się również do formuły, zgodnie z którą samodzielność samorządu oznacza stan, w którym „jednostki samorządu terytorialnego, wykonując zadania publiczne, uczestniczą w zakresie określonym przez ustawodawcę w sprawowaniu władzy w granicach przyznanej im przez prawo i prawem chronionej samodzielności” (wyrok TK z 24 listopada 1998 r., sygn. akt K 22/98). Trybunał w swoim orzecznictwie posługiwał się ponadto zakresową definicją zasady samodzielności samorządu terytorialnego, wymieniając cechy składające się na pojęcie samodzielności - „zasada samodzielności [...] oznacza w szczególności, że: 1) jednostki samorządu terytorialnego mają określony zakres zadań własnych związanych z zaspokajaniem potrzeb mieszkańców oraz zadań zleconych określonych przez ustawy; 2) jednostki samorządu terytorialnego samodzielnie realizują swoje zadania, wyraża- 
jąc wolę mieszkańców; 3) ingerencja organów władzy wykonawczej w realizację tych zadań powinna zostać ograniczona do procedur nadzorczych opartych na kryterium legalności; jest ona dopuszczalna tylko w wypadkach określonych w ustawach; 4) ingerencja prawodawcza w sferę samodzielności samorządu terytorialnego wymaga zachowania formy ustawowej oraz poszanowania zasady zupełności regulacji ustawowych; 5) wszelka ingerencja w sferę samodzielności jednostek samorządu terytorialnego musi być zgodna $\mathrm{z}$ zasadą proporcjonalności; 6) prawa i interesy jednostek samorządu terytorialnego podlegają ochronie sądowej" (wyrok TK z 12 marca 2007 r., sygn. akt K 54/05, także z 28 listopada 2013 r., sygn. akt K 17/12).

Wyjaśniając treść zasady samodzielności, sąd konstytucyjny wskazywał na konieczność wyróżnienia dwóch aspektów tego pojęcia. W aspekcie negatywnym oznacza ono wolność od arbitralnej ingerencji ze strony innych organów władzy publicznej. Natomiast samodzielność w aspekcie pozytywnym zakłada możliwość swobodnego wyboru działań podejmowanych w celu realizacji zadań publicznych. Samodzielność jednostek samorządu terytorialnego wyraża się m.in. w możliwości uchwalania statutu, wyboru organów, stanowienia prawa miejscowego, uchwalania budżetu i w prowadzeniu gospodarki finansowej (zob. wyrok TK z 29 października 2009 r., sygn. akt K 32/08).

Trybunał akcentował, że konstytucyjna zasada samodzielności samorządu terytorialnego jest wartością chronioną, ale nie ma charakteru absolutnego (tak m.in. wyrok TK z 4 maja 1998 r., sygn. akt K 38/97). Dopuszczalność ingerencji w sferę samodzielności jednostek samorządu terytorialnego jest uzależniona od spełnienia przesłanek o charakterze formalnym, jak i materialnym. Przesłanka formalna wymaga, aby wszelkie ograniczenia w zakresie samodzielności jednostek samorządu terytorialnego były wprowadzane wyłącznie na podstawie przepisów rangi ustawowej. Przesłanka materialna odnosi się natomiast do treści ograniczeń - muszą one znajdować uzasadnienie w konstytucyjnie określonych celach, konstytucyjnie określonych wartościach i nie mogą być nadmierne (wyroki TK z: 4 maja 1998 r., sygn. akt K 38/97; 24 listopada 1998 r., sygn. akt K 22/98). W nowszym orzecznictwie Trybunału Konstytucyjnego wyodrębniony został również - na tle art. 2 Konstytucji - zakaz nadmiernej ingerencji w sferę samodzielności jednostek samorządu terytorialnego (wyrok TK z 31 stycznia 2013 r., sygn. akt K 14/11).

\section{- 3. Ocena konstytucyjności}

Naruszenie konstytucyjnej pozycji gminy Wnioskodawca I powiązał z ingerencją ustawodawcy w sferę władztwa planistycznego, przysługującego jednostkom samorządu terytorialnego szczebla podstawowego. Jak wskazano w uzasadnieniu wniosku I, gminie przysługuje samodzielność w określaniu przeznaczenia i sposobu zagospodarowania terenów na jej obszarze. Stąd też wyznaczenie na poziomie ustawowym sztywnych zasad dotyczących lokalizacji elektrowni wia- 
trowych stanowi - w ocenie Wnioskodawcy I - niedopuszczalne ograniczenie władztwa planistycznego gminy, które obejmuje m.in. sprawy decydowania o lokalizacji elektrowni wiatrowej.

Przystępując do oceny zasadności powyższego zarzutu, należy w pierwszej kolejności scharakteryzować istotę władztwa planistycznego gminy. Zgodnie $\mathrm{z}$ art. 3 ust. 1 ustawy o planowaniu kształtowanie i prowadzenie polityki przestrzennej na terenie gminy, w tym stanowienie aktów planistycznych w zakresie planowania i zagospodarowania przestrzennego, zalicza się do zadań własnych gminy. Przyjmuje się, że powyższy przepis przyznaje jednostkom samorządu szczebla podstawowego tzw. władztwo planistyczne. Jest ono rozumiane jako kompetencja do samodzielnego kształtowania polityki przestrzennej w gminie, zgodnie z lokalnym interesem oraz potrzebą zapewniania ładu przestrzennego. W ramach tego władztwa gmina ustala przeznaczenie poszczególnych terenów położonych na obszarze gminy oraz zasady ich zagospodarowania. Do podstawowych instrumentów, za pomocą których jednostka samorządu terytorialnego wykonuje przysługujące jej władztwo planistyczne, zalicza się studium uwarunkowań i kierunków zagospodarowania przestrzennego gminy oraz miejscowe plany zagospodarowania przestrzennego. Ponadto jest ono realizowane przez wydawanie aktów indywidualnych, przede wszystkim decyzji o warunkach zabudowy i zagospodarowania terenu. Władztwo planistyczne sprawowane przez gminę wywiera istotny wpływ na sposób wykonywania prawa własności w stosunku do nieruchomości położonych na obszarze gminy. Regulacje przyjmowane w aktach planistycznych określają bowiem dopuszczalny sposób zagospodarowania terenu, warunki i parametry zabudowy itp. Taki charakter aktów planistycznych znajduje wyraźne potwierdzenie w przepisach ustawy o planowaniu - zgodnie z art. 6 ust. 1 tej ustawy wymienione akty kształtują, wraz z innymi przepisami, sposób wykonywania prawa własności nieruchomości.

Opisane uprawnienia o charakterze planistycznym zaliczają się do sfery zadań własnych gminy (art. 7 ust. 1 pkt 1 ustawy z dnia 8 marca 1990 r. o samorządzie gminnym, t.j. Dz. U. 2018, poz. 994, ze zm.). Natomiast zgodnie z art. 16 ust. 2 zdanie 2 Konstytucji zadania własne jednostki samorządu terytorialnego wykonują w ramach przysługującej im samodzielności („Przysługującą mu w ramach ustaw istotną część zadań publicznych samorząd wykonuje w imieniu własnym i na własną odpowiedzialność”). Za trafny należy w związku z tym uznać pogląd wyrażony przez Wnioskodawcę I, zgodnie z którym zadania w sferze władztwa planistycznego gminy wykonują w sposób samodzielny.

W tym miejscu podkreślenia wymaga jednak, że zarówno sfera zadań własnych, jak i samo pojęcie samodzielności samorządu ma charakter względny i ich zakres jest kształtowany w zasadniczym stopniu przez ustawodawcę. W odniesieniu do sfery zadań wykonywanych przez jednostki samorządu terytorialnego oznacza to, że ich sprecyzowanie jest dokonywane przez przepisy rangi ustawowej. Co więcej, przepisy Konstytucji nie wymieniają żadnego zadania, które 
powinno być wykonywane przez jednostki samorządu terytorialnego. Ustrojodawca ograniczył się jedynie do wskazania, że zadania własne realizowane przez samorządu terytorialny powinny obejmować zadania służące zaspokajaniu potrzeb wspólnoty samorządowej (art. 166 ust. 1 Konstytucji). Tym samym ustawodawcy przysługuje bardzo daleko posunięty zakres uznania w kwalifikowaniu określonych zadań jako zadań spoczywających na samorządzie. W odniesieniu do zadań związanych $\mathrm{z}$ władztwem planistycznym oznacza to, że przekazanie gminom tego zadania znajduje podstawy wyłącznie w przepisach rangi ustawowej, a nie konstytucyjnej. W szczególności ustawodawca jest uprawniony do określenia zakresu tego władztwa czy też sprecyzowania warunków, które muszą być zachowane przy realizacji uprawnień planistycznych. Ponadto ustawy wyznaczają instrumenty, za pomocą których władztwo to jest realizowane itd. Przepisy Konstytucji nie dają w konsekwencji podstaw do uznania za trafne twierdzenia przyjmowanego przez Wnioskodawcę I, że ustawodawca jest zobowiązany ukształtować przysługujące gminie władztwo planistyczne w ten sposób, że mieści się w nim decydowanie o lokalizacji elektrowni wiatrowych, jak również że samodzielność gminy w tym względzie nie może podlegać ograniczeniom. Trzeba ponadto zauważyć, że przyjmowane w ustawach regulacje co do kształtu władztwa planistycznego mogą podlegać zmianom. Zatem nawet jeżeli $\mathrm{w}$ dotychczasowym stanie prawnym władztwo planistyczne w zakresie ustalania lokalizacji elektrowni wiatrowych było w znacznym stopniu wykonywane przez gminę samodzielnie, to sytuacja ta nie oznacza, że ustawodawca nie może wprowadzić w tym względzie ograniczeń. Takim dopuszczalnym ograniczeniem są właśnie zasady dotyczące określania przez gminy lokalizacji na ich obszarze elektrowni wiatrowych, przyjęte $\mathrm{w}$ kwestionowanych $\mathrm{w}$ niniejszym postępowaniu przepisach ustawy o inwestycjach.

Przechodząc do kwestii przysługującej jednostkom samorządu terytorialnego samodzielności, należy wskazać, że jest ona kształtowana za pomocą ustaw. Wprawdzie obowiązek przyznania jednostkom samorządu istotnego zakresu swobody w realizacji zadań własnych ma rangę konstytucyjną, ale w rzeczywistości zakres swobody decyzyjnej jednostek samorządu jest wyznaczany na poziomie ustawowym. Ustawodawca jest legitymowany do sprecyzowania sposobu wykonywania zadań przez jednostki samorządu terytorialnego, co z punktu widzenia tychże jednostek stanowi ograniczenie przysługującej im samodzielności. Nie prowadzi to jednak do naruszenia konstytucyjnej zasady samodzielności samorządu, chyba że wprowadzone ograniczenia doprowadziły do naruszenia istoty tej samodzielności. Odnotować trzeba zarazem, że ani w doktrynie, ani w orzecznictwie Trybunału Konstytucyjnego nie został wyznaczony minimalny zakres samodzielności, który powinien zostać jednostkom samorządu zagwarantowany przy wykonywaniu zadań własnych. W praktyce zatem ustawodawca może na tyle szczegółowo wyznaczać sposób realizacji określonego zadania przez jednostkę samorządu, że pozostaje jej bardzo wąski zakres swobody decy- 
zyjnej w tym obszarze. Przy tym, w świetle dotychczasowego orzecznictwa Trybunału Konstytucyjnego, stan taki nie narusza zasady samodzielności samorządu terytorialnego. Jednocześnie prawodawca może w różny sposób kształtować zakres samodzielności w obrębie danego zadania publicznego. Na gruncie zadań związanych z planowaniem i zagospodarowaniem przestrzennym oznacza to, że w przypadku części kompetencji realizowanych w tym obszarze przez samorząd ustawodawca może przyznawać szeroki zakres swobody decyzyjnej, natomiast w odniesieniu do innych - znacznie węższy bądź też swoboda decyzyjna w ogóle może być wyłączona.

Odnosząc powyższe ustalenia do zarzutów sformułowanych przez Wnioskodawcę I, poczynić należy następujące spostrzeżenia. Po pierwsze, ponownie należy zaakcentować, że - czego wydaje się nie dostrzegać Wnioskodawca I - zakres władztwa planistycznego gminy ma charakter ograniczony. Jest ono kształtowane przez ustawy. Ustawodawca może przyznać gminie różny zakres swobody w wykonywaniu określonych kompetencji mieszczących się w ogólnie ujętym władztwie planistycznym. In concreto przepisy ustawowe mogą zatem wprowadzać istotne ograniczenia co do swobody decydowania przez gminy o lokalizacji elektrowni wiatrowych. Z przepisów Konstytucji nie można natomiast wywieść, że gminie musi zostać przyznany określony zakres tego władztwa i przykładowo - musi ono obejmować w pełni swobodne decydowanie o lokalizacji elektrowni wiatrowych. Po drugie, wprowadzenie tego typu ograniczeń stanowi ograniczenie samodzielności gminy, ale sfera samodzielności jednostek samorządu terytorialnego jest kształtowana w ramach ustaw. Co więcej, ustawodawca w sposób naturalny jest powołany do jej ograniczenia. Mianowicie, konkretyzując sposób wykonywania zadań przypisanych samorządowi terytorialnemu, przepisy ustawowe w istocie zawsze wprowadzają zarazem ograniczenia w swobodzie ich wykonywania. Granicę ingerencji w sferę samodzielności samorządu stanowi w tym wypadku naruszenie istoty samej samodzielności. Wnioskodawca I nie wykazał jednak, aby kwestionowane przepisy ingerowały w istotę samodzielności samorządu.

Przywołana argumentacja pozostaje aktualna także względem zarzutu naruszenia zasady proporcjonalności, wywodzonej z art. 2 Konstytucji. Na tle argumentacji podniesionej przez Wnioskodawcę I należy przyjąć, że zasada proporcjonalności zakazuje ustanawiania nadmiernych ograniczeń w sferze władztwa planistycznego gminy. Dotychczasowa praktyka ustrojowa, potwierdzona orzecznictwem Trybunału Konstytucyjnego, dowodzi jednak, że ustawodawca jest uprawniony tak dalece konkretyzować sposób wykonywania zadań własnych przysługujących jednostkom samorządu terytorialnego, że zakres przysługującej im swobody decyzyjnej w określeniu sposobu ich wykonywania pozostaje bardzo wąski a faktycznie wręcz żaden (np. wyrok TK z 26 listopada 2001 r., sygn. akt K 2/00, a także podobne stanowisko przyjęte w wyroku TK z 28 listopada 2013 r., sygn. akt K 17/12). Stan ten nie jest jednak uznawany za 
prowadzący do naruszenia zasady samodzielności samorządu, jak też nie budzi zastrzeżeń w świetle konstytucyjnej zasady proporcjonalności. Stąd też wprowadzenie kwestionowanych przez Wnioskodawcę I ograniczeń w sferze władztwa planistycznego gmin nie może być uznane za prowadzące do naruszenia zasady proporcjonalności, wywodzonej z art. 2 Konstytucji. Ewentualny zarzut niezgodności $\mathrm{z}$ art. 2 Konstytucji znajdowałby potwierdzenie tylko wówczas, gdyby przepisy wyznaczające sposób wykonywania przez gminę zadań własnych (in concreto - władztwa planistycznego) zostały uznane za naruszające istotę zasady samodzielności samorządu terytorialnego. Taka sytuacja nie ma jednak miejsca w przypadku kwestionowanych w niniejszym postępowaniu przepisów.

Mając na uwadze powyższe, Sejm wnosi o uznanie, że art. 4 ust. 1, art. 6 i art. 15 ust. 8-9 ustawy o inwestycjach są zgodne z zasadą proporcjonalności wywodzoną $\mathrm{z}$ art. 2 Konstytucji, a także $\mathrm{z}$ art. 16 ust. 2 i art. 165 ust. 1-2 Konstytucji.

\section{Utrata mocy decyzji o warunkach zabudowy dotyczących elektrowni wiatrowych wydanych przed wejściem w życie ustawy}

\section{- 1. Zarzuty wnioskodawców}

1.1. Kolejna grupa zarzutów dotyczy art. 14 ust. 5 i ust. 6 oraz art. 15 ust. 3, ust. 7 pkt 2, ust. 8 i ust. 9 ustawy o inwestycjach. Przepisy te regulują kwestię ważności decyzji o warunkach zabudowy dotyczących elektrowni wiatrowych, wydanych przed dniem wejścia w życie ustawy o inwestycjach (art. 14 ust. 6 ustawy), jak również dalszego biegu postępowań w sprawie wydania warunków zabudowy dotyczących elektrowni wiatrowych, wszczętych i niezakończonych przed dniem wejścia w życie ustawy (art. 14 ust. 5 ustawy), a także wyłączają możliwość lokalizacji elektrowni wiatrowych przewidzianych w planie miejscowym, niespełniających kryterium 10H (art. 15 ust. 3 ustawy). Ponadto uregulowano w nich sytuacje, kiedy to plany miejscowe mogą zawierać postanowienia dotyczące lokalizacji elektrowni wiatrowych i budynków mieszkalnych niespełniających kryterium $10 \mathrm{H}$ (art. 15 ust. 7-9 ustawy). Zarzuty w powyższym zakresie zostały podniesione przez obu wnioskodawców.

1.2. Wnioskodawca I wskazał, że kwestionowane przepisy ustawy pozbawiają inwestora możliwości lokalizacji i wybudowania elektrowni wiatrowej zgodnie z przepisami dotychczasowymi, mimo wydanej decyzji o warunkach zabudowy dopuszczającej budowę takiej elektrowni. Ustawa przewiduje także umorzenie postępowań w sprawie wydania warunków zabudowy dotyczących elektrowni wiatrowych, mimo że w dotychczasowym stanie prawnym spełnione były przesłanki lokalizacji takiego obiektu. Ponadto wyłączono możliwość wybudowania elektrowni wiatrowej niespełniającej kryterium $10 \mathrm{H}$ w sytuacji, gdy jej lokalizacja została uprzednio przewidziana w planie miejscowym. Zdaniem Wnioskodawcy I powyższe rozwiązania oznaczają, że zamierzenia inwestycyjne będące 
w toku dotyczące lokalizacji elektrowni wiatrowych podlegają ocenie z uwzględnieniem kryterium $10 \mathrm{H}$, które jednak nie obowiązywało w momencie podejmowania inwestycji i inwestorzy nie przewidywali jego wprowadzenia. Tym samym art. 14 ust. 5 i ust. 6 , art. 15 ust. 3, ust. 8 i ust. 9 ustawy uniemożliwiają dokończenie inwestycji w zakresie budowy elektrowni wiatrowych. Prowadzi to do naruszenia zasady ochrony zaufania do państwa, zasady ochrony praw nabytych oraz zasady ochrony interesów w toku, wywodzonych z art. 2 Konstytucji, a nadto jest niezgodne $\mathrm{z}$ art. 5, art. 10 ust. 1 i ust. 2, art. 20, art. 22, art. 32 ust. 1 i art. 64 Konstytucji.

Uzasadniając naruszenie zasady ochrony zaufania do państwa, Wnioskodawca I stwierdził, że w momencie wydania warunków zabudowy (a także w chwili wszczęcia procedury zmierzającej do wydania tej decyzji) inwestor podją działania przygotowawcze, w tym również zaangażował środki finansowe. Wyłączenie możliwości realizacji inwestycji pociąga za sobą niekorzystne skutki w tym względzie. Ma to miejsce, mimo że w momencie uzyskania warunków zabudowy (wszczęcia procedury w sprawie uzyskania warunków zabudowy) planowane przedsięwzięcie było zgodne z prawem. Powyższe zarzuty dotyczą także sytuacji, gdy możliwość lokalizacji elektrowni była przewidziana w planie miejscowym. Ustawodawca powinien zatem, dla uniknięcia niekorzystnych skutków dla podmiotów, które podjęły określone działania w związku z budową elektrowni wiatrowej, wprowadzić odpowiednie okresy przejściowe.

Kwestionowana regulacja narusza jednocześnie zasadę ochrony praw nabytych i interesów w toku. Uprawnienia do lokalizacji elektrowni wiatrowej na podstawie decyzji o warunkach zabudowy lub wynikające z ustaleń przyjętych w miejscowym planie zagospodarowania zostały przyznane inwestorom zgodnie z obowiązującymi przepisami prawa. Uprawnienia te zostały nabyte słusznie i nie mogą podlegać ograniczeniu ani zniesieniu bez przyznania pełnego ekwiwalentu za utracone uprawnienia. Podmioty te miały usprawiedliwione i racjonalne oczekiwanie, że planowane zamierzenie inwestycyjne będzie mogło być realizowane na danym terenie. Za odstąpieniem od realizacji wynikających stąd praw nie przemawiają w szczególności cele zamierzone przez ustawodawcę, tj. ochrona życia i zdrowia mieszkańców oraz ochrona środowiska. Ochronie konstytucyjnej w ramach wymogu respektowania interesów w toku - podlegają również ci inwestorzy, którzy wystąpili o ustalenie warunków zabudowy, a postępowanie w tym zakresie nie zostało zakończone w dniu wejścia w życie ustawy o inwestycjach.

Niezgodności z zasadą zrównoważonego rozwoju Wnioskodawca I upatruje w tym, że zaskarżone przepisy skutkują zahamowaniem rozwoju energetyki ze źródeł odnawialnych. Wejście w życie ustawy o inwestycjach prowadzi do przerwania wielu planowanych, jak również podjętych już inwestycji w zakresie elektrowni wiatrowych, choćby ich realizacja była korzystna z punktu widzenia ochrony środowiska, mieszkańców, gminy i całego społeczeństwa. Jednocześnie nie istnieją usprawiedliwione podstawy do wprowadzenia kryterium $10 \mathrm{H}$. 
Pozbawienie inwestorów możliwości realizacji inwestycji w zakresie lokalizacji i budowy elektrowni wiatrowych narusza również art. 20 i art. 22 Konstytucji. Inwestorzy zostali pozbawieni praw w zakresie prowadzenia działalności gospodarczej w sferze elektrowni wiatrowych. Następuje to mimo zaangażowania przez inwestorów znacznych środków finansowych, podjęcia określonych przedsięwzięć i uzyskania stosownych decyzji. Motywem wprowadzenia przez ustawodawcę powyższych regulacji było dostosowanie nowych inwestycji do kryterium $10 \mathrm{H}$. Tymczasem kryterium to nie zapewnia realizacji zamierzonego celu. Oddziaływanie elektrowni wiatrowej na środowisko powinno bowiem podlegać indywidualnej ocenie. W wielu przypadkach lokalizacja elektrowni bez zachowania kryterium $10 \mathrm{H}$ nie będzie negatywnie oddziaływać na mieszkańców lub środowisko. W konsekwencji nie występuje przesłanka ważnego interesu publicznego, która usprawiedliwiałaby ingerencję ustawodawcy w sferę wolności działalności gospodarczej.

W dalszej kolejności Wnioskodawca I uzasadnił zarzut naruszenia prawa własności. Wskazał, że inwestorzy dysponujący prawem do lokalizacji elektrowni wiatrowej na własnej nieruchomości (inwestorzy, którzy spełnili wszystkie przesłanki do nabycia takiego prawa) nie mogą zrealizować tej inwestycji, mimo iż przysługuje im jako właścicielom prawo do korzystania z nieruchomości. Podobna sytuacja dotyczy inwestorów, którzy uzyskali uprawnienia do korzystania z gruntu na mocy umowy zawartej z właścicielem, jak również - właścicieli tych gruntów. Kwestionowane przepisy naruszają przy tym istotę prawa własności, skoro wymienione prawa zostały ograniczone na tyle, że dalsze korzystanie $\mathrm{z}$ nich jest dalece utrudnione bądź niemożliwe.

Naruszenie konstytucyjnej zasady równości Wnioskodawca I powiązał z tym, że inwestorzy uprawnieni do dysponowania gruntem na cele budowlane $\mathrm{z}$ zamierzeniem lokalizacji i budowy elektrowni wiatrowej zostali zróżnicowani w przysługujących im prawach. Zróżnicowanie to wynika z przyjęcia kryterium $10 \mathrm{H}$ i prowadzi do wyodrębnienia grupy inwestorów, którzy mogą zrealizować planowane zamierzenie inwestycyjne ze względu na spełnienie kryterium $10 \mathrm{H}$, oraz grupy inwestorów, którzy wobec niespełnienia tego kryterium zostali pozbawieni możliwości lokalizacji elektrowni wiatrowej. Istotne jest przy tym, że w momencie podejmowania przedsięwzięcia nie obowiązywało kryterium $10 \mathrm{H}$. Wprowadzenie kryterium odległościowego zadecydowało o niezależnym od woli inwestorów i niedającym się wcześniej przewidzieć pozbawieniu praw realizacji inwestycji tylko ze względu na fakt, że inwestorzy ci zamierzali budować elektrownie wiatrowe w mniejszej odległości od zabudowań i obiektów środowiska niż pozostali inwestorzy.

Zarzut naruszenia art. 10 Konstytucji (zasada trójpodziału władzy) związany jest $\mathrm{z}$ wkroczeniem przez ustawodawcę $\mathrm{w}$ zakres działania zastrzeżony dla władzy wykonawczej. Mianowicie, art. 14 ust. 6 i ust. 7 ustawy przewiduje wygaśnięcie decyzji w sprawie warunków zabudowy dotyczących elektrowni wia- 
trowych. Decyzje w sprawie warunków zabudowy mają charakter indywidualny i konkretny. Organ władzy ustawodawczej nie ma kompetencji do wydawania rozstrzygnięć w przedmiocie uchylenia bądź utraty mocy prawnej decyzji administracyjnych. Zdaniem Wnioskodawcy I utrata mocy przez decyzje w sprawie warunków zabudowy powinna następować w trybie art. 162 ustawy z dnia 14 czerwca 1960 r. - Kodeks postępowania administracyjnego (t.j. Dz. U. 2018, poz. 2096, ze zm., dalej k.p.a.). Podejmowanie rozstrzygnięć w tym względzie jest zastrzeżone na rzecz organów władzy wykonawczej.

1.3. Argumentacja podniesiona przez Wnioskodawcę II dotycząca art. 14 ustawy jest w poważnym stopniu lakoniczna. W jego ocenie art. 14 ust. 5 ustawy przewiduje rażącą ingerencję w postępowania dotyczące decyzji o warunkach zabudowy lub w już istniejące decyzje, zakładając automatyczne umarzanie postępowań lub wygasanie decyzji. Artykuł 14 ust. 4-6 ustawy różnicuje sytuację prawną jednostek znajdujących się w tym samym czasie w podobnej sytuacji faktycznej w zależności od etapu procedury administracyjnej, a więc czy przed wejściem w życie ustawy nastąpiło zakończenie postępowania administracyjnego. Artykuł 14 ust. 6 i ust. 7 ustawy, przewidując wygaszenie decyzji administracyjnych z mocy prawa, prowadzi do naruszenia zasady ochrony zaufania do państwa. Wydawanie decyzji administracyjnych i prowadzenie postępowań administracyjnych należy do istoty władzy wykonawczej a nie ustawodawczej. Wygaszenie ostatecznej decyzji administracyjnej jest więc istotną ingerencją w status jednostek.

\section{Wzorce kontroli}

2.1. Analiza wzorców kontroli obejmujących wywodzoną z art. 5 Konstytucji zasadę zrównoważonego rozwoju, art. 20, art. 22, art. 32 ust. 1 i art. 64 Konstytucji została przedstawiona w pkt III.2 i pkt IV.2 stanowiska.

2.2. Zasada zaufania obywateli do państwa i stanowionego przez nie prawa (określana także jako zasada lojalności państwa wobec obywatela) stanowi jedną z zasad pochodnych, które - w świetle utrwalonego poglądu doktryny (np. W. Sokolewicz, M. Zubik, Komentarz do art. 2, op. cit., s. 111 i 127) oraz orzecznictwa sądu konstytucyjnego (np. wyroki TK z: 12 stycznia 2000 r., sygn. akt P 11/98; 21 czerwca 2011 r., sygn. akt P 26/10; 4 listopada 2015 r., sygn. akt K 1/14) - wynikają z zasady demokratycznego państwa prawnego (art. 2 Konstytucji).

Zgodnie $\mathrm{z}$ utrwalonym stanowiskiem sądu konstytucyjnego zasada zaufania w stosunkach między obywatelem a państwem „przejawia się m.in. w takim stanowieniu i stosowaniu prawa, by nie stawało się ono swoistą pułapką dla obywatela i aby mógł on układać swoje sprawy w zaufaniu, iż nie naraża się na prawne skutki, których nie mógł przewidzieć w momencie podejmowania decyzji i działań oraz w przekonaniu, iż jego działania podejmowane pod rządami obowiązującego prawa i wszelkie związane z nimi następstwa będą także i później uznane przez porządek prawny" (orzeczenie TK z 24 maja 1994 r., sygn. akt K 1/94; formuła ta konsekwentnie powtarzana była w późniejszym orzecznictwie). 
Zasada zaufania do państwa opiera się na zasadzie pewności prawa (co do kwestii wzajemnej relacji pomiędzy tymi zasadami zob. m.in. wyrok TK z 12 maja 2015 r., sygn. akt P 46/13). Celem zasady pewności prawa jest zapewnienie jednostce bezpieczeństwa prawnego, a więc sytuacji, w której może ona decydować o swoim postępowaniu na podstawie pełnej znajomości przesłanek działania organów państwa. Jednostka może ocenić konsekwencje swoich zachowań na gruncie obowiązującego w danym momencie porządku prawnego, jak również ma oczekiwanie, że prawodawca nie zmieni przepisów w sposób arbitralny. Powyższa zasada uwzględnia także legitymację prawodawcy do zmiany obowiązującego prawa. Z punktu widzenia jednostki do naruszenia zasady pewności prawa dochodzi w sytuacji, gdy rozstrzygnięcie prawodawcy ,jest dla jednostki zaskoczeniem, bo w danych okolicznościach nie mogła była go przewidzieć, szczególnie zaś wtedy, gdy przy jego podejmowaniu prawodawca mógł przypuszczać, że gdyby jednostka przewidywała zmianę prawa, byłaby inaczej zadecydowała o swoich sprawach" (wyrok TK z 14 czerwca 2000 r., sygn. akt P 3/00).

Zasady ochrony zaufania obywateli do państwa i zasada bezpieczeństwa prawnego nie mają charakteru bezwzględnego. Za odstąpieniem od ich respektowania może przemawiać inna wartość konstytucyjna, której realizacji w danych okolicznościach należałoby przyznać pierwszeństwo przed zasadą lojalności i zasadą bezpieczeństwa prawnego. Zarazem jednak konieczne jest uwzględnienie sytuacji prawnej jednostki poprzez ustalenie „na ile oczekiwanie jednostki, że nie narazi się ona na prawne skutki, których nie mogła przewidzieć w momencie podejmowania decyzji i działań, są usprawiedliwione. Jednostka musi zawsze liczyć się z tym, że zmiana warunków społecznych lub gospodarczych może wymagać nie tylko zmiany obowiązującego prawa, ale również niezwłocznego wprowadzenia w życie nowych regulacji prawnych. [...] Istotne znaczenie ma także horyzont czasowy działań podejmowanych przez jednostkę w danej sferze życia. Im dłuższa jest - w danej sferze życia - perspektywa czasowa podejmowanych działań, tym silniejsza powinna być ochrona zaufania do państwa i do stanowionego przez nie prawa" (wyrok TK z 7 lutego 2001 r., sygn. akt K 27/00).

2.3. Podobnie jak zasada ochrony zaufania obywateli do państwa także zasada ochrony praw nabytych zalicza się do zasad pochodnych wynikających z klauzuli demokratycznego państwa prawnego (art. 2 Konstytucji). Przyjmuje się, że u podstaw zasady ochrony praw nabytych znajduje się dążenie do zapewnienia jednostce bezpieczeństwa prawnego i umożliwienia jej racjonalnego planowania przyszłych działań (zob. wyrok TK 4 stycznia 2000 r., sygn. akt K 18/99).

Treścią powyższej zasady jest zakaz - adresowany do prawodawcy - arbitralnego znoszenia praw podmiotowych przysługujących jednostce lub innym podmiotom prywatnym występującym w obrocie prawnym, jak również niedopuszczalność ograniczenia tych praw w stopniu naruszającym istotę danego prawa bez pełnego ekwiwalentu uprawnień utraconych (zob. orzeczenie TK 
z 4 października 1989 r., sygn. akt K 3/88, oraz wyrok TK z 22 czerwca 1999 r., sygn. akt K 5/99). Pojęcie praw podmiotowych odnosi się zarówno do uprawnień o charakterze prywatnym, jak i publicznym. Poza zakresem stosowania tej zasady znajdują się natomiast sytuacje prawne, które nie mają charakteru praw podmiotowych (zob. wyrok TK z 22 czerwca 1999 r., sygn. akt K 5/99). Zasada ochrony praw nabytych obejmuje również ekspektatywy maksymalnie ukształtowane rozumiane jako „sytuacje, w których wprawdzie nie doszło do wydania aktu przyznającego prawo (tym bardziej - aktu stwierdzającego przysługiwanie prawa), ale spełnione zostały wszystkie przesłanki warunkujące nabycie danego prawa”. Trybunał uznaje, że rozszerzenie zasady ochrony praw nabytych na ekspektatywy jest uzasadnione, zwłaszcza gdy dotyczy uprawnień nabywanych w następstwie sukcesywnie spełnianych świadczeń (wyrok TK z 20 grudnia 1999 r., sygn. akt K 4/99).

Zasada ochrony praw nabytych nie ma charakteru absolutnego i nie wyklucza stanowienia regulacji mniej korzystnych dla jednostki. Jako okoliczność uzasadniającą odstąpienie od respektowania powyższej zasady sąd konstytucyjny uznaje w szczególności potrzebę zapewnienia realizacji innej wartości istotnej dla systemu prawnego (m.in. wyrok TK z 20 grudnia 1999 r., sygn. akt K 4/99). Trybunał wyraził ponadto pogląd, że: „ocena dopuszczalności wyjątków od zasady ochrony praw nabytych wymaga rozważenia, na ile oczekiwanie jednostki, iż prawa uznane przez państwo będą realizowane, jest usprawiedliwione”, jak również podkreślił, iż: „[i]stnieją dziedziny życia i sytuacje, w których jednostka musi liczyć się z tym, że zmiana warunków społecznych lub gospodarczych może wymagać zmian regulacji prawnych, w tym również zmian, które znoszą lub ograniczają dotychczas zagwarantowane prawa podmiotowe" (wyrok TK z 4 stycznia 2000 r., sygn. akt K 18/99). Ingerując w prawa nabyte, prawodawca powinien jednak wprowadzić rozwiązania prawne, które zawężają do niezbędnego minimum negatywne skutki dla zainteresowanych i umożliwiają im dostosowanie się do nowej sytuacji, w szczególności przez wprowadzenie odpowiedniej vacatio legis lub ustanowienie przepisów przejściowych, ułatwiających adresatom norm prawnych dostosowanie się do nowych regulacji (wyrok TK z 19 marca 2001 r., sygn. akt K 32/00).

W orzecznictwie Trybunału Konstytucyjnego został wypracowany mechanizm oceny, czy określone przepisy nie prowadzą do naruszenia zasady ochrony praw nabytych. Opiera się on na udzieleniu odpowiedzi na następujące pytania: 1) czy wprowadzone ograniczenia znajdują podstawę w innych normach, zasadach lub wartościach konstytucyjnych, 2) czy nie istnieje możliwość realizacji danej normy, zasady lub wartości konstytucyjnej bez naruszenia praw nabytych, 3) czy wartościom konstytucyjnym, dla realizacji których prawodawca ogranicza prawa nabyte, można w danej, konkretnej sytuacji przyznać pierwszeństwo przed wartościami znajdującymi się u podstaw zasady ochrony praw nabytych, 4) czy prawodawca podjął niezbędne działania mające na celu zapewnienie jed- 
nostce warunków do przystosowania się do nowej regulacji (m.in. wyroki TK z: 22 czerwca 1999 r., sygn. akt K 5/99; 26 lutego 2013 r., sygn. akt K 15/10; 24 marca 2015 r., sygn. akt K 19/14).

2.4. W bezpośrednim związku z zasadą ochrony zaufania obywateli do państwa oraz zasadą ochrony praw nabytych pozostaje zasada ochrony interesów w toku. Podobnie jak omówione wyżej zasady również zasada ochrony interesów $\mathrm{w}$ toku jest wywodzona $\mathrm{z}$ klauzuli demokratycznego państwa prawnego.

W świetle utrwalonego stanowiska sądu konstytucyjnego (m.in. wyroki TK z: 8 stycznia 2009 r., sygn. akt P 6/07; 5 lipca 2011 r., sygn. akt P 36/10; 23 lipca 2013 r., sygn. akt P 14/11; 10 lutego 2015 r., sygn. akt P 10/11) zasada ochrony interesów w toku nakazuje chronić zaufanie obywatela, który - zakładając stabilność wcześniejszych przepisów - zaplanował pewne posunięcia ekonomiczne i przystąpił do ich realizacji. Zmiana przepisów prawa określających warunki realizacji zaplanowanych posunięć ekonomicznych nie może naruszać interesów w toku osób, które podjęły pewne działania na gruncie wcześniejszych przepisów. Jeżeli przepisy prawa wyznaczały pewien horyzont czasowy dla zaplanowania i przeprowadzenia określonego przedsięwzięcia finansowego czy gospodarczego, ustawodawca nie może zmienić „reguł gry” przed końcem terminu, który sam wyznaczył.

Ochrona interesów w toku i wynikające $\mathrm{z}$ niej oczekiwania prawne mają z założenia charakter tymczasowy i przejściowy, określony ramami czasowymi wyznaczonymi przez ustawodawcę (zob. wyrok TK z 20 stycznia 2010 r., sygn. Kp 6/09). Spoczywający na ustawodawcy obowiązek poszanowania interesów w toku aktualizuje się wówczas, gdy łącznie zostaną spełnione trzy przesłanki: 1) przepisy prawa wyznaczają pewien horyzont czasowy dla realizowania określonych przedsięwzięć; 2) dane przedsięwzięcie jest rozłożone w czasie; 3) jednostka faktycznie rozpoczęła realizację danego przedsięwzięcia w okresie obowiązywania danej regulacji (wyrok TK z 25 listopada 1997 r., sygn. akt K 26/97). W razie zaistnienia powyższych przesłanek ustawodawca, zmieniając „reguły gry”, ma obowiązek ustanowienia przepisów przejściowych umożliwiających dokończenie przedsięwzięć ekonomicznych stosownie do przepisów obowiązujących w chwili ich rozpoczynania albo stworzenia obywatelowi innych możliwości dostosowania się do zmienionej sytuacji prawnej. Naruszenie - tak rozumianego - obowiązku poszanowania „interesów w toku” (a najczęstszą postacią takiego naruszenia jest brak jakichkolwiek przepisów przejściowych) należy traktować jako naruszenie zasady zaufania obywatela do państwa i stanowionego przez nie prawa, a tym samym naruszenie art. 2 Konstytucji.

Podkreśla się, że zasada ochrony interesów w toku nie może być postrzegana jako gwarancja niezmienności prawa, a w szczególności „wiecznego” trwania określonych uprawnień i przywilejów. Adresaci muszą liczyć się ze zmianą prawa, która może być uzasadniona, albo wręcz wymuszona, zmianą warunków społecznych lub gospodarczych. Ustawodawca ma możliwość ich ograniczania 
i znoszenia, a prawa, których trwanie nie jest ograniczone horyzontem czasowym, mogą podlegać modyfikacjom (wyrok TK z 16 września 2003 r., sygn. akt K 55/02).

2.5. Artykuł 10 ust. 1 Konstytucji wyraża zasadę podziału władzy („Ustrój Rzeczypospolitej Polskiej opiera się na podziale i równowadze władzy ustawodawczej, władzy wykonawczej i władzy sądowniczej”). Zasada ta stanowi jedną z podstaw ustrojowych Rzeczypospolitej, o czym świadczy zarówno jej umiejscowienie w rozdziale I Konstytucji, jak również odwołania do niej zawarte w preambule ustawy zasadniczej („ustanawiamy Konstytucję Rzeczypospolitej Polskiej jako prawa podstawowe dla państwa oparte na [...] współdziałaniu władz”).

Przyjmuje się, że art. 10 Konstytucji zawiera dwa aspekty zasady podziału władzy - przedmiotowy i podmiotowy. Uregulowany w art. 10 ust. 1 Konstytucji podział w aspekcie przedmiotowym oznacza, że w obrębie wszystkich zadań (kompetencji) realizowanych przez państwo należy wyodrębnić sferę kompetencji polegających odpowiednio na stanowieniu prawa, stosowaniu prawa oraz rozstrzyganiu sporów prawnych (zob. wyrok TK z 19 lipca 2005 r., sygn. akt K 28/04). Z kolei uregulowany w ust. 2 tego artykułu podział w aspekcie podmiotowym wskazuje organy realizujące zadania w ramach tak wyodrębnionych sfer („Władzę ustawodawczą sprawują Sejm i Senat, władzę wykonawczą Prezydent Rzeczypospolitej Polskiej i Rada Ministrów, a władzę sądowniczą sądy i trybunały"). Przyjmuje się, że w przypadku organów władzy ustawodawczej wyliczenie zawarte w ust. 2 ma charakter enumeratywny, w przypadku zaś władzy sądowniczej i władzy wykonawczej - otwarty (zob. L. Garlicki, Polskie prawo konstytucyjne. Zarys wykładu, Warszawa 2012, s. 71, oraz P. Sarnecki, Komentarz do art. 10 [w:] Konstytucja Rzeczypospolitej Polskiej. Komentarz, t. I, red. L. Garlicki, M. Zubik, Warszawa 2016, s. 335). Obok opisanego wyżej podziału władz $\mathrm{w}$ aspekcie przedmiotowym i podmiotowym wyodrębnić można nadto podział władz w aspekcie personalnym, mający przeciwdziałać sytuacji, w której ta sama osoba będzie pełniła funkcje w różnych segmentach władzy (w tym względzie zob. przepisy Konstytucji ustanawiające zasadę incompatibilitas).

Elementem omawianej zasady, wyrażonym expressis verbis w art. 10 ust. 1 Konstytucji, jest równowaga władz. Znajduje ona wyraz w wyposażeniu organów państwa w mechanizmy pozwalające jednym organom wpływać („hamować”) na działalność innych władz. Może to dotyczyć relacji między organami wywodzącymi się z różnych segmentów władzy (np. oddziaływanie Prezydenta RP względem parlamentu), jak i organów zaliczanych do tego samego segmentu władzy (np. relacje między Prezydentem RP a Radą Ministrów). W orzecznictwie Trybunału Konstytucyjnego wskazuje się, że równoważenie się władz „oznacza oddziaływanie władz na siebie, wzajemne uzupełnianie swych funkcji przez organy i wyraża się zarówno we współpracy władz ze sobą, jak i w ich wzajemnej kontroli, a także przejawia się w możliwościach prowadzenia dialogu między nimi. [...] Trybunał uznaje, że istotą zasady podziału i równowagi wła- 
dzy jest nie tyle funkcjonalny podział władzy, ile stan równoważenia się władz" (wyrok TK z 15 stycznia 2009 r., sygn. akt K 45/07).

\section{- 3. Analiza konstytucyjności}

3.1. W pierwszej kolejności należy odnieść się do zarzutu dotyczącego utraty mocy prawnej przez decyzje o warunkach zabudowy dotyczące elektrowni wiatrowych, wydane przed wejściem w życie ustawy o inwestycjach, oraz zarzutu dotyczącego umorzenia wszczętych uprzednio postępowań w sprawie wydania takich decyzji.

Trzeba zwrócić uwagę, że rozwiązania zawarte w kwestionowanych przez obu wnioskodawców regulacjach przewidujących uchylenie mocy prawnej decyzji o warunkach zabudowy w sprawie elektrowni wiatrowych, jak również umorzenie postępowań w sprawie o wydanie takich decyzji są podyktowane następującymi okolicznościami. Po pierwsze, ustawa o inwestycjach wprowadziła nowe zasady dotyczące lokalizacji elektrowni wiatrowych. Od wejścia w życie powyższej ustawy budowa tego typu obiektów jest dopuszczalna wyłącznie na terenie, dla którego obowiązuje miejscowy plan i zarazem plan ten dopuszcza lokalizację na danym terenie elektrowni wiatrowych. Ponadto budowa elektrowni wiatrowej może nastąpić wyłącznie w sytuacji, gdy jej lokalizacja spełnia kryterium $10 \mathrm{H}$. Przy czym ustalenia przyjęte w miejscowym planie, dopuszczającym lokalizację elektrowni wiatrowej, muszą być zgodne z kryterium 10H. Dążąc do zapewnienia, że przedsięwzięcia w zakresie lokalizacji i budowy elektrowni wiatrowych realizowane w okresie obowiązywania ustawy będą spełniały powyższe zasady, w tym zwłaszcza wymóg lokalizacji elektrowni tylko na podstawie miejscowego planu oraz zgodność z kryterium $10 \mathrm{H}$, ustawodawca przewidział zasadę bezpośredniego działania nowego prawa. Stąd do inwestycji jeszcze nie zrealizowanych, w aspekcie lokalizacji elektrowni wiatrowych, znajduje zastosowanie zasada ustalenia lokalizacji elektrowni wiatrowej w miejscowym planie oraz kryterium $10 \mathrm{H}$. Dotyczy to również sytuacji, gdy inwestor legitymuje się warunkami zabudowy dopuszczającymi budowę elektrowni wiatrowej niespełniającej kryterium $10 \mathrm{H}$. Jako że decyzje te dopuszczają realizację inwestycji, która w świetle aktualnie obowiązujących przepisów nie może mieć miejsca, adekwatnym środkiem prawnym pozostaje pozbawienie ich mocy prawnej.

Po drugie, wprowadzając zasadę bezpośredniego działania nowego prawa ustawodawca zobowiązany jest zarazem uwzględniać uprawnienia przysługujące podmiotom prawa, powstałe na gruncie dotychczasowego stanu prawnego. Jeżeli zatem określone uprawnienia związane z lokalizacją, budową czy eksploatacją elektrowni wiatrowej zostały w pełni ukształtowane pod rządami dotychczasowych przepisów, to ustawodawca powinien takie uprawnienia uwzględniać, a ich ewentualna modyfikacja czy też zniesienie musi znajdować szczególne oparcie w wartościach konstytucyjnych. Powyższe założenie realizuje regulacja zawarta w ustawie o inwestycjach, w świetle której pozwolenia na budowę dotyczące 
elektrowni wiatrowych, wydane przed dniem wejścia w życie ustawy zachowują moc, o ile w ciągu 5 lat od dnia wejścia w życie ustawy wydana zostanie decyzja o pozwoleniu na użytkowanie (art. 13 ust. 2 ustawy w aktualnym brzmieniu).

Po trzecie, dopuszczalność - na gruncie stanu prawnego obowiązującego przed wejściem w życie ustawy o inwestycjach - określenia lokalizacji elektrowni wiatrowej na podstawie decyzji o warunkach zabudowy należy postrzegać jako rozwiązanie wyjątkowe. Zgodnie $\mathrm{z}$ art. 4 ust. 1 ustawy o planowaniu ustalenie przeznaczenia terenu oraz sposobów zagospodarowania i warunków zabudowy terenu następuje w miejscowym planie zagospodarowania przestrzennego. Obszar pokrycia obszaru Polski miejscowymi planami pozostaje jednak relatywnie niewielki. Stąd przypisanie zasadzie wyrażonej w art. 4 ust. 1 ustawy o planowaniu charakteru bezwzględnego prowadziłoby do sytuacji, w której znaczna część działek byłaby wyłączona z możliwości zabudowy z tego tylko względu, że dla danego obszaru nie obowiązuje miejscowy plan. Dążąc do uniknięcia powyższej sytuacji, ustawodawca dopuścił - jako formę zastępczą - możliwość ustalenia sposobu zagospodarowania terenu i dopuszczalnych warunków zabudowy także w przypadku braku miejscowego planu, co następuje w formie decyzji o warunkach zabudowy (art. 4 ust. 2 pkt 2 ustawy o planowaniu). Uzyskanie decyzji o warunkach zabudowy jest zatem konieczne, w szczególności gdy planowana jest zmiana zagospodarowania terenu polegająca na budowie obiektu budowlanego lub wykonaniu innych robót budowlanych, zaś dana działka nie jest objęta miejscowym planem (art. 59 ust. 1 ustawy o planowaniu). Określenie w decyzji dopuszczalnego sposobu zagospodarowania nieruchomości oraz warunków zabudowy jest oparte na zasadzie dobrego sąsiedztwa, zgodnie z którą przedsięwzięcie budowlane dopuszczone na danej działce powinno stanowić kontynuację funkcji, parametrów, cech i wskaźników kształtowania zabudowy oraz zagospodarowania terenu, w tym gabarytów i formy architektonicznej obiektów budowlanych, linii zabudowy oraz intensywności wykorzystania terenu występujących na działkach sąsiednich. Ułomność decyzji o warunkach zabudowy, która ustalając sposób zagospodarowania terenu, ogranicza się wyłącznie do analizy cech zabudowy na sąsiednich działkach, jest szczególnie wyraźna w odniesieniu do lokalizacji elektrowni wiatrowych. W przypadku lokalizacji elektrowni wiatrowych na terenach, na których instalacje takie dotychczas nie występowały, nigdy nie zostanie spełniony warunek, aby tak określony sposób zagospodarowania terenu stanowił kontynuację funkcji, parametrów, cech i wskaźników kształtowania zabudowy, w tym gabarytów, obiektów budowlanych. Tego typu sposób zagospodarowania terenu nie występuje bowiem na działkach sąsiednich. Z tego względu, na co zwracano już uwagę w pkt III stanowiska, dopuszczalność lokalizowania elektrowni wiatrowych nie na podstawie miejscowych planów zagospodarowania przestrzennego, ale jedynie decyzji o warunkach zabudowy jest rozwiązaniem niepożądanym. Podkreślenia wymaga nadto, że ustawodawca wprowadził rozwiązania przypisujące pierwszeństwo 
miejscowego planu w stosunku do decyzji o warunkach zabudowy (art. 62 ustawy o planowaniu).

$\mathrm{Na}$ tle wskazanych uwarunkowań należy przeprowadzić ocenę przyjętych w ustawie o inwestycjach regulacji dotyczących ważności decyzji o warunkach zabudowy dotyczących elektrowni wiatrowych, wydanych przed dniem wejścia w życie ustawy (art. 14 ust. 6), jak również skutków wejścia w życie ustawy $\mathrm{w}$ stosunku do postępowań w sprawie wydania warunków zabudowy dotyczących elektrowni wiatrowych, wszczętych i niezakończonych przed dniem wejścia w życie ustawy (art. 14 ust. 5).

O braku zasadności podniesionych w tym względzie przez wnioskodawców zarzutów przesądza przede wszystkim okoliczność, że decyzja o warunkach zabudowy nie kreuje samodzielnie uprawnień w zakresie zagospodarowania objętej nią nieruchomości, mających charakter praw podmiotowych. Na poziomie ustawy o planowaniu kwestię skutków wynikających z decyzji o warunkach zabudowy określa jednoznacznie art. 63 ust. 2, zgodnie z którym decyzja o warunkach zabudowy nie rodzi praw do terenu. Treścią tej decyzji jest stwierdzenie dopuszczalności, z punktu widzenia przepisów prawa, określonego rodzaju zamierzenia inwestycyjnego wobec wskazanego terenu, nie przesądza ona natomiast możliwości realizacji inwestycji. Do uzyskania praw o charakterze podmiotowym konieczne jest wykazanie się prawem do dysponowania nieruchomością na cele budowlane, jak również spełnienie innych wymogów przewidzianych w prawie budowlanym (Komentarz do art. 63 ustawy o planowaniu i zagospodarowaniu przestrzennym, red. Z. Niewiadomski, 2018, Legalis), w tym w szczególności pozwolenia na budowę. W tym kontekście podkreśla się, że: „wnioskodawca po uzyskaniu pozytywnej decyzji nie będzie miał dodatkowych praw względem terenu, niż przed uzyskaniem decyzji" (Komentarz do art. 63 [w:] Ustawa o planowaniu i zagospodarowaniu przestrzennym, red. M.J. Nowak, 2012, Legalis). Powyższe stanowisko znajduje jednoznaczne oparcie w orzecznictwie - wskazuje się, że: „wydanie decyzji o warunkach zabudowy nie przesądza jeszcze, że do realizacji inwestycji w ogóle dojdzie. Dopiero bowiem po zatwierdzeniu projektu budowlanego i uzyskaniu pozwolenia na budowę inwestor może przejść do realizacji zamierzenia [...]. [decyzja o warunkach zabudowy - dopisek Z.G.] nie uprawnia do wykonania inwestycji” (wyrok NSA z 17 lipca 2009 r., sygn. akt II OSK 1186/08); „decyzja o warunkach zabudowy ma jedynie charakter wstępny $\mathrm{w}$ procesie inwestycyjnym, zakreślając najistotniejsze parametry przedsięwzięcia a jednocześnie wskazując potencjalnemu inwestorowi, czy jest w ogóle możliwe zrealizowanie określonej koncepcji zabudowy i zagospodarowania terenu” (wyrok WSA w Szczecinie z 21 listopada 2012 r., sygn. akt II SA/Sz 581/12); „decyzja o warunkach zabudowy jest jedynie informacją o tym, czy określonego rodzaju inwestycja może być na danej nieruchomości zrealizowana"(wyrok WSA w Warszawie z 27 listopada 2006 r., sygn. akt IV SA/Wa 1711/06); „decyzja ustalająca warunki zabudowy nie nadaje się do wykonania. Wydanie takiej decyzji nie wią- 
że się bowiem dla stron z obowiązkiem działania, zaniechania, czy też nakazem znoszenia zachowania innych podmiotów. Decyzja ta nie wywołuje żadnych skutków materialnych" (wyrok WSA w Bydgoszczy z 13 września 2017 r., sygn. akt II SA/Bd 984/16).

Charakter decyzji o warunkach zabudowy w kształcie wynikającym z ustawy o planowaniu oznacza zatem, że decyzja ta nie ma charakteru prawnokształtującego i nie podlega ochronie jako prawo nabyte. Tym samym nie znajduje oparcia twierdzenie wnioskodawców, że z decyzji tej wynika prawo do określonego zagospodarowania terenu, a więc - in concreto - prawo do lokalizacji na niej elektrowni wiatrowej. Jeżeli zatem w analizowanym zakresie nie dochodzi do naruszenia zasady ochrony praw nabytych, to ustawodawca był legitymowany do przyjęcia zasady bezpośredniego działania nowego prawa. W rezultacie dopuszczalne było wprowadzenie zasady lokalizacji elektrowni wiatrowej wyłącznie na podstawie planu miejscowego, z pominięciem możliwości budowy elektrowni na podstawie wcześniej wydanych decyzji o warunkach zabudowy.

Przyjmując, że wydanie decyzji o warunkach zabudowy nie ma charakteru prawnokształtującego, to tym bardziej skutki takie nie mogą być wywodzone z faktu wszczęcia postępowania zmierzającego do wydania warunków zabudowy. Zatem także zarzuty dotyczące niedopuszczalnej ingerencji w sferę praw inwestorów, którzy wystąpili z wnioskiem o ustalenie warunków zabudowy, ale postępowanie w tym zakresie nie zakończyło się przed wejściem w życie ustawy, nie zasługują na uwzględnienie.

Należy zwrócić uwagę, że przewidując wygaśnięcie mocy decyzji o warunkach zabudowy, ustawodawca nie różnicuje, czy decyzja ta dopuszcza lokalizację elektrowni wiatrowej z uwzględnieniem kryterium $10 \mathrm{H}$, czy też przewidziana w niej lokalizacja elektrowni wiatrowych nie spełnia tego kryterium. Mogłoby to prowadzić do powstania wątpliwości, czy zasadne jest objęcie wygaśnięciem decyzji o warunkach zabudowy również tych lokalizacji, które spełniają kryterium $10 \mathrm{H}$. Skoro bowiem przewidziana w nich lokalizacja jest zgodna $\mathrm{z}$ ustawą o inwestycjach, to nie zachodzi konieczność ich wygaśnięcia, wynikająca z konieczności zapewnienia zgodności inwestycji z aktualnym stanem prawnym. Rysująca się w tym zakresie sprzeczność ma jedynie pozorny charakter. Prawodawca wprowadził bowiem zasadę lokalizacji elektrowni wiatrowych wyłącznie na podstawie planów miejscowych (art. 3 ustawy o inwestycjach). Jest to wyraz przyjętego założenia, że - ze względu na oddziaływanie elektrowni wiatrowej na otoczenie jej lokalizacja musi zostać przewidziana w planie miejscowym. Z kolei analiza lokalizacji elektrowni przeprowadzona $\mathrm{w}$ ramach postępowania o ustalenie warunków zabudowy ma jedynie fragmentaryczny charakter, ograniczając się do działek sąsiadujących bezpośrednio z planowaną inwestycją i z tego względu nie spełnia powyższego założenia. Na tym tle zastępczy charakter decyzji o warunkach zabudowy w stosunku do planu miejscowego staje się szczególnie wyraźny. Stąd też utrata mocy prawnej decyzji o warunkach zabudowy dotyczącej elektro- 
wni wiatrowej, choćby przyjęta lokalizacja spełniałaby kryterium $10 \mathrm{H}$, pozostaje w pełni zasadne.

Uwzględniając powyższe, Sejm wnosi o uznanie, że 14 ust. 5 i ust. 6 ustawy nie prowadzą do naruszenia zasady ochrony praw nabytych i interesów w toku, wywodzonych $\mathrm{z}$ art. 2 Konstytucji.

3.2. Zdaniem Wnioskodawcy I kwestionowane przepisy naruszają także zasadę równości. Zróżnicowanie inwestorów realizujących przedsięwzięcia w zakresie energetyki wiatrowej wynika z przyjęcia kryterium $10 \mathrm{H}$. W rezultacie zastosowania tego kryterium część inwestorów została pozbawiona możliwości budowy elektrowni wiatrowej (jeżeli zamierzona lokalizacja elektrowni nie jest zgodna z kryterium 10H), podczas gdy pozostała grupa inwestorów może podejmować przedsięwzięcia w tym zakresie (jeżeli zamierzona lokalizacja elektrowni jest zgodna z kryterium $10 \mathrm{H}$ ). We wniosku wskazano, że powyższe zróżnicowanie nie ma charakteru relewantnego. Tymczasem tylko zróżnicowanie sytuacji prawnej podmiotów podobnych odznaczające się charakterem relewantnym jest dopuszczalne w świetle konstytucyjnej zasady równości.

Powyższy zarzut nie zasługuje na uwzględnienie. Przede wszystkim kwestionowane przepisy nie wprowadzają zróżnicowania w wymiarze prawnym. W stosunku do wszystkich inwestorów w równym stopniu obowiązuje kryterium $10 \mathrm{H}$ (podobnie jak względem wszystkich inwestorów, przed wejściem w życie ustawy o inwestycjach nie obowiązywało kryterium 10H). Zróżnicowanie ma wyłącznie charakter faktyczny i wynika z odległości istniejącej zabudowy mieszkaniowej od miejsca, w którym inwestor planuje inwestycję w zakresie elektrowni wiatrowej. Takiego rodzaju zróżnicowanie ma charakter faktyczny i nie podlega ochronie z punktu widzenia konstytucyjnej zasady równości.

3.3. Zdaniem Wnioskodawcy I kwestionowane przepisy naruszają również zasadę zrównoważonego rozwoju.

Powołana w tym względzie przez Wnioskodawcę I argumentacja pozostaje zbliżona do uzasadnienia, jakie zostało przedstawione w odniesieniu do zarzutu niezgodności art. 4 ust. 1, art. $6 \mathrm{i}$ art. 7 ustawy o inwestycjach z zasadą zrównoważonego rozwoju (pkt IV stanowiska). Podtrzymując aktualność wyjaśnień przedstawionych w pkt IV.3.4 stanowiska, należy wyrazić pogląd, że Wnioskodawca I nie uzasadnił we właściwy sposób zarzutu naruszenia art. 5 Konstytucji, a tym samym nie zasługuje on na uwzględnienie. Zarazem ponownie należy wyrazić wątpliwość dotyczącą powoływania art. 5 Konstytucji jako wzorca kontroli ze względu na przypisywany temu przepisowi charakter normy programowej.

3.4. Wzorcami kontroli powołanymi przez wnioskodawców są również art. 20 i art. 22 Konstytucji. Należy wskazać w tym względzie, że kwestionowane przez Wnioskodawcę I przepisy wyznaczają warunki budowy określonych kategorii obiektów budowlanych, tj. elektrowni wiatrowych. Wymogi te odnoszą się w sposób jednolity do wszystkich podmiotów zamierzających podejmować przedsięwzięcia polegające na budowie elektrowni wiatrowych, a więc zarówno do osób 
fizycznych, podmiotów publicznych, jak i przedsiębiorców. Bez znaczenia pozostaje zatem, czy podmioty te prowadzą działalność gospodarczą, czy też. W tym stanie przepisy te nie mogą być uznane za skutkujące wprowadzeniem ograniczeń w sferze wolności działalności gospodarczej. Tym samym zasada wolności działalności gospodarczej (art. 20 Konstytucji), a także przepis określający dopuszczalne ograniczenia w obrębie tej zasady (art. 22 Konstytucji) nie mogą być uznane za adekwatne wzorce kontroli wobec zarzutu dotyczącego utraty mocy decyzji o warunkach zabudowy dotyczących elektrowni wiatrowych. Aktualna pozostaje w tej mierze argumentacja powołana w pkt III.3.2 oraz pkt IV.3.5 stanowiska.

3.5. W dalszej kolejności za oczywiście bezzasadny należy uznać zarzut naruszenia zasady podziału władzy. Odnosząc się to tego zarzutu, trzeba wskazać, że w zakresie kompetencji przysługujących ustawodawcy pozostaje stanowienie przepisów, które przewidują wygaśnięcie (utratę) mocy prawnej określonych kategorii decyzji administracyjnych (in concreto - decyzji o warunkach zabudowy w sprawie elektrowni wiatrowych). Takie działanie mieści się w sferze działania władzy ustawodawczej (co więcej - jest objęte istotą tej władzy), o ile tylko przybiera formy typowe dla działań legislatywy, a więc polega na stanowieniu norm o charakterze generalnym i abstrakcyjnym.

Należy zwrócić uwagę, że utrata mocy decyzji administracyjnych może przebierać charakter jednostkowy, a więc odnosić się do poszczególnych decyzji i konkretnych ich adresatów. Wówczas uchylenie decyzji jest skutkiem rozstrzygnięć o charakterze indywidualnym, podejmowanych przez organy władzy wykonawczej. Działanie takie mieści się w pełni w zakresie działania (istocie) władzy wykonawczej. Ewentualne wyposażenie Sejmu w uprawnienie do podejmowania tego typu rozstrzygnięć należałoby z tego punktu widzenia postrzegać jako naruszenie zasady podziału władz. Oznaczałoby bowiem przyznanie organowi władzy ustawodawczej - mimo braku podstaw konstytucyjnych - uprawnienia do podejmowania działań o charakterze indywidualnym. Zalicza się to do działań typowych dla organów władzy wykonawczej i z tego względu nie mieści się w pojęciu (funkcji) legislatywy.

Jednocześnie uchyleniu określonej kategorii decyzji administracyjnych może być nadany wymiar generalny i abstrakcyjny. W takim wypadku konieczne jest ustanowienie przepisu rangi ustawowej, który przewidywałby taki skutek. $\mathrm{Na}$ gruncie ustawy o inwestycjach przepisami takim są m.in. art. 14 ust. 5 i ust. 6 . Natomiast wydawanie aktów tego rodzaju nie może zostać przekazane na rzecz organów władzy wykonawczej.

Trzeba nadto odnieść się do argumentu podniesionego przez Wnioskodawcę I, zgodnie z którym uchylenie decyzji ustalającej warunki zabudowy dla elektrowni wiatrowej może nastąpić wyłącznie w trybie art. 162 k.p.a. Norma ta ma rangę ustawową. Oznacza to, że inny przepis tej samej rangi może przewidywać, że w określonych sytuacjach art. 162 k.p.a. nie będzie znajdować zastosowania. Powyższy skutek został przewidziany właśnie w art. 14 ust. 7 ustawy o inwestycjach. 
Należy zauważyć, że zarzut naruszenia art. 10 Konstytucji może zostać uznany za aktualny wyłącznie w odniesieniu do art. 14 ust. 5-6 ustawy o inwestycjach. Natomiast pozostałe przepisy wymienione przez Wnioskodawcę I, tj. art. 15 ust. 3 , ust. 8 i ust. 9, nie dotyczą problematyki utraty mocy przez decyzje o warunkach zabudowy dotyczących elektrowni wiatrowych. Stąd też postępowanie w zakresie obejmującym kwestię zgodności wymienionych przepisów z art. 10 Konstytucji powinno podlegać umorzeniu.

Uwzględniając powyższe, należy wyrazić stanowisko, że zarzuty dotyczące niezgodności art. 14 ust. 5-6 ustawy o inwestycjach z art. 10 Konstytucji nie zasługują na uwzględnienie.

3.6. Artykuł 15 ust. 8 ustawy, w brzmieniu zaskarżonym przez Wnioskodawcę I, wyznacza termin przejściowy wynoszący 36 miesięcy od daty wejścia w życie ustawy, w którym dopuszczono uchwalanie planów miejscowych przewidujących lokalizację budynku mieszkalnego albo budynku o funkcji mieszanej, w skład której wchodzi funkcja mieszkaniowa na podstawie dotychczasowych zasad, a więc bez uwzględnienia kryterium $10 \mathrm{H}$. W następstwie wejścia w życie ustawy zmieniającej zostało nadane nowe brzmienie art. 15 ust. 8 ustawy o inwestycjach. Zgodnie $\mathrm{z}$ aktualnym stanem prawnym dopuszcza się uchwalenie planów miejscowych przewidujących lokalizację budynków mieszkaniowych według dotychczasowego stanu prawnego w okresie 72 miesięcy od dnia wejścia w życie ustawy. Powyższe oznacza, że art. 15 ust. 8 ustawy, według stanu obowiązującego w chwili składania wniosku I, utracił moc prawną. W tym stanie wnosi się o umorzenie postępowania w zakresie obejmującym kontrolę zgodności z Konstytucją art. 15 ust. 8 ustawy ze względu na niedopuszczalność wydania orzeczenia.

3.7. Mając na względzie powyższe, Sejm wnosi o uznanie, że art. 14 ust. 5-6, art. 15 ust. 3, ust. 8 i ust. 9 ustawy o inwestycjach:

- są zgodne z zasadą ochrony zaufania do państwa, zasadą ochrony praw nabytych i zasadą ochrony interesów w toku, wywodzonych z art. 2 Konstytucji, zasadą zrównoważonego rozwoju, wywodzoną z art. 5 Konstytucji oraz art. 32 ust. 1 i art. 64 Konstytucji,

- nie są niezgodne $z$ art. 20 i art. 22 Konstytucji.

Jednocześnie Sejm wyraża stanowisko, że art. 14 ust. 5-6 ustawy o inwestycjach jest zgodny z art. 10 Konstytucji.

\section{Zakaz rozbudowy istniejących elektrowni wiatrowych, niespełniających kryterium $10 \mathrm{H}$}

\section{- 1. Zarzuty wnioskodawców}

1.1. Następny zarzut związany jest z regulacjami przyjętymi w art. 12 ustawy o inwestycjach. Przepisy te określają warunki użytkowania elektrowni wiatrowych 
istniejących w dniu wejścia w życie ustawy, które nie spełniają kryterium $10 \mathrm{H}$. W odniesieniu do takich elektrowni dopuszcza się jedynie przeprowadzenie ich remontu oraz wykonywanie innych czynności niezbędnych do prawidłowego użytkowania elektrowni, z wyłączeniem działań prowadzących do zwiększenia parametrów użytkowych elektrowni lub zwiększenia jej oddziaływań na środowisko. Wątpliwości w tym względzie zostały podniesione przez obu wnioskodawców.

1.2. Zdaniem Wnioskodawcy I regulacja zawarta w art. 12 ustawy ogranicza możliwość korzystania $\mathrm{z}$ istniejących elektrowni wiatrowych niespełniających kryterium $10 \mathrm{H}$ w ten sposób, że podmioty dysponujące tytułem prawnym do elektrowni wiatrowej są uprawnione wyłącznie do przeprowadzenia remontu tej elektrowni bądź też mogą wykonywać inne czynności niezbędne do prawidłowego użytkowania elektrowni. Nie mogą natomiast podejmować działań mających na celu zwiększenie parametrów użytkowych elektrowni lub prowadzących do zwiększenia jej oddziaływania na środowisko. W tym kontekście wnioskodawca podniósł zarzut niezgodności art. 12 ustawy z art. 5, art. 20, art. 22, art. 32 ust. 1 i art. 64 Konstytucji.

Naruszenie art. 64 Konstytucji zostało powiązane z tym, że wprowadzone ograniczenia ingerują w sferę prawa własności podmiotów prowadzących działalność w zakresie elektrowni wiatrowych, przy czym dochodzi do naruszenia istoty prawa własności. Podmioty te zostały bowiem pozbawione prawa do korzystania z przedmiotu własności, z wyjątkiem przeprowadzenia remontu oraz podejmowania innych czynności niezbędnych do prawidłowego użytkowania elektrowni.

Z kolei naruszenie przez kwestionowane przepisy art. 20 i art. 22 Konstytucji jest spowodowane nadmierną ingerencją w sferę wolności działalności gospodarczej. Przedsiębiorcy zostali pozbawieni prawa do prowadzenia działalności gospodarczej w zakresie użytkowania elektrowni wiatrowych w sposób, który nie jest uzasadniony z punktu widzenia potrzeb rynku i zmieniających się uwarunkowań ekonomicznych, technicznych i środowiskowych. Zwiększenie parametrów użytkowych elektrowni nie prowadzi automatycznie do zwiększenia jej negatywnego oddziaływania na środowisko, jak również na zdrowie i życie mieszkańców. Wprowadzone ograniczenia nie stanowią także środka zapewniającego - w sposób adekwatny - realizację celów założonych przez ustawodawcę.

Skutki wynikające z braku możliwości zwiększenia parametrów użytkowych elektrowni należy także postrzegać w kontekście ograniczeń w budowie nowych elektrowni, jakie wynikają z przyjęcia kryterium $10 \mathrm{H}$. Ponadto ograniczenie ustanowione $\mathrm{w}$ art. 12 ustawy może także prowadzić do zaburzenia porządku energetycznego państwa. W dalszej kolejności Wnioskodawca I wskazał, że restrykcje wynikające z kwestionowanego przepisu nie służą realizacji ważnego interesu publicznego. Przy czym interes ten nie może być utożsamiany z ochroną interesów (zdrowia i życia) okolicznych mieszkańców. Kwestionowana regulacja nie służy także - w odpowiednim stopniu - ochronie środowiska. 
Odnosząc się do zarzutu naruszenia zasady zrównoważonego rozwoju, Wnioskodawca wskazał, że wynika z niej obowiązek ochrony w równym stopniu praw i wolności człowieka, jak też ochrony środowiska, bez uszczerbku i ograniczeń dla rozwoju państwa i społeczeństwa. Zakaz wynikający z art. 12 ustawy prowadzi do zahamowania rozwoju w zakresie energetyki wiatrowej, w tym także rozwoju społecznego i cywilizacyjnego. Elektrownie objęte tym zakazem nie będą mogły być modernizowane w celu zwiększenia ich efektywności. Przy tym art. 12 ustawy dotyczy znacznej części istniejących obecnie elektrowni wiatrowych, jako że większość z nich nie spełnia kryterium $10 \mathrm{H}$.

Natomiast naruszenie zasady równości (art. 32 ust. 1 Konstytucji) wyraża się w tym, że art. 12 ustawy różnicuje podmioty prowadzące działalność w zakresie elektrowni wiatrowych na dwie grupy. Pierwsza $z$ nich obejmuje podmioty prowadzące elektrownie spełniające kryterium $10 \mathrm{H}$, druga - podmioty, dla których powyższe kryterium nie zostało spełnione. W stosunku do drugiej z wyróżnionych grup prawodawca wprowadził ograniczenia, o których mowa w art. 12 ustawy, mimo że nie znajdują one uzasadnienia w konieczności ochrony określonych wartości konstytucyjnych. W szczególności nie zostało wykazane, że wszystkie elektrownie wiatrowe niespełniające kryterium $10 \mathrm{H}$ szkodzą środowisku, życiu i zdrowiu ludzi. Wnioskodawca I stwierdził też, że zróżnicowanie w ramach danej grupy podmiotów musi mieć charakter proporcjonalny.

1.3. Wnioskodawca II wskazał, że proces inwestycyjny związany z budową elektrowni wiatrowej liczony do czasu oddania jej do eksploatacji jest przedsięwzięciem wieloletnim. Stąd zmiany przepisów dotyczących budowy i eksploatacji elektrowni wiatrowych powinny uwzględniać ekonomicznie i prawnie uwarunkowany czas trwania procesu inwestycyjnego, umożliwiający podmiotom działającym na rynku elektrowni wiatrowych dostosowanie się do nowych przepisów.

Brzmienie art. 12 ustawy uniemożliwia tzw. repowering, czyli modyfikację lub wyposażenie istniejących elektrowni wiatrowych w bardziej zaawansowane technologicznie urządzenia lub komponenty. Repowering jest zjawiskiem pozytywnym, pozwalającym uzyskać zmodernizowanym elektrowniom większą moc znamionową, wyższą sprawność oraz niższe koszty eksploatacyjne, przy jednoczesnym zmniejszeniu oddziaływania elektrowni na środowisko (mniejsze oddziaływanie akustyczne). W tym stanie art. 12 ustawy narusza zasadę ochrony zaufania obywatela do państwa. Przedsiębiorca użytkujący do tej pory elektrownię wiatrową na postawie prawomocnych i ostatecznych decyzji administracyjnych został drastycznie ograniczony w swojej dalszej działalności. Ponadto przepis ten jest niezgodny z zasadą równości, powodując nierówne traktowanie przedsiębiorców posiadających elektrownie wiatrowe w stosunku do innych przedsiębiorców prowadzących podobne lub zbliżone zakłady (elektrownie, zakłady przemysłowe, zakłady usługowe, środki transportu, itp.). Zdaniem Wnioskodawcy II nie występuje przy tym interes publiczny przemawiający za wpro- 
wadzeniem zakazu zwiększania parametrów użytkowych elektrowni wiatrowych eksploatowanych w dniu wejścia ustawy w życie, które nie spełniają wymogu minimalnej odległości od zabudowy mieszkalnej. Ponadto kwestionowany przepis narusza zasadę ochrony praw nabytych wynikających z decyzji o pozwoleniu na budowę. Jednym z nich jest uzyskanie pozwolenia zamiennego. Pozwolenia zamienne powinny być wydawane na podstawie przepisów dotychczasowych, skoro pierwotne pozwolenie na budowę zostały wydane również na podstawie tych przepisów. Inwestorzy, którzy otrzymali decyzję o pozwoleniu na budowę przez wejściem w życie przepisów ustawy, powinni mieć zagwarantowane, że na podstawie uprawnień z niej płynących będą mogli zrealizować swoją inwestycję nawet, jeśli z jakichkolwiek przyczyn konieczna będzie np. zmiana projektu budowlanego wymagająca uzyskania pozwolenia zamiennego w trybie art. 36a prawa budowlanego.

Na tym tle Wnioskodawca II sformułował zarzut naruszenia zasady ochrony zaufania obywateli do państwa i stanowionego przez nie prawa oraz zasady ochrony praw nabytych, wywodzonych $\mathrm{z}$ art. 2, w związku z art. 32 ust. 1 i ust. 2 Konstytucji.

\section{Wzorce kontroli}

1. Analiza wzorców kontroli obejmujących zasadę ochrony zaufania obywateli do państwa i stanowionego przez nie prawa oraz zasadę ochrony praw nabytych, wywodzonych z art. 2, jak również art. 5, art. 20, art. 22, art. 32 ust. 1 i ust. 2 oraz art. 64 Konstytucji została przedstawiona w pkt III.2 i IV.2 stanowiska.

\section{Analiza formalnoprawna}

3.1. Zarzut dotyczący zakazu rozbudowy istniejących elektrowni wiatrowych, niespełniających kryterium $10 \mathrm{H}$, został powiązany z art. 12 tej ustawy. Przepis ten, $\mathrm{w}$ dacie zainicjowania postępowania zarówno przez Wnioskodawcę I, jak i Wnioskodawcę II, miał następujące brzmienie: „W przypadku elektrowni wiatrowych użytkowanych w dniu wejścia w życie ustawy, niespełniających wymogów określonych w art. 4, dopuszcza się jedynie przeprowadzenie remontu oraz wykonywanie innych czynności niezbędnych do prawidłowego użytkowania elektrowni, z wyłączeniem działań prowadzących do zwiększenia parametrów użytkowych elektrowni lub zwiększenia jej oddziaływań na środowisko”.

Powyższy przepis został - po wszczęciu niniejszego postępowania - zmieniony na podstawie art. 3 pkt 4 ustawy zmieniającej, który nadał mu następujące brzmienie: „W przypadku elektrowni wiatrowych, niespełniających wymogów określonych w art. 4, dopuszcza się jedynie przeprowadzenie remontu oraz wykonywanie innych czynności niezbędnych do prawidłowego użytkowania elektrowni, z wyłączeniem działań prowadzących do zwiększenia mocy zainstalowanej elektrycznej lub zwiększenia jej oddziaływań na środowisko”. Ponadto w art. 12 ustawy o inwestycjach został dodany ust. 2, w brzmieniu: „W przypad- 
kach określonych w ust. 1, minimalna odległość elektrowni wiatrowej określona $\mathrm{w}$ art. 4 nie jest brana pod uwagę przy wydawaniu decyzji administracyjnych, wymaganych do wykonywania czynności określonych w ust. 1".

Porównując art. 12 ustawy w brzmieniu zakwestionowanym przez wnioskodawców z aktualnym stanem prawnym, wskazać należy, że niektóre elementy treściowe tego przepisu, istotne w kontekście sformułowanych w obu wnioskach zarzutów, zostały zmienione. W szczególności w stanie prawnym właściwym na dzień zainicjowania postępowania przed Trybunałem, art. 12 zakazywał podejmowania wszelkich działań prowadzących do zwiększenia parametrów użytkowych elektrowni wiatrowej. Natomiast według aktualnego stanu prawnego zakazuje się działań prowadzących do zwiększenia mocy zainstalowanej elektrycznej. Oznacza to, że zakres zakazów wprowadzonych przez kwestionowany przepis, relewantny dla oceny konstytucyjności, został zmieniony, a zarazem są one zredukowane w porównaniu z wcześniejszą regulacją.

W tym stanie należy stwierdzić, że kwestionowany przez obu wnioskodawców art. 12 ustawy o inwestycjach, w brzmieniu obowiązującym w datach wystąpienia $\mathrm{z}$ wnioskami, utracił moc prawną. Wynika to $\mathrm{z}$ nadania mu nowego, odmiennego brzmienia. Ponadto przepis ten został uzupełniony o treść normatywną wyrażoną w art. 12 ust. 2 ustawy o inwestycjach.

Zgodnie $\mathrm{z}$ art. 59 ust. 1 pkt 4 ustawy o TK, Trybunał umarza postępowanie, jeżeli akt normatywny w zakwestionowanym zakresie utracił moc obowiązującą przed wydaniem orzeczenia przez Trybunał, przy czym odbywa się to na posiedzeniu niejawnym (art. 59 ust. 1 ustawy o TK) bądź na rozprawie (art. 59 ust. 2 ustawy o TK). Uwzględniając powyższe postępowanie w zakresie, w jakim przedmiot kontroli stanowi art. 12 ustawy o inwestycjach, powinno podlegać umorzeniu, na podstawie art. 59 ust. 1 pkt 4 ustawy o TK.

3.2. Niezależnie od podniesionej w pkt 3.1 okoliczności skutkującej umorzeniem postępowania $\mathrm{w}$ zakresie kontroli konstytucyjności kwestionowanego art. 12 ustawy o inwestycjach należy zauważyć, że zarzut dotyczący zakazu rozbudowy istniejących elektrowni wiatrowych, niespełniających kryterium $10 \mathrm{H}$, nie zasługuje na uwzględnienie.

Ustawa o inwestycjach wprowadziła kryterium minimalnej odległości między elektrownią wiatrową a zabudową o funkcji mieszkaniowej. Kryterium to obowiązuje w stosunku do elektrowni wiatrowych, których ustalenie lokalizacji i budowa następuje (nastąpiła) dopiero po wejściu w życie ustawy. Respektując konsekwencje wynikające $\mathrm{z}$ zasady ochrony praw nabytych, ustawodawca przyjął z kolei, że kryterium $10 \mathrm{H}$ nie dotyczy elektrowni wiatrowych użytkowanych w dniu wejścia w życie ustawy o inwestycjach. W konsekwencji mogą one dalej być użytkowane na dotychczasowych zasadach, także gdy ich lokalizacja nie spełnia kryterium $10 \mathrm{H}$. Innym przejawem uwzględnienia ochrony praw nabytych w odniesieniu do elektrowni istniejących jest to, że nie odnosi się do nich zasada przyjęta $\mathrm{w}$ art. 3 ustawy o inwestycjach, zgodnie z którą dopuszcza się 
lokalizację elektrowni wiatrowej wyłącznie na podstawie miejscowego planu zagospodarowania przestrzennego.

Podmioty, które użytkowały elektrownię wiatrową przed dniem wejścia w życie ustawy o inwestycjach, legitymują się prawem do lokalizacji i użytkowania elektrowni odznaczającej się określonymi parametrami, w tym w szczególności dotyczącymi wysokości słupa elektrowni, całkowitej wysokości elektrowni (wraz z łopatami), zainstalowanej mocy, lokalizacji elektrowni uwzględniającej oddalenie od istniejącej zabudowy itp. Uprawnienia do lokalizacji elektrowni o tych parametrach wynikają z odpowiednich decyzji administracyjnych, tj. decyzji o środowiskowych uwarunkowaniach zgody na realizację przedsięwzięcia, decyzji o warunkach zabudowy i zagospodarowania terenu (w przypadku braku miejscowego planu zagospodarowania przestrzennego) oraz decyzji o pozwoleniu na budowę. W konsekwencji w świetle zasady ochrony praw nabytych ochronie podlega prawo do użytkowania - po wejściu w życie ustawy o inwestycjach - elektrowni wiatrowej o parametrach wyznaczonych w tych decyzjach. Natomiast z wymienionych decyzji nie wynika w żaden sposób uprawnienie do rozbudowy - w przyszłości - danej elektrowni, zwiększenia jej parametrów użytkowych, wysokości, zainstalowanej mocy itp. Oznacza to, że uprawnienia te - wbrew twierdzeniom wnioskodawców - nie są objęte zasadą ochrony praw nabytych.

Z tego względu przyszłe, niezrealizowane zamierzenia inwestycyjne nie podlegają ochronie prawnej w świetle art. 2 Konstytucji i wnioskodawcy nie mogą powoływać się na prawo do rozbudowy bądź zwiększenia parametrów użytkowych elektrowni w przyszłości, choćby w momencie budowy przez nich elektrowni takie zamierzenia inwestycyjne były dopuszczalne w świetle obowiązującego wówczas prawa, oczywiście po uzyskaniu koniecznych pozwoleń. Przesądzające jest jednak, że uprawnienia te miały wyłącznie charakter potencjalny i nie znajdowały oparcia w żadnych decyzjach administracyjnych. Tym samym ustawodawca był uprawniony do wprowadzenia ograniczeń w rozbudowie oraz w zwiększaniu parametrów użytkowych elektrowni wiatrowych użytkowanych w dniu wejścia w życie ustawy o inwestycjach.

Warto zauważyć, że analogiczna konstrukcja prawna została przyjęta w przypadku miejscowych planów zagospodarowania przestrzennego. Wejście w życie takiego planu wywołuje skutki prospektywne, natomiast jego postanowienia nie mogą - co do zasady - działać wstecz. Zatem wprowadzenie na podstawie miejscowego planu na danym obszarze zakazu zabudowy (który wynika np. z przeznaczenia danego obszaru na teren zieleni) nie oznacza automatycznie konieczności rozbiórki istniejącej tam zabudowy, mimo że w świetle aktualnego miejscowego planu jej sytuowanie na tym obszarze jest niedopuszczalne. Z powyższego rozwiązania wynika, że plan miejscowy nie wywołuje (i nie może wywoływać) skutków retrospektywnych. Jeżeli jednak w następstwie wejścia w życie planu niemożliwe stałoby się korzystanie z nieruchomości w dotychcza- 
sowy sposób, właścicielowi gruntu przysługuje rekompensata. Natomiast wejście w życie miejscowego planu przewidującego dla danego obszaru zakaz zabudowy oznacza, że istniejące przed wejściem w życie budowle nie będą mogły być rozbudowywane, gdyż takie działanie byłoby niezgodne z obowiązującym planem. Oznacza to zarazem, że potencjalne uprawnienie do rozbudowy takich obiektów, nawet jeśli przysługiwało w chwili ich wznoszenia (bądź później), nie podlega ochronie w świetle zasady praw nabytych. Tym samym, uwzględniając zasadę bezpośredniego działania nowego prawa, planowi miejscowemu mogą być przypisane skutki prospektywne w stosunku do obiektów budowlanych, które zostały zbudowane przed jego wejściem w życie. Tożsame zasady, jak już wskazywano, zostały wprowadzone w odniesieniu do elektrowni wiatrowych.

\section{Utrata mocy decyzji o pozwoleniu na budowę dotyczących elektrowni wiatrowych wydanych przed wejściem w życie ustawy}

\section{- 1. Zarzuty wnioskodawców}

1.1. Kwestionowany art. 13 ust. 2 i ust. 6 ustawy o inwestycjach reguluje kwestię ważności decyzji dotyczących pozwolenia na budowę elektrowni wiatrowych, wydanych przed dniem wejścia w życie ustawy (art. 13 ust. 2), jak również skutki braku uzyskania pozwolenia na użytkowanie wybudowanej elektrowni wiatrowej (art. 13 ust. 6). Pozwolenie na budowę elektrowni wiatrowej zachowuje moc, o ile w ciągu 3 lat od dnia wejścia w życie ustawy zostanie wydana decyzja o pozwoleniu na użytkowanie tej elektrowni. $Z$ kolei jeżeli w terminie 3 lat od wejścia w życie ustawy inwestor nie uzyska decyzji o pozwoleniu na użytkowanie elektrowni wybudowanej na podstawie takiej decyzji, wówczas wojewódzki inspektor nadzoru budowlanego - na koszt inwestora - nakazuje rozbiórkę wybudowanej części obiektu budowlanego. Zarzuty dotyczące niezgodności z Konstytucją art. 13 ust. 2 i ust. 6 ustawy wnieśli obaj wnioskodawcy.

1.2. Zdaniem Wnioskodawcy I kwestionowane przepisy prowadzą do „zdelegalizowania wydanych na rzecz inwestorów decyzji oraz decyzji, które dopiero zostaną wydane, lecz będą oparte o przepisy dotychczasowe - uzależniając ten skutek od różnych czynników, w tym od woli właściwego organu [...]. Wprowadzone przepisy umożliwiają przewlekanie działań organu administracji ze szkodą dla inwestora [...]. Przepis ten sprzyja działaniom korupcyjnym" (wniosek I, s. 58). Ponadto regulacje te nie służą osiągnięciu w proporcjonalny sposób celu założonego przez ustawodawcę, tj. zapewnienia ochrony zdrowia i życia ludzi oraz ochrony środowiska.

Wnioskodawca I wskazał, że moc prawna decyzji objętych zakresem obowiązywania art. 13 ust. 2 ustawy jest zależna od okoliczności, na które inwestor nie ma wpływu. Przy czym wygaśnięcie mocy prawnej decyzji wywołuje bardzo daleko idące skutki dla inwestora w postaci nakazu rozbiórki wybudowanej już części obiektu budowlanego. Wprowadzone ustawą przepisy przejściowe nie słu- 
żą ochronie uprawnień inwestorów, którzy rozpoczęli proces inwestycyjny bądź wystąpili o wydanie pozwolenia na budowę przed wejściem w życie ustawy. Co więcej, podmioty te nie są w stanie określić, czy uzyskają pozwolenie na użytkowanie wybudowanej elektrowni w terminie wskazanym w ustawie. W tym stanie kwestionowane przepisy naruszają zasadę ochrony zaufania do państwa.

Zarazem art. 13 ust. 2 i ust. 6 ustawy są niezgodne z zasadą ochrony praw nabytych, jako że wprowadzone ustawą kryterium $10 \mathrm{H}$ obejmuje również inwestycje będące $w$ trakcie budowy oraz inwestycje znajdujące się na etapie planowania, co do których trwa postępowanie o wydanie pozwolenia na budowę. W konsekwencji zaskarżony art. 13 ust. 2 ustawy może skutkować pozbawieniem inwestorów praw nabytych wynikających z decyzji o pozwoleniu na budowę.

Skarżone przepisy naruszają także zasadę proporcjonalności. Nie istnieją bowiem żadne uzasadnione podstawy dla wprowadzenia ograniczenia czasowego (3 lata) mocy prawnej wydanych na rzecz inwestorów pozwoleń na budowę. Przy tym, na gruncie dotychczasowego stanu prawnego, przystąpienie do użytkowania elektrowni wiatrowej nie było uzależnione od uzyskania pozwolenia na jej użytkowanie. Wnioskodawca I stwierdził w tym kontekście, że nałożone $\mathrm{w}$ ten sposób warunki legalności budowy elektrowni wiatrowej są środkiem niewspółmiernym do założonego celu i nieproporcjonalnie obciążają inwestorów.

1.3. Wątpliwości Wnioskodawcy II związane są z ustanowionym $\mathrm{w}$ art. 13 ust. 2 ustawy terminem na wydanie decyzji o pozwoleniu na użytkowanie. Termin wydania tej decyzji jest w dużym stopniu uwarunkowany czasem trwania postępowania administracyjnego, co pozostaje w gestii organu administracji, zaś podmiot postępowania dysponuje jedynie ograniczonym wpływem w tym zakresie. W razie nieuzyskania $\mathrm{w}$ terminie pozwolenia na użytkowanie organ wydaje nakaz rozbiórki elektrowni wiatrowej.

$\mathrm{Z}$ kolei na gruncie prawa budowlanego nie zostały przewidziane żadne regulacje dotyczące terminu oddania do użytkowania obiektu budowlanego. W konsekwencji prawo budowlane nie wyznacza także okresu, w jakim inwestor powinien uzyskać pozwolenie na użytkowanie (art. 37 prawa budowlanego). Na tym tle Wnioskodawca II wskazał na niezgodność art. 13 ust. 2 ustawy $\mathrm{z}$ art. 22 Konstytucji w związku $\mathrm{z}$ art. 32 ust. 1 i ust. 2 Konstytucji, albowiem przewiduje zastosowanie niezwykle drastycznego środka prawnego „prowadzącego do zniszczenia rozpoczętej inwestycji prowadzonej w ramach przygotowania do prowadzenia działalności gospodarczej" (wniosek II, s. 28).

\section{Wzorce kontroli}

Analiza wzorców kontroli obejmujących zasadę ochrony zaufania obywateli do państwa, zasadę ochrony praw nabytych oraz zasadę proporcjonalności, wywodzonych $\mathrm{z}$ art. 2 Konstytucji, jak również art. 22 i art. 32 ust. 1 Konstytucji została przedstawiona w pkt III.2, IV.2 i VI.2 stanowiska. 


\section{- 3. Analiza formalnoprawna}

Kwestionowany art. 13 ust. 2 i ust. 6 ustawy o inwestycjach został zmieniony w następstwie wejścia w życie ustawy zmieniającej. Modyfikacje treściowe wyrażają się przede wszystkim w wydłużeniu okresu, przez jaki zachowują moc prawną pozwolenia na budowę dotyczące elektrowni wiatrowych. O ile w stanie prawnym kwestionowanym przez wnioskodawców termin ten wynosił 3 lata, o tyle w obowiązującym stanie prawnym termin ten został ustalony na 5 lat. Zmiana ta została wprowadzona przez nadanie nowego brzmienia art. 13 ust. 2 ustawy (zob. art. 13 ust. 2 ustawy w brzmieniu obowiązującym na dzień wszczęcia niniejszego postępowania: „Pozwolenia na budowę dotyczące elektrowni wiatrowych, wydane przed dniem wejścia w życie ustawy oraz wydane na podstawie postępowania, o którym mowa w ust. 3, zachowują moc, o ile w ciągu 3 lat od dnia wejścia w życie ustawy wydana zostanie decyzja o pozwoleniu na użytkowanie" oraz art. 13 ust. 2 ustawy w aktualnym brzmieniu: „Pozwolenia na budowę dotyczące elektrowni wiatrowych, wydane przed dniem wejścia w życie ustawy oraz wydane na podstawie postępowania, o którym mowa w ust. 3, zachowują moc, o ile w ciągu 5 lat od dnia wejścia w życie ustawy wydana zostanie decyzja o pozwoleniu na użytkowanie").

Ponadto ustawodawca wprowadził zmiany dotyczące rozbiórki wybudowanej elektrowni w razie nieuzyskania pozwolenia na użytkowanie przez inwestora w terminie określonym w ustawie. Do okoliczności skutkujących odstąpieniem od wszczęcia rozbiórki elektrowni wiatrowej w przypadku nieuzyskania pozwolenia na użytkowanie ustawa zmieniająca zaliczyła - obok uzyskania nowego pozwolenia na budowę elektrowni w terminie roku od dnia utraty mocy dotychczasowego pozwolenia - także uzyskanie w tym terminie pozwolenia zamiennego. Zmiana ta została wprowadzona przez nadanie nowego brzmienia art. 13 ust. 6 ustawy (zob. art. 13 ust. 6 ustawy w brzmieniu obowiązującym na dzień wszczęcia niniejszego postępowania: „Wojewódzki inspektor nadzoru budowlanego nakazuje rozbiórkę wybudowanej części obiektu budowlanego, w przypadku nieuzyskania decyzji o pozwoleniu na użytkowanie, o której mowa w ust. 2, na koszt inwestora, chyba że inwestor uzyska - w terminie roku od dnia utraty mocy pozwolenia na budowę - nowe pozwolenie na budowę dotyczące tej elektrowni” oraz art. 13 ust. 6 ustawy w aktualnym brzmieniu: „Wojewódzki inspektor nadzoru budowlanego nakazuje rozbiórkę wybudowanej części obiektu budowlanego, w przypadku nieuzyskania decyzji o pozwoleniu na użytkowanie, na koszt inwestora, chyba że inwestor uzyska - w terminie roku od dnia utraty mocy pozwolenia na budowę - nowe lub zamienne pozwolenie na budowę dotyczące tej elektrowni”).

Przedstawione okoliczności oznaczają, że art. 13 ust. 2 i ust. 6 ustawy w brzmieniu kwestionowanym przez wnioskodawców utracił moc prawną. W tym stanie Sejm wnosi - na podstawie art. 59 ust. 1 pkt 4 ustawy o TK - o umorzenie postępowania w zakresie obejmującym kontrolę zgodności z Konstytucją art. 13 ust. 2 i ust. 6 ustawy ze względu na niedopuszczalność wydania wyroku. 


\section{Objęcie podatkiem od nieruchomości części technicznych elektrowni wiatrowych}

\section{- 1. Zarzuty wnioskodawców}

1.1. Kolejny z zarzutów związany jest ze zmianami dotyczącymi kwalifikacji elektrowni wiatrowej jako budowli w rozumieniu prawa budowlanego. W dotychczasowym stanie prawnym za budowlę uznawane były wyłącznie części budowlane elektrowni wiatrowej, natomiast w następstwie wejścia w życie ustawy o inwestycjach pojęcie budowli zostało rozciągnięte także na części techniczne elektrowni. Powyższe zmiany mają istotne znaczenie w kontekście określenia podstawy opodatkowania elektrowni wiatrowych podatkiem od nieruchomości. Wątpliwości w tym względzie zostały sformułowane przez obu wnioskodawców.

1.2. Wnioskodawca I wskazał, że w następstwie zmian wprowadzonych ustawą o inwestycjach powstały wątpliwości co do podstawy opodatkowania elektrowni wiatrowych podatkiem od nieruchomości. W stanie prawnym sprzed wejścia w życie ustawy o inwestycjach opodatkowaniu podatkiem od nieruchomości podlegały wyłącznie części budowlane elektrowni wiatrowej, takie jak fundamenty, maszty, wieże, słupy. Natomiast podatek od nieruchomości nie obejmował urządzeń technicznych służących bezpośrednio wytwarzaniu energii elektrycznej, takich jak generator, wirnik ze skrzydłami, skrzynia przekładniowa, komputer sterujący, transformator itp. Elementy te pozbawione były cech zbliżonych do budowli.

Z kolej ustawa o inwestycjach wprowadziła zmiany definicji budowli zawartej w art. 3 pkt 3 prawa budowlanego, co polegało na wykreśleniu słowa „elektrownie wiatrowe”. Zdaniem Wnioskodawcy I ustawodawca odstąpił w ten sposób od podziału części elektrowni wiatrowej na części budowlane oraz części techniczne i w rezultacie opodatkowaniu podatkiem od nieruchomości podlegają wszystkie elementy, na które składa się elektrownia wiatrowa. Zarazem brzmienie kwestionowanego przepisu nadal pozwala na przyjęcie interpretacji, zgodnie z którą części techniczne elektrowni wiatrowych (wirnik, skrzydła, transformator) nie powinny być traktowane jako części budowlane. Stąd kwestia przedmiotu opodatkowania podatkiem od nieruchomości w przypadku elektrowni wiatrowych pozostaje niejednoznaczna. Wątpliwości w tym względzie wzmaga dodatkowo przepis przejściowy zawarty w art. 17 ustawy o inwestycjach.

Na tym tle Wnioskodawca I wystąpił o stwierdzenie niezgodności art. 9 pkt 1 i art. 17 ustawy o inwestycjach z zasadą przyzwoitej legislacji wywodzoną z art. 2 Konstytucji oraz z art. 84 i art. 217 Konstytucji. Zasada przyzwoitej legislacji wyłącza możliwość wprowadzania przez prawodawcę zmian legislacyjnych, które powodować będą wątpliwości interpretacyjne. Zasada ta ma szczególne znaczenie w sferze obowiązków podatkowych, w tym zwłaszcza określenia przedmiotu opodatkowania. Według powyższej zasady stanowienie przepisów niejasnych i wieloznacznych jest sprzeczne z zasadą demokratycznego państwa prawnego. W analogiczny sposób Wnioskodawca I uzasadnił naruszenie art. 84 i art. 217 
Konstytucji. Z kolei w świetle wiedzy technicznej, jak i zasad przyjętych w prawie budowlanym, podatek od nieruchomości powinien obejmować wyłącznie części budowlane elektrowni wiatrowej. Kwestionowane przepisy naruszają zatem wynikającą z art. 84 i art. 217 Konstytucji gwarancję określenia przedmiotu opodatkowania na poziomie ustawy, stwarzając pole do rozbieżności w zakresie kwalifikowania elektrowni wiatrowych i ich części technicznych oraz budowlanych jako budowli, które objęte są podatkiem od nieruchomości.

1.3. Wątpliwości w aspekcie skutków prawnopodatkowych zmiany definicji budowli w odniesieniu do elektrowni wiatrowych sformułował także Wnioskodawca II. Jego zdaniem przyjęta w art. 3 pkt 3 prawa budowlanego definicja budowli - w odniesieniu do elektrowni wiatrowych - jest nieprecyzyjna. W konsekwencji powyższy przepis jest niezgodny z zasadą określoności przepisów prawnych (art. 2 Konstytucji), jak również z zasadą zaufania obywateli do państwa w związku z elementem zaskoczenia, jakim była dla podmiotów prowadzących działalność w zakresie elektrowni wiatrowych zmiana przepisów podatkowych dotyczących podatku od nieruchomości. Na tym tle sformułowany został wniosek o stwierdzenie niezgodności z Konstytucją art. 3 pkt 3 prawa budowlanego w brzmieniu nadanym przez ustawę o inwestycjach.

Uzasadniając powyższy zarzut, Wnioskodawca II wskazał, że w świetle ustawy z dnia 12 stycznia 1991 r. o podatkach i opłatach lokalnych (t.j. Dz. U. 2018, poz. 1445, ze zm.; dalej: ustawa o podatkach i opłatach) podstawę opodatkowania podatkiem od nieruchomości stanowi - w przypadku budowli lub ich części związanych z prowadzeniem działalności gospodarczej - ich wartość początkowa. Zdaniem Wnioskodawcy II przepisy ustawowe nie są w tym względzie precyzyjne, niemniej brzmienie art. 17 ustawy o inwestycjach zdaje się przesądzać, że od 2017 r. podatek od nieruchomości za elektrownie wiatrowe naliczany będzie zarówno za obiekt ściśle budowlany (wieża), jak i urządzenia techniczne (turbina). Przy czym wartość początkowa nowej turbiny wiatrowej przekracza 4-5 razy wartość wieży wraz z fundamentem. Skutkować to będzie pięciokrotnym zwiększeniem obciążeń podatkowych - z tytułu podatku od nieruchomości w zakresie elektrowni wiatrowych. W tym stanie uchwalone zmiany prowadzą do naruszenia interesów w toku właścicieli tych elektrowni wiatrowych, które zostały oddane do eksploatacji przed wejściem w życie ustawy o elektrowniach wiatrowych. Zdaniem Wnioskodawcy II przesądza to o niezgodności art. 3 pkt 3 prawa budowlanego z art. 2, art. 20, art. 22, art. 31 ust. 3 oraz art. 32 ust. 1 Konstytucji.

\section{- 2. Wzorce kontroli}

2.1. Analiza wzorców kontroli obejmujących art. 20, art. 22, art. 31 ust. 3 oraz art. 32 ust. 1 Konstytucji została przedstawiona w pkt III.2 stanowiska.

2.2. Zasada określoności prawa, nazywana także zasadą przyzwoitej legislacji, jest jedną z zasad pochodnych wywodzonych z klauzuli demokratycznego państwa prawnego. 
Zgodnie z utrwalonym poglądem sądu konstytucyjnego z zasady określoności wynika, że: „każdy przepis prawny winien być skonstruowany poprawnie z punktu widzenia językowego i logicznego. [...] Wymóg jasności oznacza nakaz tworzenia przepisów klarownych i zrozumiałych dla ich adresatów, którzy od racjonalnego ustawodawcy oczekiwać mogą stanowienia norm prawnych nie budzących wątpliwości co do treści nakładanych obowiązków i przyznawanych praw. Związana z jasnością precyzja przepisu winna przejawiać się w konkretności nakładanych obowiązków i przyznawanych praw tak, by ich treść była oczywista i pozwalała na wyegzekwowanie" (wyrok TK z 21 marca 2001 r., sygn. akt K 24/00). Wymóg posługiwania się przez prawodawcę precyzyjnymi przepisami jest ujmowany także jako takie ukształtowanie ich brzmienia, które umożliwia dekodowanie $\mathrm{z}$ nich jednoznacznych norm prawnych za pomocą uznanych na gruncie określonej kultury prawnej reguł interpretacji (zob. wyrok TK z 4 listopada 2015 r., sygn. akt K 1/14). Obok kryterium jasności i precyzji regulacji prawnej Trybunał wskazywał, że z zasady określoności może być także wywiedziony wymóg legislacyjnej poprawności przepisu (zob. wyrok TK z 19 grudnia 2012 r., sygn. akt K 9/12).

Trybunał podkreślał, że zasada określoności przepisów prawa nakazuje unikać stanowienia przepisów „W sposób nieprecyzyjny, niejednoznaczny i powodujący istotne wątpliwości prawne”, a także regulacji, które posługują się niezdefiniowanymi pojęciami, albo mają niezrozumiałą treść (m.in. wyrok TK z 19 listopada 2008 r., sygn. akt Kp 2/08), w tym przepisów niepozwalających obywatelowi na przewidzenie konsekwencji prawnych jego zachowań (wyrok TK z 22 maja 2002 r., sygn. akt K 6/02). Akcentuje się zarazem, że dla stwierdzenia niezgodności zaskarżonego przepisu z zasadą określoności nie wystarcza tylko i wyłącznie abstrakcyjne wskazanie jego niejasności, wynikającej z posłużenia się przez ustawodawcę wyrażeniem czy zwrotem niedookreślonym. Akty prawne i sformułowane $\mathrm{w}$ nich przepisy zawsze zawierają pojęcia w mniejszym lub większym stopniu niedookreślone. Sprzyja to uelastycznieniu porządku prawnego i uczynieniu go wrażliwym na zachodzące w rzeczywistości stany faktyczne. Jedynie kwalifikowana - tj. niedająca się usunąć uznanymi metodami wykładni nieostrość czy niejasność przepisu może stanowić podstawę stwierdzenia jego niekonstytucyjności (m.in. wyrok TK z 3 marca 2011 r., sygn. akt K 23/09).

W świetle orzecznictwa Trybunału kontrola konstytucyjności kwestionowanego przepisu z powodu jego niedookreśloności wymaga przeprowadzenia tzw. testu określoności prawa, na który składają się trzy kryteria: 1) precyzyjność regulacji prawnej, 2) jasność przepisu oraz 3) jego legislacyjna poprawność (zob. np. wyrok TK z 28 października 2009 r., sygn. akt Kp 3/09). Precyzyjność przepisu przejawia się w konkretności regulacji praw i obowiązków, tak by ich treść była oczywista i pozwalała na ich wyegzekwowanie. Precyzyjna regulacja prawna ma umożliwiać dekodowanie z przepisów jednoznacznych norm prawnych (a także ich konsekwencji) za pomocą reguł interpretacji przyjmowanych 
na gruncie danej kultury prawnej. Jasność przepisu oznacza nakaz tworzenia przepisów zrozumiałych dla ich adresatów. Adresaci przepisów prawnych mają prawo oczekiwać od racjonalnego prawodawcy stanowienia norm niebudzących wątpliwości co do nakładanych obowiązków lub przyznawanych praw. Poprawność przepisu sprowadza się do jego właściwej konstrukcji z punktu widzenia językowego i logicznego.

2.3. Kolejny z wzorców powołanych przez Wnioskodawcę I - art. 84 Konstytucji - ma następujące brzmienie: „Każdy jest obowiązany do ponoszenia ciężarów i świadczeń publicznych, w tym podatków, określonych w ustawie".

Powyższy przepis formułuje zasadę powszechności opodatkowania (ponoszenia innych świadczeń publicznych niż podatki), stanowiącą jedną z podstawowych zasad prawa finansowego. Wyraża się ona $\mathrm{w}$ tym, że podatek jako świadczenie o charakterze nieekwiwalentnym powinien obciążać wszystkich, tak by można było zaspokajać wspólne potrzeby (zob. Z. Ofiarski, Źródła prawa podatkowego i jego stanowienie oraz podstawowe formy [w:] System prawa finansowego. Prawo daninowe, t. 3, red. L. Etel, Warszawa 2010, s. 395). Artykuł 84 wspólnie z art. 217 Konstytucji wyraża zasadę władztwa daninowego (podatkowego), zgodnie z którą państwo może obciążać obywateli podatkami w celu realizacji zadań publicznych (zob. np. T. Dębowska-Romanowska, Istota i treść władztwa finansowego [w:] Konstytucja, ustrój, system finansowy państwa. Ksiega pamiatkowa ku czci prof. Natalii Gajl, Warszawa 1999, s. 345 i n.). W literaturze zauważa się, że oba wymienione przepisy „składają się na względnie koherentną konstrukcję tzw. władztwa podatkowego" i powinny być traktowane równorzędnie, a różnica między nimi dotyczy „rozłożenia akcentów”: art. 84 Konstytucji podkreśla stronę podmiotową obowiązku ponoszenia danin publicznych (powszechność), a art. 217 Konstytucji stronę przedmiotową (kompetencje państwa wykonywane obowiązkowo w formie ustawy; zob. W. Sokolewicz, Komentarz do art. 217 [w:] Konstytucja Rzeczypospolitej Polskiej. Komentarz, t. IV, red. L. Garlicki, Warszawa 2005, s. 5-9). Trzeba jednak podkreślić, że art. 84 Konstytucji akcentuje aspekt podmiotowy zasady powszechności opodatkowania, nie należy natomiast wywodzić $\mathrm{z}$ niego dyrektywy powszechności opodatkowania w znaczeniu przedmiotowym (zob. wyrok TK z 18 listopada 2014 r., sygn. akt K 23/12).

Artykuł 84 Konstytucji wyraża zasadę sprawiedliwości podatkowej i wyłączności ustawy w zakresie ustanawiania obowiązku ponoszenia ciężarów i świadczeń publicznych. Jakkolwiek $\mathrm{w}$ orzecznictwie trybunalskim brak $\mathrm{w}$ tym zakresie pełnej zgodności poglądów, sprawiedliwość podatkowa zasadniczo pojmowana jest jako reguła kształtowania podatków według zasady równości i powszechności (np. wyrok TK z 29 lipca 2014 r., sygn. akt P 49/13). Z zasady powszechności wynika, że obowiązek podatkowy spoczywa na wszystkich zobowiązanych podmiotach, zaś podatkiem objęte są wszystkie stany faktyczne, z którymi wiąże się obowiązek podatkowy. $Z$ zasady równości podatkowej wynika, że wszystkie podmioty, będące w takiej samej sytuacji ekonomicznej (w zakresie stanu majątko- 
wego, rodzajów źródeł przychodów i ich wielkości), powinny być opodatkowane równo (zob. wyrok TK z 8 października 2011 r., sygn. akt SK 2/10).

2.3. Ostatnim z powołanych wzorców kontroli jest art. 217 Konstytucji, w brzmieniu: „Nakładanie podatków, innych danin publicznych, określanie podmiotów, przedmiotów opodatkowania i stawek podatkowych, a także zasad przyznawania ulg i umorzeń oraz kategorii podmiotów zwolnionych od podatków następuje w drodze ustawy".

Przywołany artykuł formułuje zasadę wyłączności ustawy w zakresie prawa daninowego. Przyjmuje się, że ustrojodawca wprowadził bezwzględną wyłączność ustawy w sprawach wymienionych w art. 217 Konstytucji, pozostawiając ustawodawcy zwykłemu swobodę w zaliczaniu danin do poszczególnych kategorii oraz w określaniu nazw nakładanych danin. O ile art. 84 Konstytucji formułuje nakaz precyzyjnego ustalenia w ustawie wszystkich istotnych elementów stosunku daninowego, to art. 217 Konstytucji wskazuje, w odniesieniu do jakich elementów omawianego stosunku rozważany obowiązek regulacji w drodze ustawy ma charakter szczególny (np. wyrok TK z 7 września 2010 r., sygn. akt P 94/08). Z powołanego przepisu wynika, że ustawodawca powinien określić takie elementy konstrukcji podatków oraz innych danin publicznych, jak: podmiot, przedmiot i stawkę oraz ulgi i umorzenia oraz podmioty zwolnione (zob. B. Banaszak, Konstytucja Rzeczypospolitej Polskiej. Komentarz, Warszawa 2012, s. 1049). Trybunał Konstytucyjny stoi przy tym na stanowisku, że wyliczenie zawarte w art. 217 Konstytucji „nie ma charakteru wyczerpującego, co oznacza, że wszystkie istotne elementy stosunku daninowego powinny być uregulowane w ustawie” i to tak, „aby unormowanie ustawowe zyskało cechy kompletności, precyzji i jednoznaczności” (wyrok TK z 9 listopada 1999 r., sygn. akt K 28/98).

Wskazuje się, że art. 217 Konstytucji zalicza regulowanie spraw podatków do wyłączności ustawy, ale nie formułuje materialnych ograniczeń, które wyznaczyłyby treść i kierunki przyjmowanych rozwiązań - ustalenie tych treści i kierunków pozostawiono ustawodawcy (zob. J. Oniszczuk, Podatki i inne daniny w orzecznictwie Trybunału Konstytucyjnego, Warszawa 2001, s. 37-38). Tym samym art. 217 Konstytucji postrzegany samoistnie ustanawia wymóg drogi ustawowej dla regulacji wymienionych w nim elementów obowiązku podatkowego (daninowego), określając materię przewidzianej regulacji, ale nie odnosząc się do jej treści (zob. W. Sokolewicz. Komentarz do art. 217, op. cit., s. 9).

\section{- 3. Ocena konstytucyjności}

1. Wnioskodawca II powiązał zarzut dotyczący zmian w opodatkowaniu elektrowni wiatrowych $\mathrm{z}$ nadaniem przez ustawę o inwestycjach nowego brzmienia art. 3 pkt 3 prawa budowlanego. Mianowicie, art. 3 pkt 3 prawa budowlanego zawiera definicję budowli, obowiązującą na gruncie tej ustawy. Zarazem definicja ta znajduje zastosowanie również dla określenia przedmiotu opodatkowania podatkiem od nieruchomości. Zgodnie bowiem z art. 2 ust. 1 pkt 3 ustawy o po- 
datkach i opłatach, opodatkowaniu tym podatkiem podlegają budowle lub ich części związane z prowadzeniem działalności gospodarczej. Natomiast pojęcie budowli - na potrzeby określenia tego podatku - należy rozumieć zgodnie z jego znaczeniem przyjętym $\mathrm{w}$ prawie budowlanym (art. 1a ust. 1 pkt 2 ustawy o podatkach i opłatach).

Określając przedmiot opodatkowania podatkiem od nieruchomości w odniesieniu do elektrowni wiatrowych, prześledzić należy zmiany, którym podlegało brzmienie art. 3 pkt 3 prawa budowlanego. Przesądza to bowiem o zasadności zarzutów sformułowanych przez wnioskodawców. Przed wejściem w życie ustawy o inwestycjach, przepis ten miał - w części odnoszącej się do elektrowni wiatrowych - następujące brzmienie: „Ilekroć w ustawie jest mowa o: [...] budowli - należy przez to rozumieć każdy obiekt budowlany niebędący budynkiem lub obiektem małej architektury, jak: [...] części budowlane urządzeń technicznych (kotłów, pieców przemysłowych, elektrowni wiatrowych, elektrowni jądrowych i innych urządzeń)". Z kolei w następstwie zmiany wprowadzonej ustawą o inwestycjach, powyższy przepis uzyskał następujące brzmienie: „Ilekroć w ustawie jest mowa o: [...] budowli - należy przez to rozumieć każdy obiekt budowlany niebędący budynkiem lub obiektem małej architektury, jak: [...] części budowlane urządzeń technicznych (kotłów, pieców przemysłowych, elektrowni jądrowych i innych urządzeń)". Powyższej zmianie towarzyszyło również nadanie nowego brzmienia załącznika do prawa budowlanego w części obejmującej wiersz „Kategoria XXIX" - do obiektów mieszczących się w tej kategorii zostały zaliczone, poza wolnostojącymi kominami i masztami, także elektrownie wiatrowe.

O ile zatem w stanie prawnym obowiązującym do 15 lipca 2016 r. art. 3 pkt 3 prawa budowlanego bezspornie zaliczał do pojęcia budowli wyłącznie części budowlane elektrowni wiatrowych, natomiast poza jego zakresem pozostawiał części techniczne tych elektrowni, o tyle po wejściu w życie ustawy o inwestycjach pojęcie budowli obejmowało wszystkie elementy składające się na elektrownię wiatrową, a więc zarówno części budowlane, jak i części techniczne. Taki też był cel - wskazany w uzasadnieniu projektu ustawy o inwestycjach - zmian w obrębie art. 3 pkt 3 prawa budowlanego („W projekcie ustawy zaproponowano wykreślenie przepisu wprowadzającego podział elektrowni wiatrowych na części budowlaną i niebudowlaną. W proponowanym stanie prawnym cała elektrownia wiatrowa będzie obiektem budowlanym (budowlą)", druk sejmowy nr 315/VIII kad., uzasadnienie, s. 4).

Zmiana brzmienia art. 3 pkt 3 prawa budowlanego wywoływała nie tylko skutki w sferze prawa budowlanego, ale także konsekwencje prawnopodatkowe. Zgodnie z dominującym poglądem, czego wyrazem jest również stanowisko przedstawione we wnioskach inicjujących niniejsze postępowanie, od 1 stycznia 2017 r. podatek od nieruchomości naliczany był za wszystkie części elektrowni wiatrowych, a więc zarówno ich części budowlane, jak i części techniczne. Analogiczny pogląd został wyrażony w orzecznictwie sądowym (np. wyrok WSA 
w Bydgoszczy z 21 lutego 2017 r., sygn. akt I SA/Bd 866/16), choć stan prawny w tym zakresie budził jednocześnie liczne wątpliwości. Zostały one rozstrzygnięte w wydanym w składzie siedmioosobowym wyroku NSA z 22 października 2018 r. (sygn. akt II FSK 2983/17). NSA uznał w nim, że w stanie prawnym obowiązującym od 1 stycznia do 31 grudnia 2017 r. przedmiotem opodatkowania podatkiem od nieruchomości objęte były fundament i wieża oraz elementy techniczne elektrowni wiatrowej, o których mowa w art. 2 pkt 2 ustawy o inwestycjach.

2. Przepisy dotyczące opodatkowania elektrowni wiatrowych zostały ponownie zmienione w następstwie wejścia w życie ustawy zmieniającej. Zmiany w tym zakresie wprowadzono z mocą od 1 stycznia 2018 r. (art. 17 pkt 2 ustawy zmieniającej).

Przede wszystkim, ustawodawca przywrócił - w odniesieniu do elektrowni wiatrowych - pojęcie budowli w brzmieniu obowiązującym przed wejściem w życie ustawy o inwestycjach. Wiązało się to ze zmianą brzmienia art. 3 pkt 3 prawa budowlanego. Przepis ten - w omawianym zakresie - ma aktualnie następujące brzmienie: „Ilekroć w ustawie jest mowa o: [...] budowli - należy przez to rozumieć każdy obiekt budowlany niebędący budynkiem lub obiektem małej architektury, jak: [...] części budowlane urządzeń technicznych (kotłów, pieców przemysłowych, elektrowni jądrowych, elektrowni wiatrowych i innych urządzeń)".

Dla wykluczenia wątpliwości co do kwalifikacji poszczególnych części elektrowni wiatrowych zmieniona została również - wskutek wejścia w życie ustawy zmieniającej - definicja elektrowni przyjęta w ustawie o inwestycjach. Zgodnie z aktualnym brzmieniem art. 2 pkt 1 tej ustawy: „Użyte w ustawie określenia oznaczają: elektrownia wiatrowa - instalację odnawialnego źródła energii, składającą się z części budowlanej stanowiącej budowlę w rozumieniu prawa budowlanego oraz urządzeń technicznych, w tym elementów technicznych, w której energia elektryczna jest wytwarzana $\mathrm{z}$ energii wiatru, o mocy większej niż moc mikroinstalacji w rozumieniu art. 2 pkt 19 ustawy z dnia 20 lutego 2015 r. o odnawialnych źródłach energii”. Odpowiednia zmiana została także wprowadzona w załączniku do prawa budowlanego w części obejmującej wiersz „Kategoria XXIX”. W obowiązującym stanie prawnym kategoria ta obejmuje wolno stojące kominy i maszty oraz części budowlane elektrowni wiatrowych. Podkreślenia wymaga, że zmiana brzmienia art. 3 pkt 3 prawa budowlanego była nakierowana właśnie na wprowadzenie zmian w zakresie zasad opodatkowania podatkiem od nieruchomości elektrowni wiatrowych. W uzasadnieniu do projektu ustawy zmieniającej wskazano jednoznacznie, że: „wejście w życie zmiany dotyczącej art. 3 pkt 3 ustawy - Prawo budowlane, zawierającej definicję budowli oraz dotyczącej załącznika do tej ustawy, spowoduje wprowadzenie jednolitych i przejrzystych zasad opodatkowania podatkiem od nieruchomości. [...] automatycznie spowoduje zmianę w zakresie przedmiotu opodatkowania podatkiem od nieru- 
chomości na podstawie ustawy o podatkach i opłatach lokalnych. Fakt ten będzie miał wpływ na wysokość opodatkowania podatkiem od nieruchomości elektrowni wiatrowych, gdyż podatek ten będzie pobierany wyłącznie od ich części budowlanych" (druk sejmowy nr 2412/VIII kad., uzasadnienie, s. 4 i s. 32).

Opisane zmiany mają zasadnicze znaczenie dla oceny zasadności zarzutów sformułowanych przez obu wnioskodawców. W istocie bowiem w następstwie wejścia $\mathrm{w}$ życie ustawy zmieniającej rozwiązania prawne kwestionowane przez obu wnioskodawców przestały obowiązywać, a ustawodawca powrócił do zasad obowiązujących do 15 lipca 2016 r. Trzeba jednak w tym miejscu zwrócić uwagę, że obaj wnioskodawcy - formując analogiczny zarzut - w różny sposób wskazali przepisy ustawy o inwestycjach, z którymi jest on związany. Wnioskodawca I zakwestionował w tym względzie konstytucyjność art. 9 pkt 1 i art. 17 ustawy o inwestycjach, natomiast Wnioskodawca II - art. 3 pkt 3 i art. 82 ust. 3 pkt 5b prawa budowlanego. Stąd też konsekwencje wynikające $\mathrm{z}$ wejścia w życie ustawy zmieniającej trzeba odrębnie rozważyć na tle zarzutów sformułowanych przez Wnioskodawcę I oraz Wnioskodawcę II.

W przypadku przepisów powołanych przez Wnioskodawcę I (art. 9 pkt 1 i art. 17 ustawy o inwestycjach) żaden $\mathrm{z}$ nich nie został formalnie zmieniony w następstwie wejścia w życie ustawy zmieniającej. Artykuł 9 pkt 1 ustawy o inwestycjach jest przepisem zmieniającym, który nadawał nową treść art. 3 pkt 3 prawa budowlanego. Przepis ten został skonsumowany wraz z wejściem w życie ustawy o inwestycjach, skutkując wprowadzeniem odpowiednich zmian normatywnych $\mathrm{w}$ obrębie prawa budowlanego. Istotna zmiana w zakresie mocy prawnej art. 9 pkt 1 ustawy o inwestycjach nastąpiła jednak wraz z wejściem w życie ustawy zmieniającej. Skoro na jej podstawie art. 3 pkt 3 prawa budowlanego uzyskał brzmienie odmienne niż nadane w następstwie wejścia w życie art. 9 pkt 1 ustawy o inwestycjach, to ten ostatni utracił w konsekwencji moc prawną, nawet gdy nie nastąpiła jego formalna derogacja. Uwzględniając tę okoliczność, należy wnieść - na podstawie art. 59 ust. 1 pkt 4 ustawy o TK - o umorzenie postępowania w zakresie art. 9 pkt 1 ustawy o inwestycjach ze względu na niedopuszczalność wydania orzeczenia.

Z kolei art. 17 ustawy o inwestycjach („Od dnia wejścia w życie ustawy do dnia 31 grudnia 2016 r. podatek od nieruchomości dotyczący elektrowni wiatrowej ustala się i pobiera zgodnie z przepisami obowiązującymi przed dniem wejścia w życie ustawy") stanowi regulację przejściową. Przepis ten nakazuje przy ustaleniu przedmiotu opodatkowania podatkiem od nieruchomości za elektrownie wiatrowe za 2016 r. stosować zasady obowiązujące przed wejściem $\mathrm{w}$ życie ustawy o inwestycjach. Tym samym w przypadku elektrowni wiatrowych podatek od nieruchomości za 2016 r. obejmuje wyłącznie części budowlane tych elektrowni, nie zaś ich elementy techniczne. Stąd też wymieniony przepis w kontekście zarzutu sformułowanego przez Wnioskodawcę I może zostać powołany wyłącznie w aspekcie informacyjnym, jako wyznaczający ramy czasowe dla 
ustalenia okresu, w którym podatek od nieruchomości za elektrownie wiatrowe naliczany jest zarówno za części budowlane, jak i elementy techniczne. W żaden sposób zarzut sformułowany przez Wnioskodawcę I nie może jednak zostać powiązany z brzmieniem art. 17 ustawy. Stąd też postępowanie w tym zakresie powinno - na podstawie art. 59 ust. 1 pkt 3 ustawy o TK - podlegać umorzeniu ze względu na zbędność wydania orzeczenia w tym zakresie.

Natomiast w przypadku części przepisów zakwestionowanych przez Wnioskodawcę II, tj. art. 3 pkt 3 i wiersza XXIX tabeli stanowiącej załącznik do prawa budowlanego, to utraciły one moc prawną w następstwie nadania im nowego brzmienia przez odpowiednio art. 2 pkt 1 ustawy zmieniającej (zmiana dotycząca art. 3 pkt 3 prawa budowlanego) oraz art. 2 pkt 6 ustawy zmieniającej (zmiana dotycząca wiersza XXIX tabeli stanowiącej załącznik do prawa budowlanego). $\mathrm{Z}$ tego względu, na podstawie art. 59 ust. 1 pkt 2 ustawy o TK, postępowanie w zakresie obejmującym kontrolę zgodności z Konstytucją art. 3 pkt 3 oraz wiersza XXIX tabeli stanowiącej załącznik do prawa budowlanego podlega umorzeniu ze względu na niedopuszczalność wydania orzeczenia.

Wnioskodawca II zakwestionował ponadto zgodność z Konstytucją art. 82 ust. 3 pkt 5 b prawa budowlanego. Przepis ten reguluje kwestię objęcia nadzorem budowlanym elektrowni wiatrowych, sprawowanym przez wojewodę. Stanowisko w tym zakresie zostało przedstawione poniżej.

\section{Objęcie nadzorem budowlanym części technicznych elektrowni wiatrowych}

\section{- 1. Zarzuty Wnioskodawcy II}

Wątpliwości Wnioskodawcy II w odniesieniu do art. 3 pkt 3 prawa budowlanego związane są ze zmianą brzmienia tego przepisu wynikającą z wejścia w życie ustawy o inwestycjach. Artykuł 3 pkt 3 prawa budowlanego zawiera definicję budowli. We wcześniejszym stanie prawnym do budowli zaliczone były - w przypadku elektrowni wiatrowych - wyłącznie części budowlane tych obiektów, bez urządzeń technicznych. W konsekwencji turbina wiatrowa, na którą składa się gondola $\mathrm{z}$ generatorem oraz wirnik $\mathrm{z}$ łopatami, nie była objęta pojęciem budowli. Natomiast po wejściu w życie ustawy o inwestycjach pojęciem budowli objęto także wszystkie części techniczne elektrowni wiatrowych. Wnioskodawca II wskazał, że prawodawca przyjął w tym względzie odmienną kwalifikację w porównaniu z urządzeniami technicznymi stosowanymi w energetyce konwencjonalnej (kotły, piece). Urządzenia te nie stanowią budowli i z tego względu nie są poddane nadzorowi budowlanemu.

Zdaniem Wnioskodawcy II art. 3 pkt 3 prawa budowlanego wprowadza nieuzasadnione ograniczenie swobody działalności gospodarczej oraz równego traktowania przedsiębiorców ze względu na wykorzystywany w prowadzonej działalności gospodarczej rodzaj urządzeń technicznych służących do wytwarza- 
nia energii elektrycznej. Wnioskodawca II stwierdził, że nierówność wyraża się w odmiennym zakresie nadzoru budowlanego sprawowanego w odniesieniu do elektrowni wiatrowych oraz pozostałych rodzajów elektrowni. Tymczasem ryzyko wystąpienia awarii technicznych w przypadku elektrowni wiatrowych jest znacznie mniejsze niż w przypadku innych typów elektrowni. Uwzględniając powyższe, Wnioskodawca II stwierdził, że rozwiązanie przyjęte w art. 3 pkt 3 prawa budowlanego jest nieproporcjonalne do celu założonego przez ustawodawcę. Wskazał ponadto, że nie występuje ważny interes publiczny przemawiający za ograniczeniem swobody działalności gospodarczej w zakresie budowy i eksploatacji elektrowni wiatrowych w porównaniu $\mathrm{z}$ innymi rodzajami elektrowni. Za wprowadzeniem powyższego ograniczenia nie przemawia także żadna $\mathrm{z}$ wartości, wymienionych w art. 31 ust. 3 Konstytucji.

Na tym tle Wnioskodawca II wniósł o stwierdzenie niezgodności art. 3 pkt 3, art. 82 ust. 3 pkt 5b prawa budowlanego i wiersza XXIX załącznika do tej ustawy, w brzmieniu nadanym przez ustawę o inwestycjach, $\mathrm{z}$ art. 2, art. 20, art. 22, art. 31 ust. 3 oraz art. 32 ust. 1 Konstytucji.

\section{- 2. Wzorce kontroli}

Analiza wzorców kontroli obejmujących art. 2, art. 20, art. 22, art. 31 ust. 3 oraz art. 32 ust. 1 Konstytucji została przedstawiona w pkt III.2 i pkt VI.2 stanowiska.

\section{- 3. Ocena formalnoprawna}

Wątpliwości Wnioskodawcy II o odniesieniu do zaskarżonych przepisów związane są z poddaniem przez ustawodawcę nadzorowi budowlanemu całości elektrowni wiatrowej. O ile przed wejściem w życie ustawy o inwestycjach nadzór budowlany obejmował jedynie części budowlane elektrowni, o tyle na gruncie tej ustawy zostały nim objęte także urządzenia techniczne elektrowni, takie jak generator, wirnik, przekładnia itp. Zdaniem Wnioskodawcy II jest to regulacja szczególna na tle innych rodzajów elektrowni, gdzie nadzorowi budowlanemu podlegają wyłącznie obiekty budowlane, a nie infrastruktura techniczna.

Kwestionowane przez Wnioskodawcę II art. 3 pkt 3 prawa budowlanego oraz wiersz XXIX zawarty w załączniku do tej ustawy zostały zmienione w następstwie wejścia $\mathrm{w}$ życie ustawy zmieniającej. W aktualnym stanie prawnym przepisy te mają następujące brzmienie:

- art. 3 pkt 3 prawa budowlanego:

„Ilekroć w ustawie jest mowa o: [...] budowli - należy przez to rozumieć każdy obiekt budowlany niebędący budynkiem lub obiektem małej architektury, jak: [...] części budowlane urządzeń technicznych (kotłów, pieców przemysłowych, elektrowni jądrowych, elektrowni wiatrowych i innych urządzeń) oraz fundamenty pod maszyny i urządzenia, jako odrębne pod względem technicznym części przedmiotów składających się na całość użytkową",

- wiersz XXIX załącznika do prawa budowlanego: 


\begin{tabular}{|l|c|c|c|c|c|}
\hline \multicolumn{2}{|c|}{} & \multicolumn{4}{|c|}{$\begin{array}{c}\text { Współczynnik wielkości obiektu (w) } \\
\text { (wysokośc w m) }\end{array}$} \\
\cline { 3 - 6 } & $\mathbf{5 2 0}$ & $\mathbf{2 0 - 5 0}$ & $\mathbf{2 5 0 - 1 0 0}$ & $>\mathbf{1 0 0}$ \\
\hline $\begin{array}{l}\text { Kategoria XXIX - wolno stojące } \\
\text { kominy i maszty oraz elektrownie } \\
\text { wiatrowe }\end{array}$ & 10,0 & 1,0 & 1,5 & 2,0 & 2,5 \\
\hline
\end{tabular}

Analiza treści powyższych przepisów dowodzi, że ustawodawca poprzez zmiany wprowadzone ustawą zmieniającą powrócił do ich brzmienia sprzed wejścia w życie ustawy o inwestycjach. W konsekwencji należy przyjąć, że art. 3 pkt 3 prawa budowlanego i wiersz XXIX załącznika do tej ustawy w brzmieniu zaskarżonym przez Wnioskodawcę II utraciły moc prawną, zaś postępowanie $\mathrm{w}$ tym zakresie podlega umorzeniu ze względu na niedopuszczalność wydania wyroku. $\mathrm{Z}$ tego względu jedynym przepisem, z którym może zostać powiązany zarzut Wnioskodawcy II, pozostaje art. 82 ust. 3 pkt $5 \mathrm{~b}$ prawa budowlanego.

Zgodnie z art. 82 ust. 3 pkt 5b prawa budowlanego wojewoda jest organem administracji architektoniczno-budowlanej pierwszej instancji $\mathrm{w}$ sprawach obiektów i robót budowlanych w zakresie elektrowni wiatrowych, w rozumieniu art. 2 pkt 1 ustawy o inwestycjach. Powyższy przepis ma zatem charakter kompetencyjny, wskazując organy administracji architektoniczno-budowlanej (tj. wojewodę) właściwe w sprawach obiektów i robót budowlanych w zakresie elektrowni wiatrowych. Kwestionowana regulacja nie wyznacza natomiast zakresu, w jakim nadzór ten jest sprawowany. W tym ostatnim aspekcie powołany przepis ma charakter blankietowy, odsyłając do art. 2 pkt 1 ustawy o inwestycjach.

Uwzględniając powyższe, należy podnieść dwie okoliczności, które - każda samodzielnie - przesądzają o braku podstaw do rozpatrzenia zarzutu Wnioskodawcy II w odniesieniu do art. 82 ust. 3 pkt $5 \mathrm{~b}$ prawa budowlanego. Po pierwsze, Wnioskodawca II zaskarżył ten przepis w zakresie, w jakim wyznaczono w nim zakres nadzoru budowlanego sprawowanego $\mathrm{w}$ stosunku do elektrowni wiatrowych. Materia ta nie jest jednak objęta regulacją kwestionowanego przepisu. Jak już wskazano, ma on wyłącznie charakter kompetencyjny i nie dotyczy zakresu nadzoru $\mathrm{w}$ stosunku do elektrowni wiatrowych. Żaden z argumentów powołanych przez Wnioskodawcę II nie odnosi się do spraw regulowanych w tym przepisie, a więc określania organów administracji architektoniczno-budowlanej w sprawach elektrowni wiatrowych. W konsekwencji brak jest podstaw do poddania merytorycznej ocenie art. 82 ust. 3 pkt $5 \mathrm{~b}$ prawa budowlanego w kontekście powyższego zarzutu, a postępowanie w tym zakresie powinno podlegać umorzeniu.

Po drugie, nawet jeżeli rozpatrywać zarzut Wnioskodawcy II, posiłkując się odesłaniem zawartym w art. 82 ust. 3 pkt 5 b prawa budowlanego i w konsekwencji poddać kontroli konstytucyjności także art. 2 pkt 1 ustawy o inwestycjach, do którego odsyła art. 82 ust. 3 pkt $5 \mathrm{~b}$ prawa budowlanego, to także w tym zakresie nastąpiła zmiana stanu prawnego w porównaniu ze stanem prawnym obowiązującym w chwili wystąpienia z wnioskiem II. Otóż art. 3 pkt 1 ustawy zmieniającej 
nadał nowe brzmienie art. 2 pkt 1 ustawy o inwestycjach. Tym samym przepis ten, w brzmieniu obowiązującym na dzień zainicjowania niniejszego postępowania, utracił moc prawną. Z uwagi jednak, że kontrolą konstytucyjności objęty jest nominalnie wyłącznie przepis zaskarżony przez Wnioskodawcę II, tj. art. 82 ust. 3 pkt 5b prawa budowlanego, który nadal obowiązuje w brzmieniu zakwestionowanym we wniosku, okoliczność wskazująca na konieczność umorzenia ze względu na utratę mocy prawnej ma charakter akcesoryjny i nie odnosi się wprost do przepisu poddanego kontroli.

$\mathrm{Na}$ marginesie warto zwrócić uwagę, że Wnioskodawca II nie przedstawił bliższego uzasadnienia dla zarzutu związanego z poddaniem całej elektrowni wiatrowej - jako obiektu budowlanego - nadzorowi budowlanemu. Ograniczył się w tym względzie do stwierdzenia, że funkcjonowanie elektrowni wiatrowych jest znacznie bardziej bezpieczne - w aspekcie ryzyka wystąpienia ewentualnych katastrof technicznych i zakresu powstałych w ich następstwie szkód - niż funkcjonowanie elektrowni konwencjonalnych oraz elektrowni atomowych. Powyższe stwierdzenie nie odnosi się jednak do zagadnienia, jakie względy przemawiają za niekonstytucyjnością regulacji przewidującej poddanie nadzorowi budowlanemu części technicznych elektrowni wiatrowych. Jedyny argument, który został podniesiony na tym tle, związany jest z nierównym traktowaniem podmiotów podobnych, jakimi zdaniem Wnioskodawcy II są przedsiębiorcy prowadzący działalność w zakresie elektrowni wiatrowych, elektrowni konwencjonalnych oraz elektrowni atomowych (które nota bene w Polsce nie funkcjonują). Wnioskodawca II nie wyjaśnił jednak w żaden sposób, jakie cechy - poza przeznaczeniem tych obiektów, tj. wytwarzaniem energii elektrycznej - nakazywałyby traktować je jako podmioty podobne.

Trzeba także odnieść się do stanowiska, które zdaje się przyjmować Wnioskodawca II, że w pojęciu budowli, o którym mowa w art. 3 pkt 3 prawa budowlanego, mieszczą się wyłącznie obiekty o stricte budowlanym charakterze, niezawierające elementów technicznych. Otóż w świetle powyższego przepisu do kategorii budowli ustawodawca zaliczył m.in. takie obiekty, jak lotniska, oczyszczalnie ścieków, stacje uzdatniania wody. Nie budzi wątpliwości, że na te obiekty składają się zarówno elementy stricte budowlane, jak i techniczne. Jeszcze inny charakter mają wolno stojące instalacje przemysłowe lub urządzenia techniczne, które w całości są elementami technicznymi, bez elementów budowlanych. Mimo to ustawodawca zaliczył je na gruncie art. 3 pkt prawa budowalnego expressis verbis do kategorii budowli. Należy stwierdzić, że ustawodawcy przysługuje daleko idąca swoboda w ustalaniu zakresu znaczeniowego pojęcia budowli, jak i zaliczaniu do niego określonych kategorii obiektów budowlanych. Zarzuty sformułowane we wniosku związane są z celowością oraz zasadnością dokonania określonej klasyfikacji przez ustawodawcę, materie te nie znajdują jednak oparcia w przepisach konstytucyjnych. Stąd też sprawa dopuszczalności poddania elektrowni wiatrowych nadzorowi budowlanemu, co najmniej uwzględniając 
treść powołanych przez wnioskodawcę zarzutów, nie może być uznana za stanowiącą przedmiot regulacji konstytucyjnej.

\section{Bibliografia}

Banaszak B., Konstytucja Rzeczypospolitej Polskiej. Komentarz, Warszawa 2012.

Dębowska-Romanowska T., Istota i treść władztwa finansowego [w:] Konstytucja, ustrój, system finansowy państwa. Księga pamiątkowa ku czci prof. Natalii Gajl, Warszawa 1999.

Garlicki L., Komentarz do art. 5 [w:] Konstytucja Rzeczypospolitej Polskiej. Komentarz, t. I, red. L. Garlicki, M. Zubik, Warszawa 2016.

Garlicki L., Polskie prawo konstytucyjne. Zarys wykładu, Warszawa 2012.

Komentarz do art. 63 [w:] Ustawa o planowaniu i zagospodarowaniu przestrzennym, red. M.J. Nowak, 2012, Legalis.

Komentarz do art. 63 ustawy o planowaniu i zagospodarowaniu przestrzennym, red. Z. Niewiadomski, 2018, Legalis.

Ofiarski Z., Źródła prawa podatkowego i jego stanowienie oraz podstawowe formy [w:] System prawa finansowego, t. 3, Prawo daninowe, red. L. Etel, Warszawa 2010.

Oniszczuk J., Podatki i inne daniny w orzecznictwie Trybunału Konstytucyjnego, Warszawa 2001.

Sarnecki P., Komentarz do art. 5 i 10 [w:] Konstytucja Rzeczypospolitej Polskiej. Komentarz, t. I, red. L. Garlicki, M. Zubik, Warszawa 2016.

Sokolewicz W., Komentarz do art. 217 [w:] Konstytucja Rzeczypospolitej Polskiej. Komentarz, t. IV, red. L. Garlicki, Warszawa 2005.

Sokolewicz W., Zubik M., Komentarz do art. 2 [w:] Konstytucja Rzeczypospolitej Polskiej. Komentarz, t. I, red. L. Garlicki, M. Zubik, Warszawa 2016.

Stelmasiak J., Geneza prawnego pojęcia „środowisko” jako przedmiotu ochrony prawnej [w:] Państwo, prawo, myśl prawnicza. Prace dedykowane profesorowi Grzegorzowi Leopoldowi Seidlerowi w dziewięćdziesiątą rocznicę urodzin, red. A. Korobowicz, L. Leszczyński, A. Pieniążek, M. Stefaniuk, Lublin 2003. 